\title{
Estimation of Groundwater Recharge at Pahute Mesa using the Chloride Mass-Balance Method
}

\author{
Prepared by \\ submitted to \\ Nevada Field Office \\ National Nuclear Security Administration \\ U.S. Department of Energy \\ Las Vegas, Nevada
}

Clay A. Cooper, Ronald L. Hershey, John M. Healey, and Brad F. Lyles

July 2013

Publication No. 45251 
Reference herein to any specific commercial product, process, or service by trade name, trademark, manufacturer, or otherwise, does not necessarily constitute or imply its endorsement, recommendation, or favoring by the United States Government or any agency thereof or its contractors or subcontractors.

Available for sale to the public from:

U.S. Department of Commerce

National Technical Information Service

5301 Shawnee Road

Alexandria, VA 22312

Phone: 800.553.6847

Fax: 703.605.6900

Email: orders@ntis.gov

Online ordering: http://www.osti.gov/ordering.htm

Available electronically at http://www.osti.gov/bridge.

Available for a processing fee to the U.S. Department of Energy and its contractors, in paper, from:

U.S. Department of Energy

Office of Scientific and Technical Information

P.O. Box 62

Oak Ridge, TN 37831-0062

Phone: 865.576.8401

Fax: 865.576.5728

Email: reports@adonis.osti.gov 


\title{
Estimation of Groundwater Recharge at Pahute Mesa using the Chloride Mass-Balance Method
}

\author{
prepared by \\ Clay A. Cooper, Ronald L. Hershey, John M. Healey, and Brad F. Lyles \\ Division of Hydrologic Sciences, Desert Research Institute \\ Nevada System of Higher Education
}

Publication No. 45251

submitted to

Nevada Field Office

National Nuclear Security Administration

U.S. Department of Energy

Las Vegas, Nevada

July 2013

The work upon which this report is based was supported by the U.S. Department of Energy under Contract \#DE-NA0000939. Approved for public release; further dissemination unlimited. 
THIS PAGE INTENTIONALLY LEFT BLANK 


\section{ABSTRACT}

Groundwater recharge on Pahute Mesa was estimated using the chloride mass-balance (CMB) method. This method relies on the conservative properties of chloride to trace its movement from the atmosphere as dry- and wet-deposition through the soil zone and ultimately to the saturated zone. Typically, the CMB method assumes no mixing of groundwater with different chloride concentrations; however, because groundwater is thought to flow into Pahute Mesa from valleys north of Pahute Mesa, groundwater flow rates (i.e., underflow) and chloride concentrations from Kawich Valley and Gold Flat were carefully considered. Precipitation was measured with bulk and tipping-bucket precipitation gauges installed for this study at six sites on Pahute Mesa. These data, along with historical precipitation amounts from gauges on Pahute Mesa and estimates from the PRISM model, were evaluated to estimate mean annual precipitation. Chloride deposition from the atmosphere was estimated by analyzing quarterly samples of wet- and dry-deposition for chloride in the bulk gauges and evaluating chloride wetdeposition amounts measured at other locations by the National Atmospheric Deposition Program. Mean chloride concentrations in groundwater were estimated using data from the UGTA Geochemistry Database, data from other reports, and data from samples collected from emplacement boreholes for this study. Calculations were conducted assuming both no underflow and underflow from Kawich Valley and Gold Flat. Model results estimate recharge to be $30 \mathrm{~mm} / \mathrm{yr}$ with a standard deviation of $18 \mathrm{~mm} / \mathrm{yr}$ on Pahute Mesa, for elevations $>1800 \mathrm{~m}$ amsl. These estimates assume Pahute Mesa recharge mixes completely with underflow from Kawich Valley and Gold Flat. The model assumes that precipitation, chloride concentration in bulk deposition, underflow and its chloride concentration, have been constant over the length of time of recharge. 


\section{ACKNOWLEDGMENTS}

We appreciate the insightful comments of Chuck Russell, Jenny Chapman, Karl Pohlmann, Steve Mizell, Greg Pohll, Rina Schumer, Ed Kwicklis, and Dan Levitt, which greatly improved this report. We also appreciate the contributions of Cheryl Collins who helped with GIS-aspects of the work in addition to generating maps and figures and Karen LeFebre for assisting in installation of the precipitation gauges and field data collection. This work was funded by the U.S. Department of Energy under contract no. DE-NA0000939. 


\section{CONTENTS}

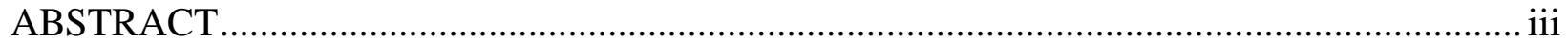

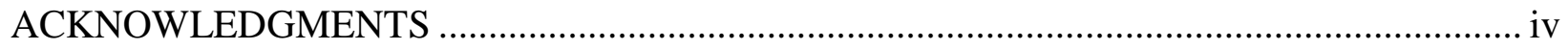

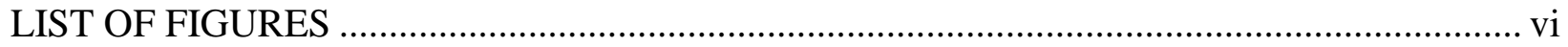

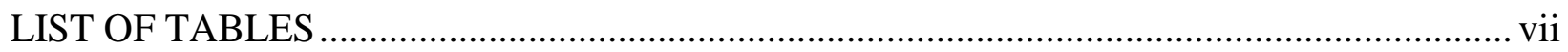

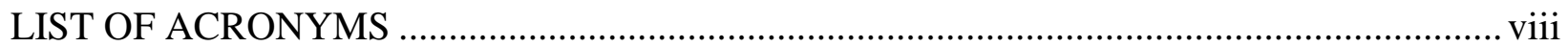

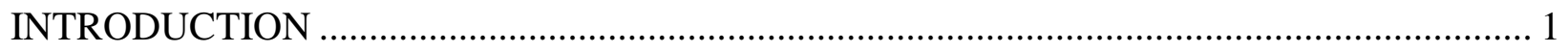

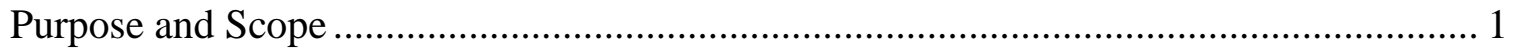

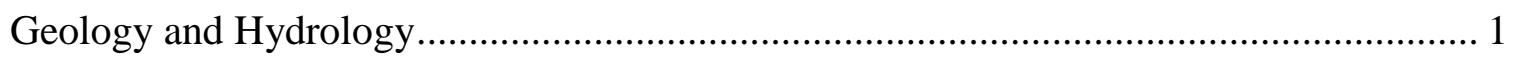

CHLORIDE MASS-BALANCE METHOD …..................................................................... 5

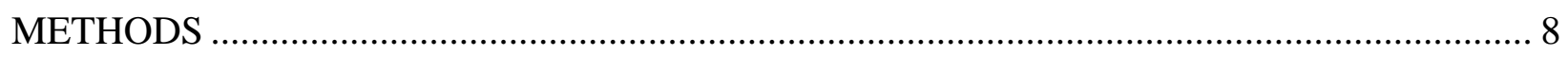

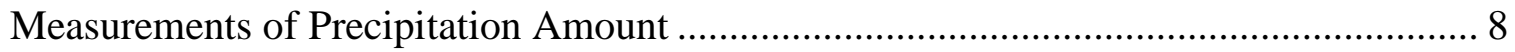

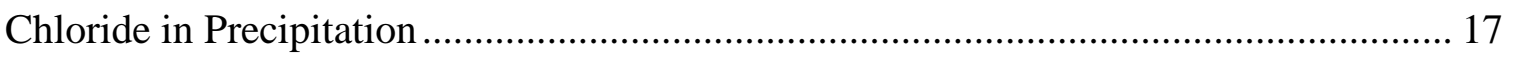

Chloride in Pahute Mesa Groundwater......................................................................... 24

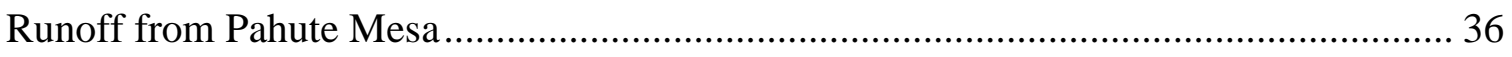

Underflow to Pahute Mesa........................................................................................... 36

Chloride Concentration of Underflow from Kawich Valley ........................................ 37

Chloride Concentration of Underflow from Gold Flat ................................................ 38

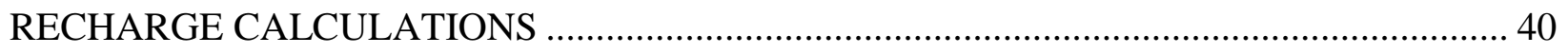

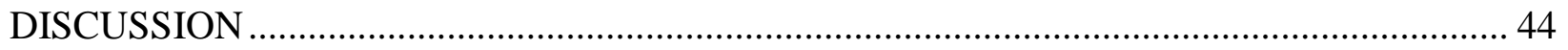

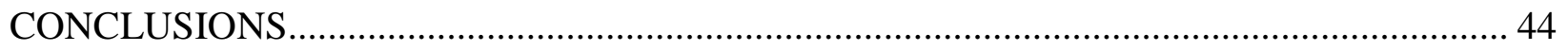

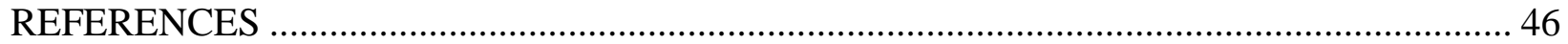

APPENDIX A. Chloride, Sulfate, and Isotopic Data. ....................................................... 52

APPENDIX B. Emplacement Borehole Chemical and Isotopic Data...................................... 64

APPENDIX C. Review and Evaluation of Rainier Mesa Chloride Data for a Chloride Mass-

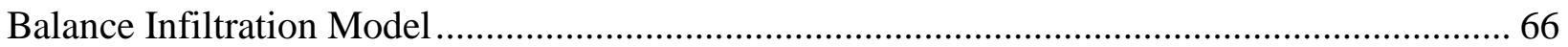




\section{LIST OF FIGURES}

1. Location of Pahute Mesa, six sites instrumented for this study, and three historical

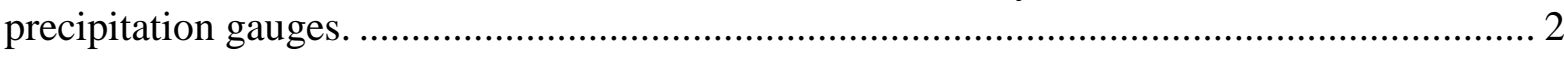

2. Precipitation recorded at each of the six sites for this study............................................ 10

3. Comparison between monthly precipitation at PM1 and A-20 ...................................... 13

4. Comparison of mean annual precipitation by year for PM1 and A-20 .............................. 13

5. Monthly precipitation at the two gauges located near the Sagebrush site, for the overlapping years 1987 through 2008........................................................................... 14

6. Comparison of mean annual precipitation among PM1 and A-20, located near the

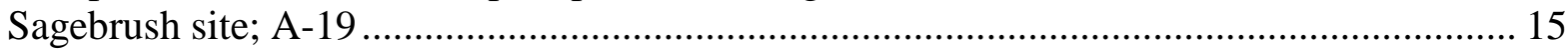

7. Comparison among monthly mean precipitation recorded the historical gauges PM1 and A-20 located near the Sagebrush Site, A-19 located near the Dead Horse Flat Site, and the 11-month records measured for this study........................................................ 15

8. Mean annual precipitation at each location based on PRISM. ............................................ 16

9. Precipitation-weighted seasonal mean of chloride concentration in precipitation collected at Great Basin National Park, Nevada, from 1985 through 2011...................................... 18

10. Precipitation-weighted seasonal mean chloride concentration plotted for each year (open

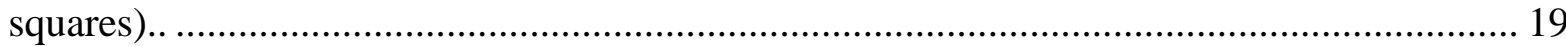

11. Chloride concentration in precipitation for the U.S. (from the National Atmospheric Deposition Program)......................................................................... 19

12. Time series of chloride in precipitation at each of the six sites. ......................................... 22

13. Mean chloride in bulk precipitation gauges at the six sites, between April 27, 2011 and March 27, 2012.

14. Location of wells on Pahute Mesa with water samples that are representative of groundwater and that were evaluated for use in the chloride mass-balance model............... 25

15. Average chloride concentrations in groundwater from wells on Pahute Mesa, in mg/L....... 27

16. Average sulfate concentrations in groundwater from wells on Pahute Mesa, in mg/L. ......... 28

17. Variation in chloride concentration with isotopic signature for four emplacement

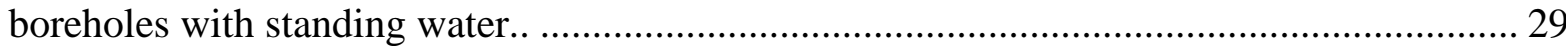

18. Isotopic signature of four emplacement boreholes with standing water in relation to the local meteoric water line (LMWL; $\delta^{2} \mathrm{H}=7.1 \delta^{18} \mathrm{O}-2.7$; Thomas et al., 2002).

19. Stable isotopic data for Rainier Mesa precipitation and tunnel portal gas-seal plug and

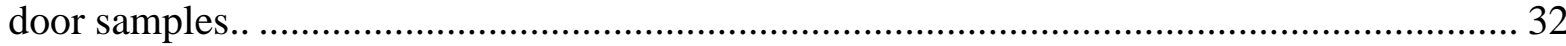

20. Location of springs at the NNSS sampled for this project.............................................. 33 
21. Isotopic signature of NNSS springs; the local meteoric water line (LMWL; $\delta^{2} \mathrm{H}=7.1 \delta^{18} \mathrm{O}$ 2.7; Thomas et al., 2002) and the global meteoric water line (GMWL; $\delta^{2} \mathrm{H}=8 \delta^{18} \mathrm{O}+$ 10; Craig, 1961) are shown for reference. ................................................................. 34

23. Average stable isotopic composition of springs in the Kawich Range............................... 39

24. Frequency histogram of annual precipitation at the (a) Sagebrush and (b) Dead Horse

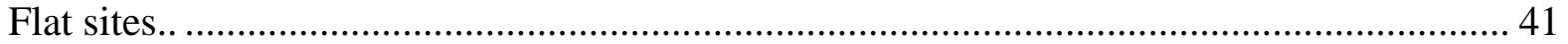

25. Outline of area higher than 1,800 m elevation amsl at Pahute Mesa................................... 42

26. Distribution of recharge at (a) the Sagebrush site (between $1800 \mathrm{~m}$ and $2000 \mathrm{~m}$ amsl), and (b) Dead Horse Flat site (>2000 m) from Monte Carlo calculations.

\section{LIST OF TABLES}

1. Annual estimates of underflow from Kawich Valley to Pahute Mesa and Gold Flat to Pahute Mesa by various authors. ........................................................................... 5

2. Location of the six sites instrumented with meteorological stations. .................................. 8

3. Comparison of precipitation amount recorded from the bulk gauge and tipping bucket

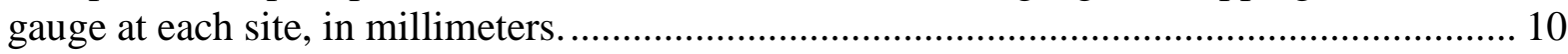

4. Annual precipitation at PM1 and A-20 near the Sagebrush site, and A-19 near Dead

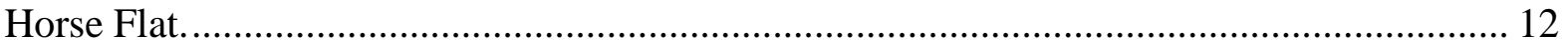

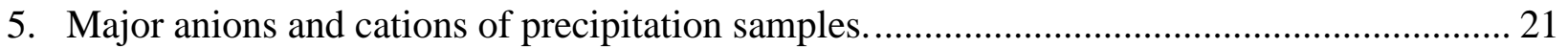

6. Chloride concentrations and isotopic signatures in groundwater from wells and emplacement boreholes in Pahute Mesa....................................................................... 26

7. Average chloride, sulfate, $\delta^{2} \mathrm{H}$, and $\delta^{18} \mathrm{O}$ with standard deviation for wells used to represent groundwater east of the Purse Fault in Pahute Mesa. 30

8. Average SIsotope Data for Rainier Mesa Tunnel Portal Gas-Seal Doors and Plugs samples.

9. Average chloride concentrations, $\delta^{2} \mathrm{H}$, and $\delta^{18} \mathrm{O}$ in springs in the Kawich Range................ 38

10. Average chloride concentration and isotopic signatures for wells in Gold Flat................... 39

11. Mean, standard deviation, and distribution of all input values used in calculations...........40 


\section{LIST OF ACRONYMS}

AT Ammonia Tanks

BB Buckboard Mesa

CAIP Corrective Action Investigation Plan

CMB Chloride Mass Balance

DHF Dead Horse Flat

ET Evapotranspiration

GBNP Great Basin National Park

NADP National Atmospheric Deposition Program

ND No data

NNSS Nevada National Security Site

NTS Nevada Test Site

PJ Pinyon-Juniper

PRISM Parameter-elevation Regression on Independent Slopes Model

SB Sagebrush

SC Silent Canyon

UGTA Underground Test Area 


\section{INTRODUCTION}

\section{Purpose and Scope}

The purpose of this report is to document the results of a study to estimate groundwater recharge from precipitation to Pahute Mesa, an elevated plateau located approximately $160 \mathrm{~km}$ northwest of Las Vegas, Nevada on the Nevada National Security Site (NNSS) (Figure 1). The Phase II Corrective Action Investigation Plan (CAIP) (U.S. Department of Energy, 2009) for central and western Pahute Mesa identified groundwater recharge as a model input that added significant uncertainty to the Phase I Pahute Mesa groundwater flow (Stoller-Navarro, 2006) and transport models (Stoller-Navarro, 2009). To support Phase II modeling, the chloride massbalance (CMB) method was used to estimate groundwater recharge, the results of which will be used to calibrate an infiltration model (INFIL3.0: U.S. Geological Survey, 2008) for Pahute Mesa. A separate report on the results of the infiltration model will be prepared by Los Alamos National Laboratory.

The scope of this study included evaluation of historical data and data collected for this task, construction of a CMB model of Pahute Mesa, and estimation of groundwater recharge amount using the Pahute Mesa CMB model with associated uncertainties. Historical data evaluated included precipitation data from Pahute Mesa, groundwater chemical and isotopic data, and groundwater underflow estimates from valleys north of Pahute Mesa. New data were generated from six precipitation monitoring stations installed on Pahute Mesa for this task and collection of water samples from four emplacement boreholes. Precipitation monitoring stations were installed at different elevations, which included both tipping bucket precipitation gauges and bulk precipitation collectors; bulk precipitation samples were analyzed for chemical constituent concentrations and isotopic signatures. Water samples from emplacement boreholes were collected by bailing and were analyzed for chemical constituent concentrations and isotopic signatures. The CMB model was constructed considering precipitation amount, spatial distribution of precipitation amount, elevation differences in precipitation amount, the chloride mass of dry fall and wet fall, chloride concentration in groundwater in Pahute Mesa, chloride concentration in groundwater flowing into Pahute Mesa from Kawich Valley and Gold Flat, the volume of underflow from these valleys, and the chloride concentration and volume of surfacewater runoff. These data were input into the CMB model producing estimates of groundwater recharge to Pahute Mesa; uncertainty of each input parameter was defined and used to quantify the uncertainty of the final recharge estimates.

\section{Geology and Hydrology}

Pahute Mesa is an elevated plateau of about 500 square kilometers $\left(\mathrm{km}^{2}\right)$ (StollerNavarro, 2006) approximately 160 km northwest of Las Vegas, Nevada (Drellack et al., 2002). Pahute Mesa ranges in elevation from 1,676 meters (m) above sea level to over 2,134 m (StollerNavarro, 2006; Blankennagel and Weir, 1973). The geology of the Pahute Mesa area is complex, encompassing at least six Tertiary-age calderas with normal faults, thrust faults, and intrusive bodies (Drellack et al., 2002). All rocks that are currently known to underlie Pahute Mesa are volcanic (Stoller-Navarro, 2006) with the total thickness of volcanic rocks approaching $5 \mathrm{~km}$ (Stoller-Navarro, 2006; Ferguson et al., 1994). These rocks are grouped into four volcanic hydrogeologic units based on lithology and secondary alteration; these are lava-flow aquifers, welded-tuff aquifers, vitric-tuff aquifers, and tuff confining units (Stoller-Navarro, 2006). At 
least a part of the upper saturated zone is an unconfined (phreatic) aquifer (Fenelon, et al., 2010). Groundwater in Pahute Mesa generally flows in a southwesterly direction (Fenelon, et al., 2010) primarily through fractures in vitric and welded tuff aquifers (Stoller-Navarro, 2006) toward Oasis Valley. Zeolitized bedded and nonwelded tuffs act as confining units that inhibit groundwater flow (Stoller-Navarro, 2006).

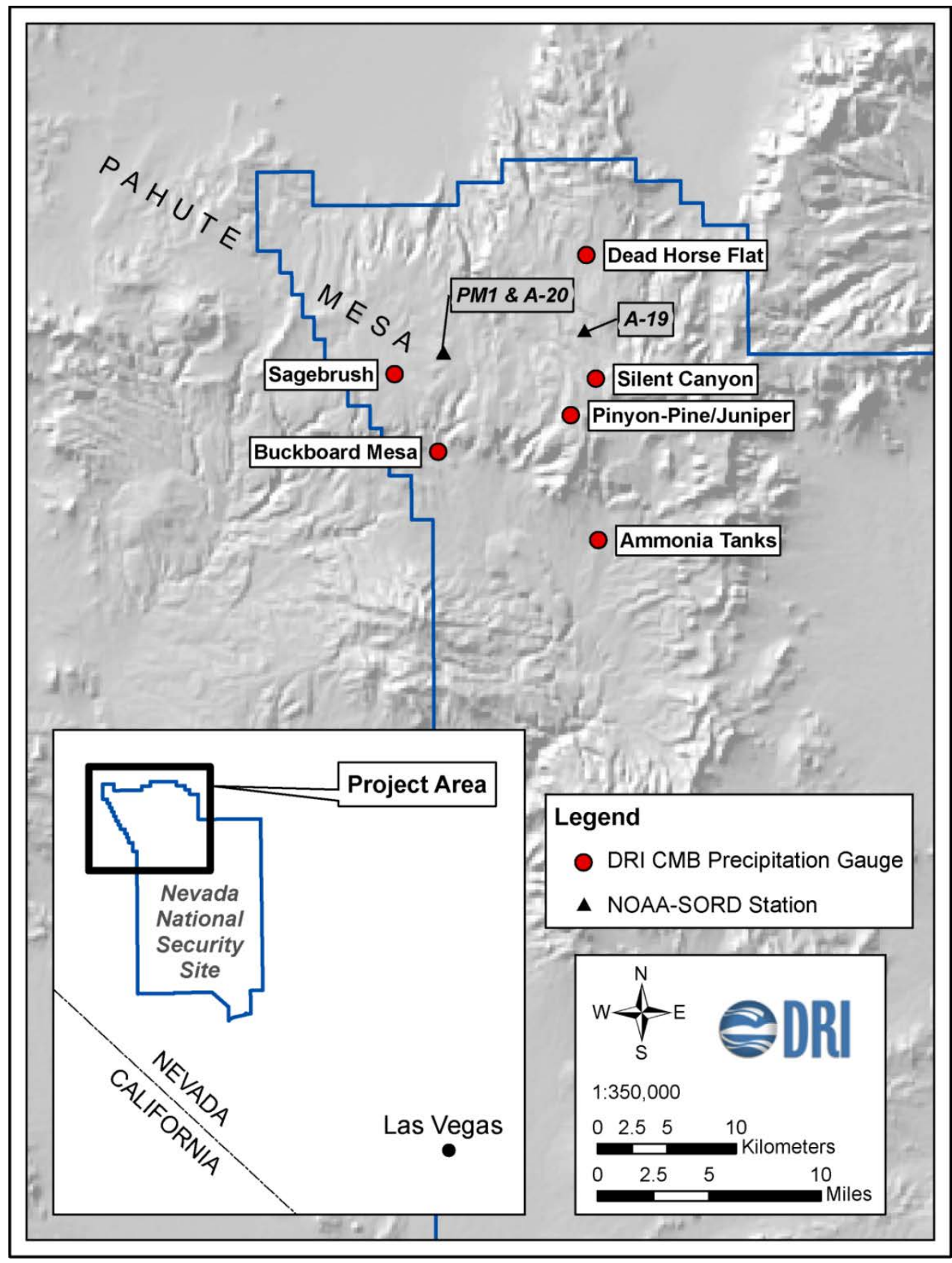

Figure 1. Location of Pahute Mesa, six sites instrumented for this study, and three historical precipitation gauges. 
Groundwater recharge to Pahute Mesa occurs from precipitation and underflow from areas north of Pahute Mesa (Stoller-Navarro, 2006). Precipitation infiltrates downward, primarily through joints and fractures (Laczniak et al., 1996). Based on measurements in packed-off zones in wells, groundwater flow is predominantly horizontal with a small component of downward flow in eastern Pahute Mesa and a small component of upward flow in western Pahute Mesa (Area 20) (Blankennagel and Weir, 1973). As recharging water moves downward, it encounters lower permeability rocks creating perched water (Laczniak et al., 1996); however these perched zones do not intersect the ground surface as there are no springs found on Pahute Mesa. The depth of the unsaturated zone on Pahute Mesa is greater than $610 \mathrm{~m}$ (Drellack et al., 2002); ultimately, perched water drains slowly through the unsaturated zone to recharge groundwater. Blankennagel and Weir (1973) estimated recharge for Pahute Mesa and Rainier Mesa as $3.9 \times 10^{6} \mathrm{~m}^{3} /$ year. They also estimated underflow from Kawich Valley and Gold Flat (north of Pahute Mesa) into Pahute Mesa as 6.8 x $10^{6} \mathrm{~m}^{3} / \mathrm{yr}$.

\section{Groundwater Recharge}

At least one of six processes has to occur to precipitation after it falls to the ground: precipitation can (1) evaporate, (2) transpire through plant stomata, (3) runoff over the land surface, or (4) infiltrate and (5) possibly recharge an underlying phreatic aquifer. If precipitation falls as snow, some of the snow will (6) sublimate while the remaining eventually melts and infiltrates below the snow pack, or run off through rivulets and small channels. These processes are complex and interrelated as they can happen simultaneously in a given location, or sequentially in space, and operate over timescales from minutes to years. For example, precipitation can infiltrate a few centimeters into the land surface and evaporate before it can become recharge, or it can runoff and later infiltrate into the soil, at which point it can be subject to evapotranspiration (ET) or recharge. Precipitation can percolate beyond a depth where it is susceptible to ET, but may require tens to hundreds, if not thousands, of years to reach the water table and become recharge.

Groundwater recharge is the entry of water into the saturated zone across the water table. It differs from infiltration, which is water that flows downward from the land-atmosphere boundary, but is still subjected to ET while it remains within the root zone. Net infiltration is water that passes below the zone of active ET that has not reached the saturated zone. The location where infiltration becomes net infiltration is at least several meters below the land surface (depending upon the depth of plant roots) and is the point where there is zero ET. This location is a function of depth to the saturated zone, root depth, hydraulic conductivity, soil moisture content and its relationship to soil-water tension, and the vertical hydraulic gradient in the unsaturated zone.

Accurate determination of groundwater recharge is one of the most difficult measurements to make in subsurface hydrology. Since recharge is a process and not a parameter, there is currently no way to make a direct measurement. Instead, recharge is often relegated to being a residual value of a mass-balance equation where the other terms are estimated, which can be problematic for several reasons. The first is that uncertainty in measured precipitation rates is equivalent to, or exceeds, estimated rates of inferred infiltration. The second problem is that measured values can vary greatly over space and time, resulting in equivalent spatial and temporal variance in infiltration and recharge, even if heterogeneity in other parameters is ignored. 
The classic, and perhaps oldest, method of determining recharge in the Great Basin is the empirical Maxey-Eakin method (Maxey and Eakin, 1949), which scales recharge as a percentage of precipitation within specific precipitation zones. The result is an empirical power-law relationship between precipitation and recharge. Similar empirical methods have used separate regression equations for other basins in Arizona and Nevada (e.g., Anderson et al., 1992; Maurer and Berger, 1997).

Other recharge methods are based on the measurement of hydraulic properties and identification of processes affecting the flow of surface water. Since there is no appreciable runoff at Pahute Mesa, these methods - stream gauging; geophysics; and the application of heat, chemical, and/or isotopic tracers - have limited (or no) applicability. The situation is similar for unsaturated zone methods. Although the unsaturated zone at Pahute Mesa is hundreds of meters deep, there is little soil development, and much of it consists of surface-exposed fractures. Welldeveloped soils tend to smooth out hydraulic properties compared to exposed fractures whose hydraulic properties and flow processes are largely unknown. Unsaturated zone approaches include the use of lysimeters, soil hydrodynamics (i.e., Darcy's law and the Richards equation), environmental tracers $\left({ }^{36} \mathrm{Cl}\right.$, chloride, and heat), and the calibration of numerical models to existing data.

The first estimate of recharge at Pahute Mesa was by Rush (1970). In a reconnaissance study of the Nevada Test Site (NTS, now the NNSS), Rush used the Maxey-Eakin method to estimate recharge to be one percent of the precipitation for the entire west Pahute Mesa area. This is an average for all precipitation zones (i.e., elevations in the Maxey-Eakin formulation). For the Buckboard Mesa area, above 2,134 m (6,000 ft), Rush estimated recharge to be 7 percent of total precipitation, or $2.35 \mathrm{~cm}$ (his estimate of annual precipitation was $335 \mathrm{~mm}$ [13.2 inches]).

In addition to recharge on Pahute Mesa, groundwater also flows from northern basins through Pahute Mesa. Blankennagel and Weir (1973) and Belcher and Sweetkind (2010) suggest that groundwater flow beneath Pahute Mesa originates from the northern areas of Kawich Valley and Gold Flat. Blankennagel and Weir (1973) estimated that potential recharge to Kawich Valley may be as great as $4.32 \times 10^{6} \mathrm{~m}^{3} / \mathrm{yr}$ while recharge to Gold Flat is estimated as $1.97 \times 10^{6} \mathrm{~m}^{3} / \mathrm{yr}$. Groundwater flow into Kawich Valley is estimated as $1.23 \times 10^{6} \mathrm{~m}^{3} / \mathrm{yr}$ while groundwater flow into Gold Flat is estimated as $2.46 \times 10^{6} \mathrm{~m}^{3} / \mathrm{yr}$ (Blankennagel and Weir, 1973). Blankennagel and Weir (1973) estimated that one-third of groundwater exiting Gold Flat flows beneath Pahute Mesa $\left(1.48 \times 10^{6} \mathrm{~m}^{3} / \mathrm{yr}\right)$, while most of the groundwater from Kawich Valley flows beneath Pahute Mesa $\left(5.55 \times 10^{6} \mathrm{~m}^{3} / \mathrm{yr}\right)$. The first estimate of flow from Kawich Valley to Pahute Mesa and Gold Flat to Pahute Mesa using a mixing model was conducted by Feeney et al. (1987) who developed a deuterium-calibrated steady-state mixing model of the western NNSS; they estimated that $2.5 \times 10^{6} \mathrm{~m}^{3} / \mathrm{yr}$ of groundwater flows from Kawich Valley to Pahute Mesa and Gold Flat to Pahute Mesa (Table 1). A larger deuterium-calibrated model that included areas surrounding the NNSS estimated that a much larger amount of groundwater, $8.29 \times 10^{6} \mathrm{~m}^{3} / \mathrm{yr}$, flows from Kawich Valley to Pahute Mesa and that $2.86 \times 10^{6} \mathrm{~m}^{3} / \mathrm{yr}$ flows from Gold Flat to Pahute Mesa (Sadler et al., 1992). Using a mixing-cell model with ${ }^{14} \mathrm{C}$ as a tracer, Spencer (1990) estimated underflow from Kawich Valley to Pahute Mesa and Gold Flat to Pahute Mesa each as $1.65 \times 10^{6} \mathrm{~m}^{3} / \mathrm{yr}$. More recent mixing-cell models by Calhoun (2000) and Carroll et al. (2007, 2008) did not discriminate between Pahute Mesa and Kawich Valley such that groundwater underflow from Kawich Valley and Gold Flat into Pahute Mesa could not be 
differentiated. Numerical flow models by Belcher and Sweetkind (2010) also did not discriminate between flows into, or out of, Pahute Mesa. Table 1 presents published estimates of underflow from Kawich Valley and Gold Flat to Pahute Mesa.

Table 1. Annual estimates of underflow from Kawich Valley to Pahute Mesa and Gold Flat to Pahute Mesa by various authors.

\begin{tabular}{lll}
\hline $\begin{array}{l}\text { Flow rate from Kawich } \\
\text { to Pahute Mesa } \\
\mathrm{m}^{3} / \mathrm{yr}\end{array}$ & $\begin{array}{l}\text { Flow rate from Gold Flat to } \\
\text { Pahute Mesa } \\
\mathrm{m}^{3} / \mathrm{yr}\end{array}$ & Source \\
\hline $4.32 \times 10^{6}$ & $4.32 \times 10^{6}$ & \\
$5.55 \times 10^{6}$ & $1.23 \times 10^{6}$ & Rush (1970) \\
$5.55 \times 10^{6}$ & $1.48 \times 10^{6}$ & Nevada State Engineer (1971) \\
$2.50 \times 10^{6}$ & $2.50 \times 10^{6}$ & Blankennagel and Weir (1973) \\
$1.65 \times 10^{6}$ & $1.65 \times 10^{6}$ & Feeney et al. (1987) \\
$8.29 \times 10^{6}$ & $2.86 \times 10^{6}$ & Spencer (1990) \\
\hline
\end{tabular}

\section{CHLORIDE MASS-BALANCE METHOD}

Recharge estimation methods based upon surface water processes and the unsaturated zone are poorly suited to Pahute Mesa and the Maxey-Eakin method is based upon correlations developed in other basins in Nevada. A more appropriate method would be one that uses measurements in the saturated zone, since this would filter daily and monthly fluctuations and reveal a long-term average, if one exists. The CMB method uses the tracer properties of a chlorine ion and tracks its mass balance between the atmosphere and groundwater. In the simplest sense - one-dimensional vertical flow through an unsaturated and saturated zone without ET and other chloride input - the concentration of dissolved chloride in an aquifer would be the same as the dissolved chloride concentration in precipitation recharging the aquifer. In real unsaturated zones where water both evaporates and transpires (chloride is highly soluble in water), chloride becomes concentrated in the pore water as it undergoes evaporation. Chloride is an essential micronutrient for plants, where it enters plants through roots, is stored in tissue, and eventually released back to the soil as biomass. Pore water that does not evaporate or transpire is infiltration (by definition) and eventually reaches the water table as recharge.

In the absence of runoff, the sum of recharge and ET is equal to precipitation. Areas where a smaller percentage of precipitation is recharged will result in higher chloride concentration in soil and groundwater because chloride is evapoconcentrated in the upper part of the unsaturated zone where evapotranspiration is active. Rain and snow evaporating from soil and water transpiring from plants will leave behind either solid chloride or chloride dissolved in un-evaporated pore water. Assuming that all of this chloride will eventually reach the saturated zone, recharge can be estimated if the ratio of the concentration of chloride in precipitation (i.e., rain and snow) to chloride in groundwater is known as is the amount of precipitation (rain and snow). The method can become hampered by the addition of chloride not associated with precipitation. Wind-blown or dry deposition of chloride can contribute more to the chloride input on the land surface than chloride associated with precipitation (also known as wet deposition). Although not strictly derived from precipitation, dry-deposition chloride can dissolve in soil water and, therefore, enter the aquifer through recharge. Chloride associated with dry deposition 
must be accounted for in the mass balance since it also dissolves in pore water and eventually enters the aquifer along with wet-deposition chloride. The best way to handle chloride associated with dry deposition is to include it with chloride in wet deposition since chloride from both sources eventually ends up in the aquifer ${ }^{1}$.

The crux of the CMB method is to track chloride mass in a system where all of the inputs and outputs are known, except for groundwater recharge. The input of chloride (as mass flux, $\mathrm{M} / \mathrm{L}^{2} / \mathrm{T}$ ) entering the unsaturated zone from precipitation is

$$
P C_{p}
$$

where $P$ is average annual precipitation $(\mathrm{L} / \mathrm{T})$ and $C_{p}$ is the chloride mass concentration in precipitation $\left(\mathrm{M} / \mathrm{L}^{3}\right)$. As discussed below, spatial variability of the chloride concentration in precipitation is poorly known, but away from coastal areas, is less than $0.5 \mathrm{mg} / \mathrm{L}$ in the U.S. (National Atmospheric Deposition Program; http://nadp.sws.uiuc.edu/; accessed 8/15/2012). The spatial variability of precipitation, however, is more problematic and can be highly variable (sometimes over distances as small as one kilometer) in the desert Southwest. In mass-balance calculations, input is matched by output, which is the mass flux of chloride either moving downward through the unsaturated zone below the depth of active ET or running off the land surface. That is, the output of chloride mass is

$$
R C_{r}+Q_{r o} C_{r o}
$$

where $R$ is groundwater recharge $(\mathrm{L} / \mathrm{T}), C_{r}$ is the concentration of chloride in groundwater recharge $\left(\mathrm{M} / \mathrm{L}^{3}\right), Q_{r o}$ is the amount of precipitation that runs off outside the basin as surface water either as sheet flow or through channels in the recharge area (volume per unit area per unit time, $\mathrm{L} / \mathrm{T}$ ), and $C_{r o}$ is the chloride concentration of runoff. On Pahute Mesa, there is little if any runoff, since precipitation mostly either evaporates, transpires, or infiltrates through soil and surface-exposed fractures. If runoff does occur, but eventually infiltrates within the recharge area, it is considered infiltration.

In contrast to little runoff from Pahute Mesa, there is appreciable groundwater underflow from Kawich Valley and Gold Flat (Blankennagel and Weir, 1973; Feeney, et al., 1987; Sadler et al., 1992). If Pahute Mesa recharge is assumed to mix completely with Kawich Valley and Gold Flat groundwater, an additional input term is required,

$$
\sum_{i=1}^{2} q_{g w_{i}} C_{g w_{i}}
$$

where $q_{g w}$ is the volumetric flux of groundwater $(\mathrm{L} / \mathrm{T})$ and $C_{g w}$ is its mean chloride concentration $\left(\mathrm{M} / \mathrm{L}^{3}\right)$, and the index (i) specifies from which valley underflow is derived.

The complete chloride mass-balance equation is established by equating input (1) and (3) with output (2),

$$
P C_{p}+\sum_{i=1}^{2} q_{g w_{i}} C_{g w_{i}}=R C_{r}+Q_{r o} C_{r o}
$$

\footnotetext{
${ }^{1}$ Another method would be to disregard chloride input associated with dry deposition, but then dry-deposition chloride must be subtracted from the total chloride mass in the aquifer. There are too many uncertainties, however, for a precise calculation.
} 
To implement the CMB method, four key assumptions must be addressed (Eriksson and Khunakasem, 1969; Dettinger, 1989; Wilson and Guan, 2004). The first is that the only source of chloride is from precipitation, i.e., there are no other sources of chloride in groundwater. This is a problem in the southern Great Basin, since it is recognized that perhaps as much as 30 percent of chloride mass in phreatic aquifers is from chloride deposited on the land surface as dry fallout (Dettinger, 1989; Tyler et al., 1996). This additional source of chloride is included in the model through measurements of chloride concentration in combined precipitation and dry fallout. Some chloride may have been added to groundwater within Pahute Mesa from groundwater flow derived from Kawich Valley and Gold Flat. These sources are also included in the model.

The second assumption that must be addressed to implement the CMB method is that chloride is inert and does not undergo chemical reactions between the soil, rocks, and pore water. Water-rock reactions that might add chloride to Pahute Mesa groundwater are considered in the model. Chloride can also accumulate in plants, but the significance is neither well understood nor quantified on a landscape scale and is assumed to be negligible in the mass balance.

The third assumption is that the chloride deposition rate and precipitation rate have been constant during the residence time of groundwater where it is being sampled. The last major climate shift was at the end of the Pleistocene 12,000 years before present. Precipitation (and presumably recharge) were greater during the Pleistocene; if the groundwater sampled had undergone higher recharge rates in the past, then the CMB would overestimate present-day recharge. The hydrologic and climate systems are in disequilibrium because they operate on different time scales, and the uncertainty in precipitation patterns and annual amount is too great to warrant a time-dependent analysis of recharge, so a steady-state analysis was used.

The fourth assumption is that the measured chloride concentration in groundwater accurately reflects chloride concentration in groundwater from recharge. For example, as implemented, the CMB model assumes uniform chloride distribution on the land surface and in the aquifer. In addition to subsurface flow from Kawich Valley and Gold Flat, recharge may occur through surface-exposed fractures at areas of Pahute Mesa lacking soil development; net infiltration beneath these areas will have a different chloride concentration than beneath areas where soil development is more prevalent. Even when spatial variability of chloride and precipitation input is known, the model assumes that chloride in the aquifer is perfectly mixed.

One of the first studies on development of the CMB method was by Erikkson and Khunakasem (1969) who applied it to the northern coastal plain of Israel. They applied CMB to 13 transects (up to $40 \mathrm{~km}$ long) from the coast inland (i.e., transects were perpendicular to the coast), producing averaged results for each transect. There was a significant difference between chloride deposition near the coast and chloride deposition inland such that the chloride concentration of precipitation was integrated along each transect. Erikkson and Khunakasem also accounted for dry deposition of chloride, or chloride on the land surface not associated with precipitation. Dettinger (1989) applied the method to sixteen basins in Nevada and found that correlation coefficients for recharge efficiencies between CMB and two other methods were between 0.54 and 0.95. Russell and Minor (2002) modified the CMB method to account for elevation-dependent recharge and applied it to southern Nevada. They used measurements of discharge and chloride concentration in seventeen springs, with precipitation estimated from isohyetal maps, to determine recharge within the NNSS, the Thirsty Canyon drainage, and the area around Beatty, Nevada. A sensitivity study determined that uncertainty in recharge was primarily from uncertain recharge chloride concentrations, and secondarily to precipitation 
estimates. Russell et al. (2007) also employed an elevation-dependent chloride mass-balance method to estimate recharge in Steptoe Valley, Nevada. The chloride mass-balance method also has been used to estimate recharge in soils at the Hanford Nuclear Reservation (Gee et al., 2005). Instead of measuring chloride concentration in groundwater, they measured chloride in unsaturated zone pore water. In a comparison study with a 26-year record of lysimeter drainage, Gee et al. (2005) concluded that the CMB method applied in that manner may not reliably estimate recharge in systems where recharge is greater than a few millimeters per year.

The advantage of the CMB method is that it captures linear processes and integrates over the time-scale of recharge without the analyst having to know anything about that time scale. Important nonlinear processes and feedbacks that may occur on daily, or even seasonally (such as evaporation and condensation in the unsaturated zone, or vapor and liquid interactions), are assumed to be smoothed over the time-scale of recharge. By integrating over time, highfrequency fluctuations (e.g., those less than annual) in chloride input to the saturated zone are removed while the more-meaningful, long-term recharge signal is retained.

\section{METHODS}

This section describes the data selection process and begins with a discussion of precipitation amount on Pahute Mesa, chloride concentration in precipitation, chloride concentration in groundwater, and the manner in which the calculations are performed and how uncertainty is assessed.

\section{Measurements of Precipitation Amount}

Six sites were instrumented with bulk and tipping-bucket precipitation gauges in early 2011. The sites were selected to sample a range of elevations and vegetation types on Pahute Mesa. The six sites are labeled as Ammonia Tanks (AT), Buckboard Mesa (BM), Sagebrush (SB), Dead Horse Flat (DHF), Silent Canyon (SC), and Pinyon-Juniper (PJ) (Figure 1). The coordinates and elevation for each site are shown in Table 2.

Table 2. Location of the six sites instrumented with meteorological stations.

\begin{tabular}{llll}
\hline Site & Elevation, $\mathrm{m}$ & Latitude & Longitude \\
\hline Ammonia Tanks & 1610 & $37^{\circ} 8.00^{\prime}$ & $116^{\circ} 28.67$ \\
Buckboard Mesa & 1743 & $37^{\circ} 11.47^{\prime}$ & $116^{\circ} 26.44^{\prime}$ \\
Sagebrush & 1912 & $37^{\circ} 14.50^{\prime}$ & $116^{\circ} 28.54^{\prime}$ \\
Dead Horse Flat & 2054 & $37^{\circ} 19.11^{\prime}$ & $116^{\circ} 19.17^{\prime}$ \\
Silent Canyon & 2141 & $37^{\circ} 14.27^{\prime}$ & $116^{\circ} 18.74^{\prime}$ \\
Pinyon-Juniper & 2213 & $37^{\circ} 12.86^{\prime}$ & $116^{\circ} 19.98^{\prime}$ \\
\hline
\end{tabular}

An isohyetal map (PRISM) was also investigated for analysis. Ultimately, precipitation was estimated from historical precipitation gauges located on Pahute Mesa. All three methods are discussed below beginning with the measured bulk precipitation gauge data. 


\section{Bulk Precipitation Gauges at Each Site}

Each bulk precipitation gauge consisted of a stainless steel cylinder sealed at the bottom with a welded plate. The gauges were $3.05 \mathrm{~m}$ long $(10 \mathrm{ft})$ with an inside diameter of $21.3 \mathrm{~cm}$ (8.375 inch) and were set into the ground such that the top of the gauge was approximately $2.75 \mathrm{~m}$ above the land surface. Alter-shield wind screens were attached to the bulk gauges to minimize the formation of strong updrafts that can distort the trajectories of precipitation particles falling toward a gauge and to generate turbulent air motion over the gauge orifice to break up streamlines and improve catch. A removable screen was inserted inside each gauge to keep out debris; the screens were removed during the November site visit to allow snow fall to reach the bottom of the gauge. The gauges were installed in February and March 2011 and removed March 27, 2012.

Approximately a 2-cm thick layer of mineral oil was poured into the gauge to limit evaporation. Using a steel tape, the depth of the top of the oil was measured each month and the amount of precipitation was calculated as the difference in level between the current and previous month. At quarterly intervals, all of the liquid in the gauge was pumped out for chemical analysis, the gauge was refilled with mineral oil, and the depth to the top of the oil was measured. Precision of the depth measurements was within $\pm 1.5 \mathrm{~mm}( \pm 1 / 16$ inch).

Measurements were made during a 12-month period beginning with the first measurement on April 25 (the gauges were made operational on March 21). The data are presented in Table 3 along with measurements from the tipping bucket gauges (discussed below). Figure 2 presents precipitation graphically. The general trend in precipitation was between 10 and $40 \mathrm{~mm}$ of precipitation recorded each month in April and May of 2011, followed by several intense summer thunderstorms in August, and finally the beginning of several months of little precipitation (December, 2011 through March, 2012). Although the six instrumented sites differ by location, elevation, terrain, and topography, the monthly data show a similar annual trend, although there appears to be no relationship between precipitation amounts at each site for a given month. In other words, the order in precipitation amount (i.e., lowest to highest) between the sites on each date is variable. Using the six bulk gauges, the average annual precipitation within the study area was $189 \mathrm{~mm} / \mathrm{yr}$.

\section{Tipping Bucket Gauges at Each Site}

Each tipping bucket gauge measured precipitation in 30-minute intervals. Table 3 presents the values for the same time interval in which the bulk gauges were measured, so the two types of gauges can be compared directly. In general, but not strictly, the tipping bucket gauges systematically measured less precipitation than the bulk gauges. The reason for the underestimation (compared to bulk gauges) is in the measurement of snowfall. Tipping bucket gauges are poorly suited to measuring snowfall unless they are heated (the gauges used in this study were not) because a greater mass of snow needs to fall compared with rain to record a measurement (the density of a snowflake is approximately 10 percent of liquid water). The accumulated snow is subject to extended periods of sublimation that has the net effect of reducing measured precipitation. Average precipitation in the study area determined from the tipping bucket gauges is $146 \mathrm{~mm} / \mathrm{yr}$. 
Table 3. Comparison of precipitation amount recorded from the bulk gauge and tipping bucket gauge at each site, in millimeters. AT: Ammonia Tanks; BM: Buckboard Mesa; SB: Sagebrush; DHF: Dead Horse Flat; SC: Silent Canyon; and PJ: Pinyon-Juniper.

\begin{tabular}{|c|c|c|c|c|c|c|c|c|c|c|c|c|}
\hline \multirow[b]{2}{*}{ Date } & \multicolumn{2}{|c|}{ AT } & \multicolumn{2}{|c|}{ BM } & \multicolumn{2}{|c|}{ SB } & \multicolumn{2}{|c|}{ DHF } & \multicolumn{2}{|c|}{ SC } & \multicolumn{2}{|c|}{ PJ } \\
\hline & bulk & tip & bulk & tip & bulk & tip & bulk & tip & bulk & tip & bulk & tip \\
\hline $4 / 25 / 2011$ & 25.4 & 0.0 & 12.7 & 11.2 & 9.5 & 10.4 & 22.2 & 12.4 & 31.8 & 19.3 & 25.4 & 10.4 \\
\hline 5/31/2011 & 9.5 & 1.0 & 0.0 & 16.2 & 25.4 & 16.3 & 15.9 & 19.8 & 31.8 & 23.9 & 34.9 & 23.9 \\
\hline 6/29/2011 & 12.7 & 81.8 & 6.4 & 2.8 & 0.0 & 0.0 & 6.4 & 0.0 & 0.0 & 0.0 & 0.0 & 0.3 \\
\hline 8/2/2011 & 63.5 & 0.0 & 44.5 & 46.7 & 104.8 & 116.8 & 92.1 & 90.4 & 38.1 & 50.3 & 44.5 & 45.5 \\
\hline 9/8/2011 & 0.0 & 0.0 & 0.0 & 0.0 & 15.9 & 0.0 & 0.0 & 4.3 & 6.4 & 13.0 & 4.8 & 4.3 \\
\hline 10/17/2011 & 0.0 & 0.0 & 15.9 & 11.5 & 6.4 & 14.7 & 12.7 & 15.0 & 12.7 & 22.4 & 27.0 & 29.0 \\
\hline 11/15/1011 & 0.0 & 0.0 & 0.0 & 0.7 & 3.2 & 0.8 & 3.2 & 1.0 & 0.0 & 2.0 & 0.0 & 2.3 \\
\hline $12 / 15 / 2011$ & 3.2 & 0.0 & 4.8 & 1 . & 4.8 & 3.0 & 1.6 & 1.8 & 3.2 & 3. & 6.4 & 6.4 \\
\hline $1 / 17 / 2012$ & 1.6 & 0.0 & 1.6 & 0.5 & 1.6 & 0.0 & 3.2 & 0.0 & 4.8 & 0.0 & 0.0 & 0.0 \\
\hline 2/23/2012 & 15.9 & 4.6 & 15.9 & 7.3 & 33.3 & 9.9 & 30.2 & 7.9 & 39.7 & 21.1 & 42.9 & 1.7 \\
\hline 3/27/2012 & 15.9 & 0.0 & 22.2 & 13.2 & 17.5 & 14.2 & 31.8 & 14.5 & 28.6 & 20.8 & 41.3 & 25.1 \\
\hline Total & 7.6 & 7.4 & 3.8 & 111.2 & 222.2 & 186.2 & 219.1 & 167.1 & 196.8 & 176.3 & 227.0 & 148.7 \\
\hline
\end{tabular}

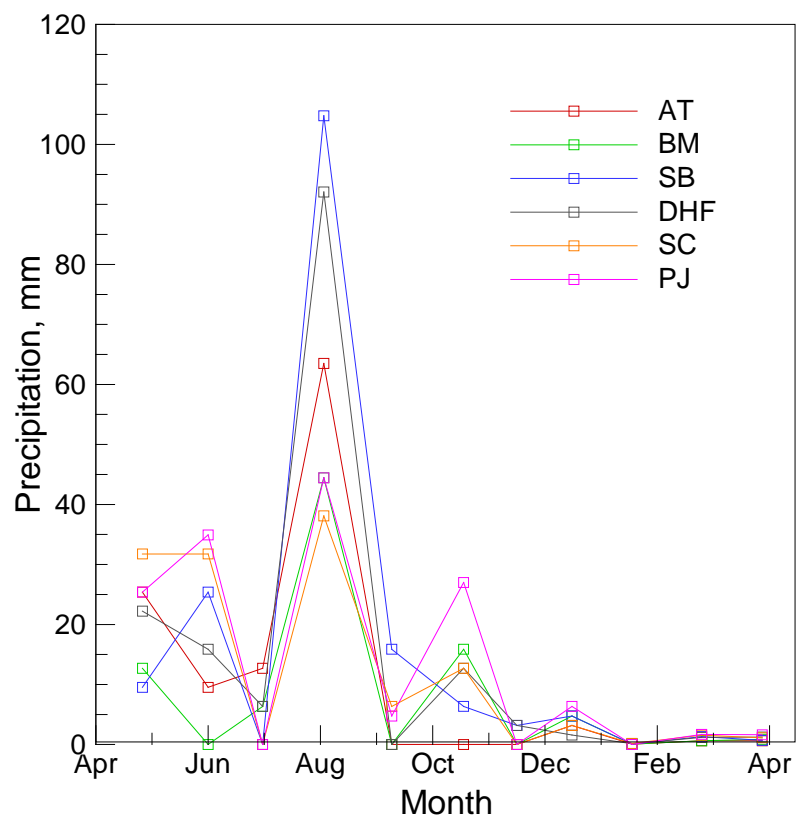

Figure 2. Precipitation recorded at each of the six sites for this study. Exact date of record is given in Table 3. AT: Ammonia Tanks; BM: Buckboard Mesa; SB: Sagebrush; DHF: Dead Horse Flat; SC: Silent Canyon; and PJ: Pinyon-Juniper. 
The original intent of the study was to measure one year's worth of data at each site and to use these data in the chloride mass-balance model. The problem is that without knowing mean annual precipitation at each site, there is no way of knowing if the data collected are representative of precipitation on Pahute Mesa. An analysis of long-term data recorded from three existing precipitation gauges on Pahute Mesa is discussed below and compared to the bulk and tipping bucket gauge results.

\section{Existing Gauges on Pahute Mesa: PM1, A-20, and A-19}

In addition to analyzing bulk and tipping bucket gauges, data from three historical precipitation gauges (PM1, A-20, and A-19) on Pahute Mesa were also used in the analysis. These data were determined to be more representative of the long-term mean than the short-term records of each of the six sites collected in 2011 and early 2012.

Long-term precipitation records exist for locations near the Sagebrush and Dead Horse Flat sites. Two precipitation gauges are located near the Sagebrush site (A-20 and PM1) and one gauge (A-19) is located near Dead Horse Flat (Figure 1). All gauges have been decommissioned and were operated by the Special Operations and Research Division of the National Oceanic and Atmospheric Administration (NOAA-SORD).

Precipitation gauge A-20 is located approximately three km east of the Sagebrush site, and gauge PM1 is located approximately $1 \mathrm{~km}$ northeast of A-20. Both gauges were universal weighing rain gauges and were decommissioned on September 14, 2011 (PM1) and October 1995 (A-19). The elevations of the A-20, PM1, and Sagebrush sites are 1,986 m, 1,998 m, and $1,912 \mathrm{~m}$ above sea level, respectively. Data for each site were collected monthly and the average annual values are presented in Table 4.

Mean annual precipitation at PM1 between 1964 and 2009 was $193.7 \mathrm{~mm}$ (46 years of monthly data). The mean annual precipitation at A-20 between 1987 and 2008 was $212.2 \mathrm{~mm}$ (22 years of data). The mean annual precipitation values at the two stations are remarkably similar considering that the monthly precipitation does not correlate well for the overlapping period (1987 through 2008) of the two gauges (Figure 3) and annual values do not correlate at all (Figure 4). The correlation coefficient of monthly precipitation between the two data sets is 0.57 , suggesting that the data are positively correlated, but that the values themselves are not well matched. Figure 5 shows that the two gauges sometimes recorded wildly varying monthly values even though the two gauges were separated by only $1 \mathrm{~km}$. In some cases (see late 1996, inset), the storm(s) were so localized that A-20 received more than $60 \mathrm{~mm}$ of precipitation in one month while PM1 received less than $10 \mathrm{~mm}$. 
Table 4. Annual precipitation at PM1 and A-20 near the Sagebrush site, and A-19 near Dead Horse Flat. Standard deviation is in the same units as precipitation, millimeters per year. Reliable precipitation measurements were not recorded at A-20 and A-19 until 1987. Blank records indicate years where no data were collected. The mean and standard deviation are based on a normal distribution.

\begin{tabular}{|c|c|c|c|c|c|c|c|}
\hline Year & PM1, mm & $\mathrm{A}-20, \mathrm{~mm}$ & $\mathrm{~A}-19, \mathrm{~mm}$ & Year & PM1, mm & $\mathrm{A}-20, \mathrm{~mm}$ & $\mathrm{~A}-19, \mathrm{~mm}$ \\
\hline 1964 & 129.6 & & & 1987 & 310.1 & 160.3 & 309.6 \\
\hline 1965 & 294.1 & & & 1988 & 187.5 & 264.7 & 276.6 \\
\hline 1966 & 130.8 & & & 1989 & 121.9 & 335.3 & 339.9 \\
\hline 1967 & 281.2 & & & 1990 & 195.1 & 180.1 & 215.6 \\
\hline 1968 & 146.3 & & & 1991 & 181.6 & 295.7 & 247.6 \\
\hline 1969 & 184.4 & & & 1992 & 206.0 & 229.1 & $53.6^{\mathrm{a}}$ \\
\hline 1970 & 126.0 & & & 1993 & 147.1 & 128.0 & \\
\hline 1971 & 164.6 & & & 1994 & 122.7 & 138.4 & 295.7 \\
\hline 1972 & 124.0 & & & 1995 & 178.3 & 164.1 & \\
\hline 1973 & 262.4 & & & 1996 & 176.8 & 248.7 & \\
\hline 1974 & 150.1 & & & 1997 & 180.6 & 118.1 & \\
\hline 1975 & 164.1 & & & 1998 & 367.8 & 353.6 & \\
\hline 1976 & 255.5 & & & 1999 & 237.7 & 178.1 & \\
\hline 1977 & 234.2 & & & 2000 & 210.1 & 464.6 & \\
\hline 1978 & 323.9 & & & 2001 & 190.0 & 383.6 & \\
\hline 1979 & 106.4 & & & 2002 & 66.8 & 106.2 & \\
\hline 1980 & 152.4 & & & 2003 & 175.8 & 186.9 & \\
\hline 1981 & 140.7 & & & 2004 & 203.2 & 192.5 & \\
\hline 1982 & 238.3 & & & 2005 & 205.7 & 95.5 & \\
\hline 1983 & 417.1 & & & 2006 & 195.1 & 201.9 & \\
\hline 1984 & 298.2 & & & 2007 & 185.2 & 128.0 & \\
\hline 1985 & 109.7 & & & 2008 & 116.3 & 114.8 & \\
\hline \multirow[t]{4}{*}{1986} & 153.9 & & & 2009 & 162.6 & & \\
\hline & & & & Mean & 193.7 & 212.2 & 280.8 \\
\hline & & & & $\begin{array}{l}\text { Stand. } \\
\text { Dev. }\end{array}$ & 72.3 & 101.9 & 44.5 \\
\hline & & & & $\begin{array}{l}\text { Stand. } \\
\text { Error }\end{array}$ & 10.5 & 21.7 & 18.2 \\
\hline
\end{tabular}

${ }^{\bar{a}}$ Mean and standard deviation for A-19 exclude data from 1992 because (1) the gauge showed no precipitation for February and March, although significant precipitation was recorded at PM1 and A20, and (2) the gauge clearly malfunctioned in 1993. If 1992 data are included, the mean and standard deviation of the A-19 data are $248.4 \mathrm{~mm}$ and $95.02 \mathrm{~mm}$, respectively. 


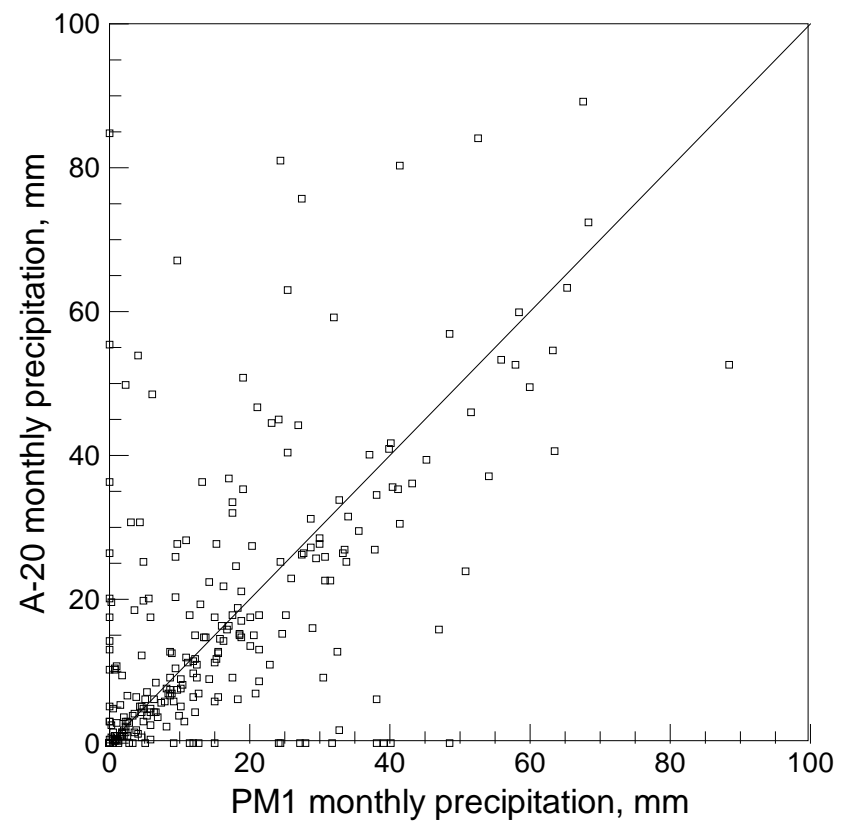

Figure 3. Comparison between monthly precipitation at PM1 and A-20. The correlation coefficient for the $1: 1$ line is 0.57 , suggesting some correlation in precipitation between the two gauges, which are located $1 \mathrm{~km}$ apart. The solid line depicts a one-to-one correlation between the two gauges.

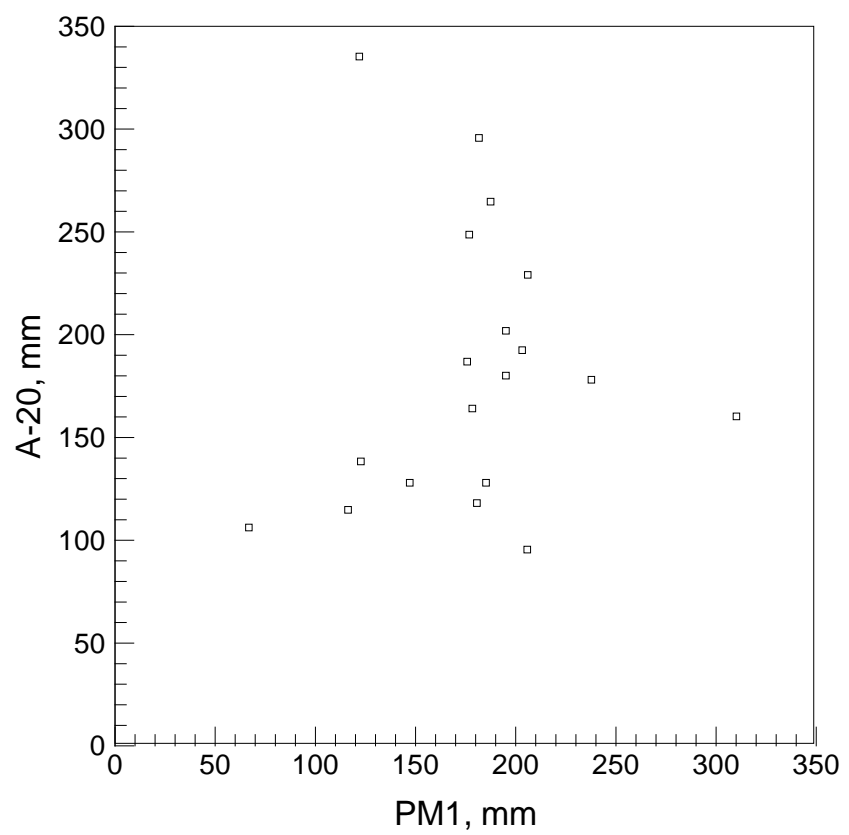

Figure 4. Comparison of mean annual precipitation by year for PM1 and A-20. 


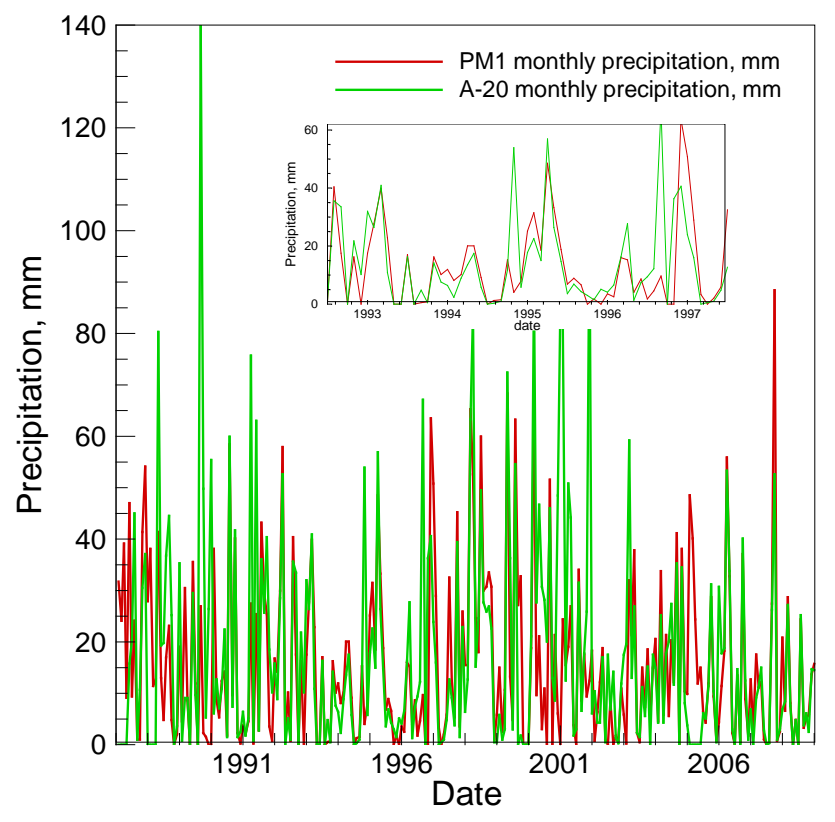

Figure 5. Monthly precipitation at the two gauges located near the Sagebrush site, for the overlapping years 1987 through 2008. The data are somewhat correlated for monthly precipitation amounts between 10 and $40 \mathrm{~mm}$, but correlation is poor for peaks and troughs. The inset shows the records for the period between June 1992 and June 1997.

Based upon historical data, there appears to be a significant difference between precipitation measured at gauges adjacent to the Sagebrush Site (1,912 m above sea level) versus those adjacent to the Dead Horse Flat site (2,054 m above sea level). Figure 6 compares mean annual precipitation at the three gauges (PM1, A-20, and A-19) and the annual record at each of the six sites (from Table 3). The mean of all precipitation measurements at PM1 and A-20 (i.e., for the Sagebrush Site) was $200 \pm 10 \mathrm{~mm} / \mathrm{yr}$ (standard deviation $82 \mathrm{~mm} / \mathrm{yr}$ ) while the mean for Dead Horse Flat (A-19) was $281 \pm 18.2 \mathrm{~mm} / \mathrm{yr}$ (standard deviation $45 \mathrm{~mm} / \mathrm{yr}$ ) . Standard error of the mean is defined as, $\Delta x=s / \sqrt{N}$, where $\Delta x$ is the standard error (mm/yr), $s$ is the standard deviation of the mean ( $\mathrm{mm} / \mathrm{yr})$, and $N$ is the number of data points used to calculate the mean. Precipitation measured at the Sagebrush site over the period spring 2011 through winter 2012 was similar to the historical mean at PM1 and A-20, but precipitation measured over the same 12-month period at Dead Horse Flat was $65 \mathrm{~mm}$ less than the mean for A-19. The Sagebrush precipitation data appear to indicate that the precipitation amount over the period was “average” while the Dead Horse Flat data suggest a below-average period of precipitation.

Figure 7 shows mean monthly rainfall trends on Pahute Mesa from January through December for the three gauges PM1, A-20 (near the Sagebrush Site), and A-19 (near Dead Horse Flat). Monthly mean values for PM1 and A-20 follow a similar trend with the values themselves within each other's uncertainty at a given time. Precipitation measured in the bulk gauges, however, is never representative of an average year. The precipitation trend from A-19 shows little relationship to the trend data from PM1 and A-20, although the data are sparser at A-19. 


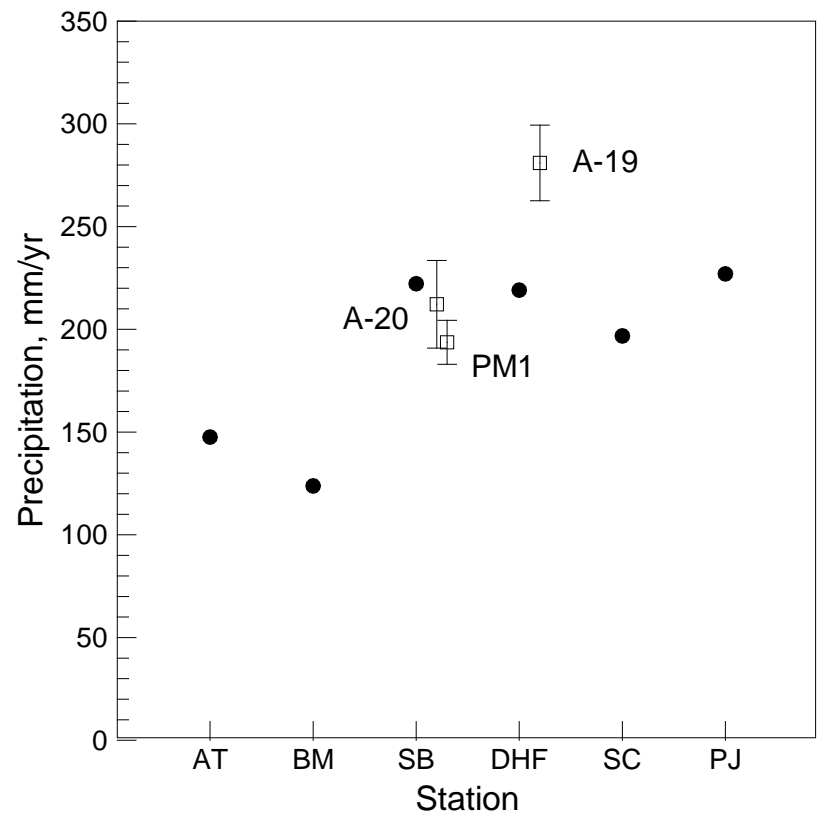

Figure 6. Comparison of mean annual precipitation among PM1 and A-20, located near the Sagebrush site; A-19, located near Dead Horse Flat; and precipitation measured at the six sites from March 21, 2011 and March 27, 2012. AT: Ammonia Tanks; BM: Buckboard Mesa; SB: Sagebrush; DHF: Dead Horse Flat; SC: Silent Canyon; and PJ: Pinyon-Juniper. A-20 and PM1 adjusted slightly to the right of the SB location for clarity.

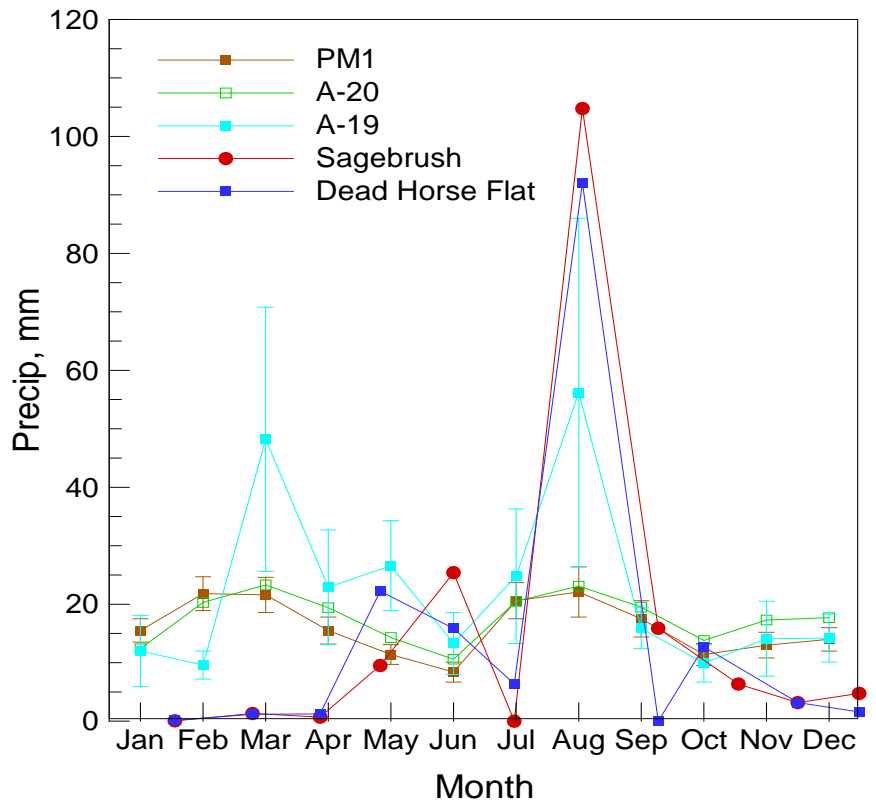

Figure 7. Comparison among monthly mean precipitation recorded at the historical gauges PM1 and A-20 located near the Sagebrush Site, A-19 located near the Dead Horse Flat Site, and the 11-month records measured for this study. 


\section{$\underline{\text { PRISM Estimates }}$}

The isohyetal map produced by the Parameter-elevation Regression on Independent Slopes Model (PRISM) (http://www.prism.oregonstate.edu/) was investigated to determine whether it was practical to estimate mean precipitation within the study area. PRISM uses regression to estimate precipitation by allowing the data at each station to be weighted depending upon the distance between stations, elevation, terrain, steepness, and topography. Precipitation on Pahute Mesa was estimated using PRISM by determining an average for the location of each of the six sites for this study (AT, BB, SB, etc.) and then calculating a mean for the six sites. Figure 8 shows average precipitation at each of the six sites based on PRISM between 1980 and 2011. The model predicts an increase in precipitation with elevation, which is expected, but except for Ammonia Tanks, there is considerable overlap in uncertainty among the stations. More importantly, the mean PRISM value estimated for the Sagebrush site (316 $\pm 18 \mathrm{~mm} / \mathrm{yr})$ is 50 percent greater than the value determined from the PM1 and A-20 gauges. Mean PRISMpredicted precipitation at the Dead Horse Flat site is $336 \pm 20 \mathrm{~mm} / \mathrm{yr}$ while the data from A-19 (although only seven years of record) is $254 \pm 22 \mathrm{~mm} / \mathrm{yr}$. The mean of all six PRISM estimates (i.e., the mean of each of the six sites instrumented for this study) is $321 \pm 43 \mathrm{~mm} / \mathrm{yr}$, which is significantly greater than the mean values determined by the bulk gauges and the historical data.

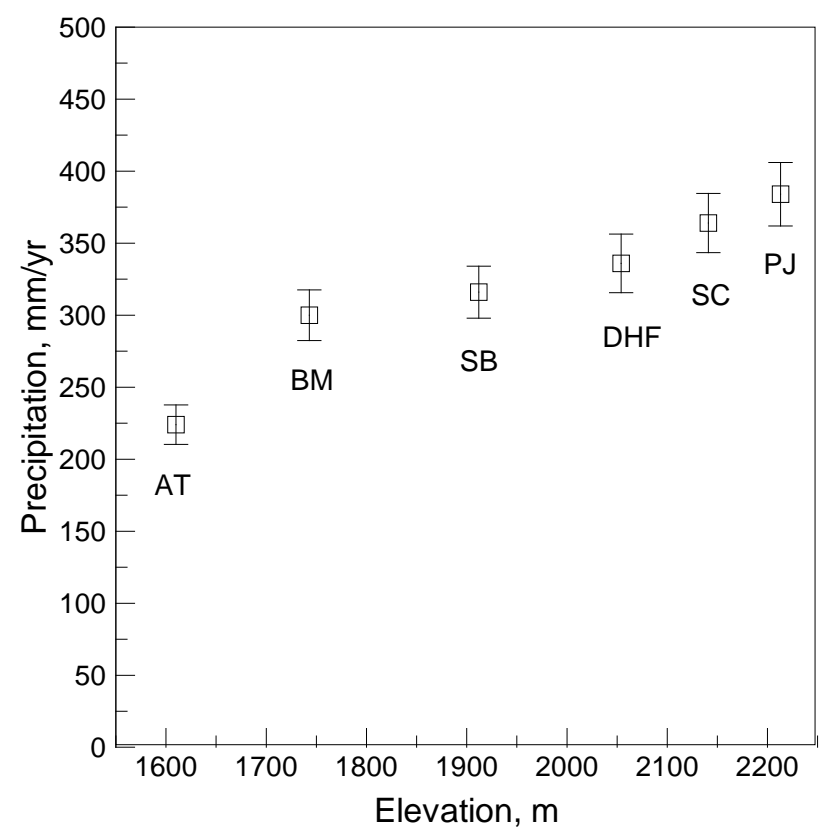

Figure 8. Mean annual precipitation at each location based on PRISM. Error bars denote standard error. AT: Ammonia Tanks; BM: Buckboard Mesa; SB: Sagebrush; DHF: Dead Horse Flat; SC: Silent Canyon; and PJ: Pinyon-Juniper. 


\section{Precipitation Amount Summary}

Precipitation on Pahute Mesa was estimated using bulk and tipping bucket gauges that were installed for this project, analyzing the record of three historical gauges located on the mesa, and using the PRISM model. The tipping bucket gauges resulted in the lowest estimates $(146 \mathrm{~mm} / \mathrm{yr})$ likely because they underestimate snowfall. The bulk gauges likely recorded accurately precipitation for the period between February 2011 and March 2012 (189 mm/yr), but the amount of precipitation was atypical of a 'normal' year, in comparison to the historical gauges located on the site. At the other extreme, the PRISM model estimated precipitation at the Sagebrush Site as $316 \pm 18 \mathrm{~mm} / \mathrm{yr}$ and at Dead Horse Flat as $336 \pm 20 \mathrm{~mm} / \mathrm{yr}$. This is troublesome because PRISM does not match the historical record at the two sites. Mean annual precipitation at PM1 was estimated as $193.7 \mathrm{~mm} / \mathrm{yr}$ and at A-20 is $212 \mathrm{~mm} / \mathrm{yr}$, and the average of all of the data from the two locations is $200 \pm 10 \mathrm{~mm} / \mathrm{yr}$. Mean annual precipitation recorded at gauge A-19 near Dead Horse Flat was $281 \pm 18.4 \mathrm{~mm} / \mathrm{yr}$. The PRISM model results in a precipitation estimate that is more than 50 percent greater than the mean historical record. The discrepancy is less at Dead Horse Flat where the PRISM estimate exceeds the historical data by 20 percent.

It appears that precipitation amount is best estimated using the historical data (PM1, A-20, and A-19) as it relies on long-term data collection. In contrast, PRISM is based partly on a model and the project only allowed for a single year of data collection. Additionally, the historical data show a difference in precipitation at Sagebrush and Dead Horse Flat, which allows for recharge to be estimated for two zones. Analysis of historical data, however, leaves some questions pertaining to actual precipitation behavior. That is, although they are separated by only one kilometer, the monthly values at PM1 and A-20 at the Sagebrush Site do not correlate well as is shown in Figures 3 and 5. The annual values do not correlate at all (Figure 4). However, the mean of the monthly values show a similar trend (Figure 7) even though the individual monthly values do not, which suggests that precipitation is highly spatially variable and somewhat random. Annual precipitation for the Sagebrush site is $200 \pm 10 \mathrm{~mm} / \mathrm{yr}$ (elevation $1912 \mathrm{~m}$ ) and $281 \pm 18.4 \mathrm{~mm} / \mathrm{yr}$ for Dead Horse Flat (elev. $2054 \mathrm{~m}$ ) are used in the recharge calculations.

\section{Chloride in Precipitation}

\section{Data from National Atmospheric Deposition Program}

The U.S. has established the National Atmospheric Deposition Program (NADP; http://nadp.sws.uiuc.edu/) to measure the chemistry of atmospheric deposition and its effects on the environment. The program began in 1978 and measures amounts of acids, nutrients, and base cations in precipitation. The data are collected weekly and reported as weighted averages per season. The seasons are defined as winter (December through February), spring (March through May), summer (June through August), and fall (September through November). Samples are collected only during precipitation events, which results in only negligible amounts of dry deposition measured.

The NADP evaluates the quality of data using four metrics. Criterion 1 is evaluated based on the percentage of the summary period for which there are valid samples (the definition of a valid sample is not provided). Criterion 2 evaluates the percentage of the summary period for which precipitation amounts are available either from the rain gauge or sample volume. Criterion 
3 evaluates the percentage of the total measured precipitation associated with valid samples. And, Criterion 4 evaluates collection efficiency, which is the sum of sample bucket depths during the summary period divided by the sum of the rain gauge amounts for all valid samples where both samples are available. All four criteria are reported as percentages and users must scrutinize the data for their intended purposes. For their own reports, NADP requires that criteria 1, 3, and 4 exceed 75 percent and criterion 2 exceeds 90 percent.

The nearest precipitation measurement station to Pahute Mesa is located at Great Basin National Park (GBNP) in Nevada at an elevation of 2,067 m above sea level (latitude 39.05; longitude 114.2158). Great Basin National Park is located approximately $275 \mathrm{~km}$ northeast of Pahute Mesa. A plot of all data, since measurements began in 1985, is shown in Figure 9. No discernible trend is apparent from the NADP data. The mean chloride concentration of all data is $0.16 \pm 0.011 \mathrm{mg} / \mathrm{L}$ (defined as standard error). If only data fulfilling the NADP requirements are evaluated, however, the mean is $0.16 \pm 0.014 \mathrm{mg} / \mathrm{L}$, identical to two significant figures with the whole data set. A plot of seasonal values is shown in Figure 10 and suggests that chloride concentration in the spring and summer is approximately $0.05 \mathrm{mg} / \mathrm{L}$ greater than the chloride concentration measured in the fall and winter.

In coastal areas, chloride concentration in precipitation is controlled by sea spray from the ocean. Inland, the controls are poorly known, since few studies have been undertaken, yielding limited data sets. In coastal areas, atmospheric chloride concentration in precipitation can be greater than $1 \mathrm{mg} / \mathrm{L}$ (Figure 11). The figure shows that chloride concentration in precipitation is under $0.5 \mathrm{mg} / \mathrm{L}$ at locations greater than several hundred kilometers from coastal areas. The contours in the figure are heavily biased by the sample locations, and as a result, show large parts of the west coast of the United States that lack data with lower chloride concentrations.

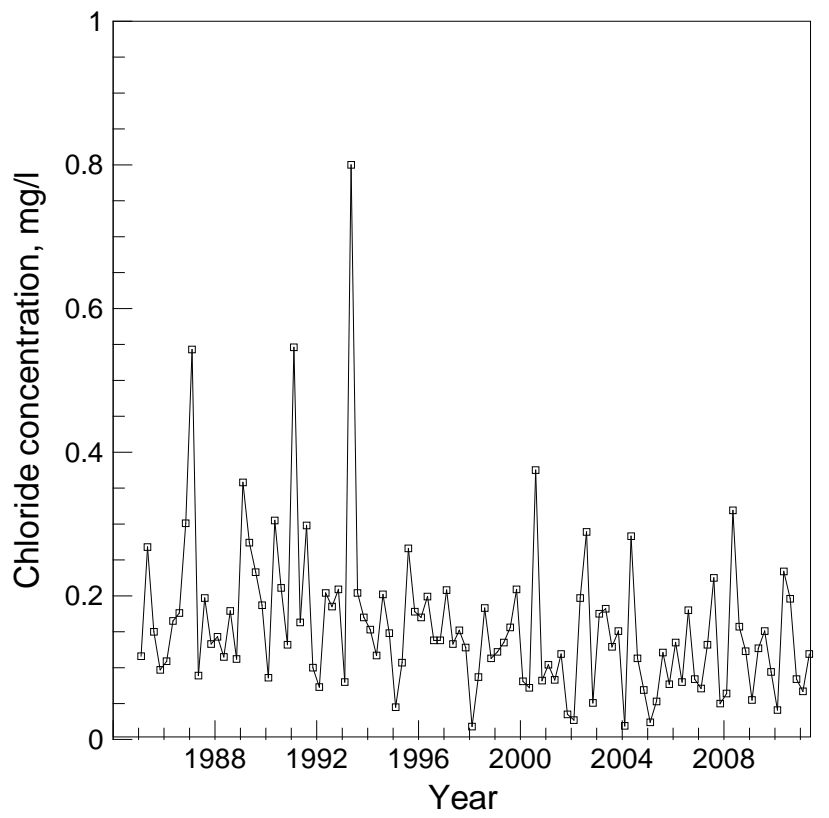

Figure 9. Precipitation-weighted seasonal mean of chloride concentration in precipitation collected at Great Basin National Park, Nevada, from 1985 through 2011. 


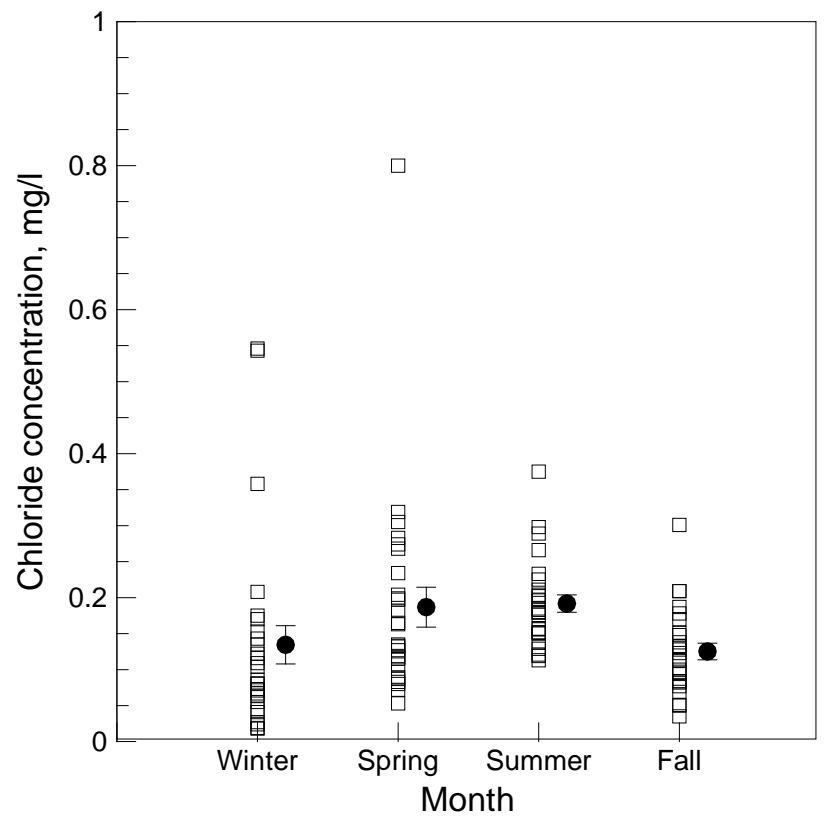

Figure 10. Precipitation-weighted seasonal mean chloride concentration plotted for each year (open squares). Mean chloride concentration for each season is plotted as a solid symbol, displaced slightly to the right of its proper location for clarity.

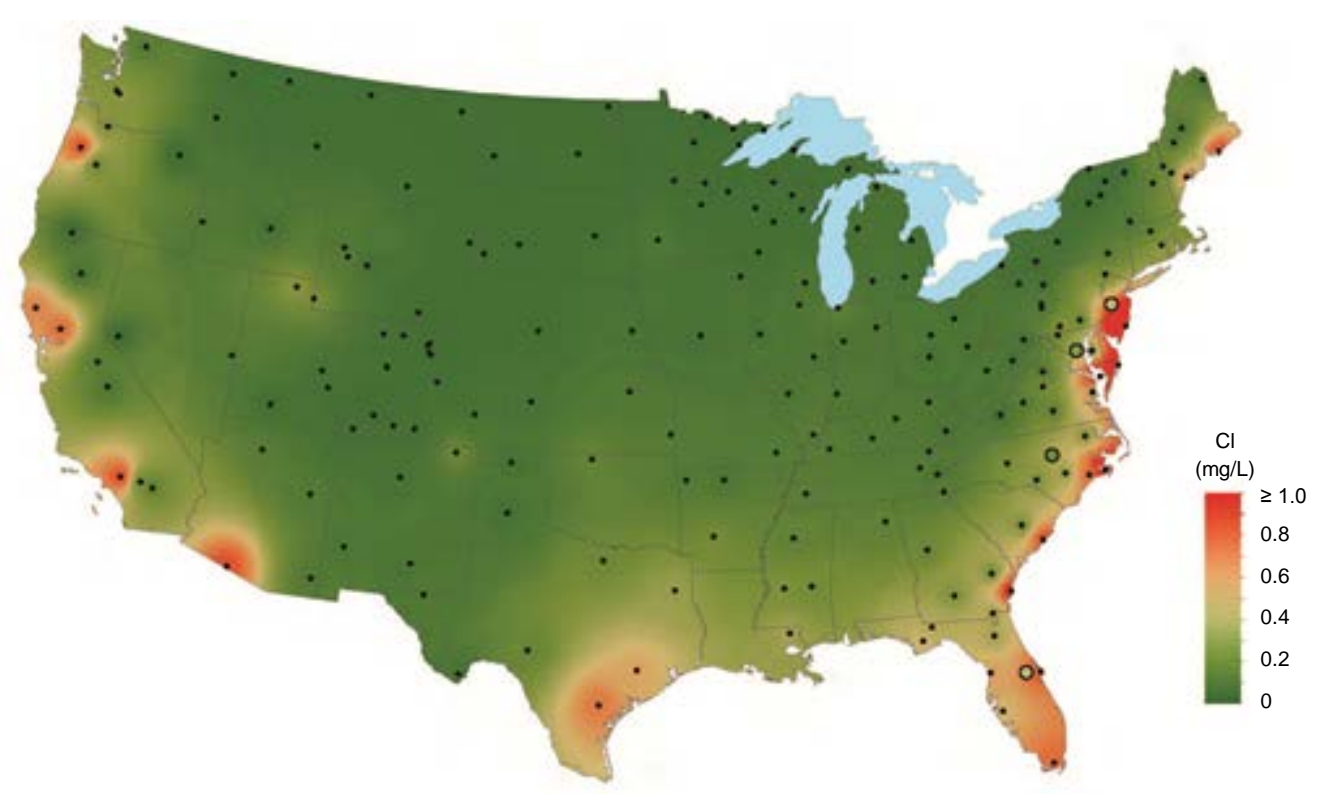

Figure 11. Chloride concentration in precipitation for the U.S. (from the National Atmospheric Deposition Program). On the west coast, contouring is particularly biased by sample location, since the mean of samples collected along the coast reports concentrations greater than $0.6 \mathrm{mg} / \mathrm{L}$, while the contoured values for coastal areas located away from sample locations are less than $0.2 \mathrm{mg} / \mathrm{L}$. 


\section{$\underline{\text { Bulk Precipitation Measurements of Chloride Concentration }}$}

Precipitation samples containing chloride derived from both dry- and wet-deposition were collected and analyzed quarterly from the bulk precipitation gauges at each of the six sites installed on Pahute Mesa for this study. Using a small electric pump, samples were collected from each bulk gauge and placed in Nalgene bottles for analysis of major ions and $30 \mathrm{~cm}^{3}$ vials with Polyseal caps for $\delta^{2} \mathrm{H}$ and $\delta^{18} \mathrm{O}$ analysis. The samples were kept in a cooler at approximately $4^{\circ} \mathrm{C}$ and transported to Desert Research Institute's Water Analysis Laboratory for major-ion determination and to the Nevada Isotope Laboratory at the University of Nevada, Reno for isotopic analysis. Standard UGTA chain-of-custody procedures were followed when transporting samples. The results of the major-ion analysis are presented in Table 5.

A time series of chloride values in in the bulk gauges is shown in Figure 12. Excluding the Ammonia Tanks values, chloride in precipitation was between 0.6 and $2.8 \mathrm{mg} / \mathrm{L}$. The Ammonia Tanks values were disregarded in the recharge analysis as the location was within $10 \mathrm{~m}$ of a dirt road with vehicular travel, which is thought to have stirred up dust and be the reason for the higher values (than all of the other samples) between September 2011 and March 2012. Although the data are limited, there is a slight increase in bulk chloride concentration at all sites in June 2011. The significance of the trend, however, is unknown and would require analysis of several years of samples to better determine if the trend exists.

With respect to annual mean chloride concentration in the bulk gauges, except for Buckboard Mesa and Ammonia Tanks (which is already discarded), chloride in the bulk gauges was nearly the same for all of the sites (Sagebrush, Dead Horse Flat, Silent Canyon, and PinyonJuniper) when uncertainty is considered (Figure 13). Chloride concentrations measured from the bulk precipitation samplers, however, are ten-to-twenty times higher than the precipitation measurements reported by the NADP indicating that the samples contain significant chloride derived from dry deposition. High chloride concentrations would be expected if the samples were subject to evaporation, but the layer of mineral oil on top of precipitation in the sampler prevented evaporation. Additionally, the $\mathrm{pH}$ of samples collected from the bulk gauges was between 6 and 7.5 for all samples (Table 5). The $\mathrm{pH}$ of rain is typically 5.3 assuming equilibrium of carbon dioxide between air and precipitation. Higher values of $\mathrm{pH}$ suggest that wind-blown dust, silt, and sand containing carbonate and chloride minerals was deposited in the samplers and dissolved in the water. 
Table 5. Major anions and cations of precipitation samples. No sample was collected from Buckboard Mesa or Pinyon-Juniper on January 17, 2011 because of freezing and plugging of mineral oil and water in the sample tube resulting in small sample volume.

\begin{tabular}{|c|c|c|c|c|c|c|c|c|c|c|c|c|c|c|}
\hline Sample Name & Sample Date & $\mathrm{pH}$ & $\begin{array}{c}\text { EC } \\
\mu \mathrm{S} / \mathrm{cm}\end{array}$ & $\begin{array}{c}\mathrm{SiO}_{2} \\
\mathrm{mg} / \mathrm{L}\end{array}$ & $\begin{array}{l}\mathrm{HCO}_{3} \\
\mathrm{mg} / \mathrm{L}\end{array}$ & $\begin{array}{c}\mathrm{CO}_{3} \\
\mathrm{mg} / \mathrm{L}\end{array}$ & $\begin{array}{c}\mathrm{Cl} \\
\mathrm{mg} / \mathrm{L}\end{array}$ & $\begin{array}{c}\mathrm{SO}_{4} \\
\mathrm{mg} / \mathrm{L}\end{array}$ & $\begin{array}{c}\mathrm{NO}_{3}-\mathrm{N} \\
\mathrm{mg} / \mathrm{L}\end{array}$ & $\begin{array}{c}\mathrm{Na} \\
\mathrm{mg} / \mathrm{L}\end{array}$ & $\begin{array}{c}\mathrm{K} \\
\mathrm{mg} / \mathrm{L}\end{array}$ & $\begin{array}{c}\mathrm{Ca} \\
\mathrm{mg} / \mathrm{L}\end{array}$ & $\begin{array}{c}\mathrm{Mg} \\
\mathrm{mg} / \mathrm{L}\end{array}$ & $\begin{array}{c}\mathrm{Br} \\
\mathrm{mg} / \mathrm{L}\end{array}$ \\
\hline Ammonia Tanks & 25-Apr-11 & 7.17 & 72 & 0.4 & 25.7 & $<0.1$ & 1.90 & 4.8 & $<0.01$ & 2.08 & 0.48 & 7.84 & 0.81 & $<0.01$ \\
\hline Ammonia Tanks & 29-Jun-11 & 7.66 & 93 & 0.6 & 38.2 & $<0.1$ & 2.60 & 7.2 & $<0.01$ & 2.82 & 1.01 & 13.4 & 1.05 & 0.018 \\
\hline Ammonia Tanks & 19-Oct-11 & 6.66 & 60 & 0.7 & 24 & $<0.1$ & 3.04 & 3.32 & 0.02 & 2.03 & 0.82 & 7.97 & 0.88 & $<0.01$ \\
\hline Ammonia Tanks & 17-Jan-12 & 7.21 & 136 & 1.6 & 37.2 & $<0.1$ & 14.30 & 7.2 & 0.01 & 9.21 & 1.77 & 15.3 & 1.22 & 0.01 \\
\hline Ammonia Tanks & 27-Mar-12 & 7.44 & 44 & 0.4 & 17.2 & $<0.1$ & 2.50 & 2.1 & $<0.01$ & 2.54 & 0.71 & 4.67 & 0.55 & 0.01 \\
\hline Buckboard Mesa & 25-Apr-11 & 7.13 & 42 & 0.3 & 12.0 & $<0.1$ & 1.60 & 4.1 & 0.39 & 1.78 & 0.26 & 4.25 & 0.58 & $<0.01$ \\
\hline Buckboard Mesa & 29-Jun-11 & 7.49 & 69 & 0.6 & 25.7 & $<0.1$ & 2.40 & 5.6 & 0.01 & 2.17 & 1.32 & 8.80 & 0.74 & 0.010 \\
\hline Buckboard Mesa & 19-Oct-11 & 6.7 & 52 & 0.8 & 22.6 & $<0.1$ & 1.26 & 2.73 & 0.01 & 0.96 & 1.06 & 6.73 & 0.91 & 0.01 \\
\hline Buckboard Mesa & 17-Jan-12 & \multicolumn{13}{|c|}{ NO SAMPLE } \\
\hline Buckboard Mesa & 27-Mar-12 & 7.29 & 31 & 0.3 & 11.3 & $<0.1$ & 2.50 & 2.1 & $<0.01$ & 2.54 & 0.71 & 4.67 & 0.55 & 0.01 \\
\hline Sagebrush & 25-Apr-11 & 7.29 & 86 & 0.7 & 35.2 & $<0.1$ & 0.60 & 2.6 & $<0.01$ & 2.08 & 0.64 & 12.2 & 0.99 & 0.012 \\
\hline Sagebrush & 29-Jun-11 & 7.83 & 121 & 0.9 & 54.2 & $<0.1$ & 2.80 & 9.7 & 0.02 & 2.44 & 2.58 & 17.9 & 1.32 & $<0.01$ \\
\hline Sagebrush & 19-Oct-11 & 6.86 & 94 & 0.9 & 51.8 & $<0.1$ & 1.07 & 1.24 & 0.01 & 0.84 & 1.61 & 11.1 & 1.37 & 0.01 \\
\hline Sagebrush & 17-Jan-12 & 7.49 & 104 & 1.4 & 55.4 & $<0.1$ & 1.50 & 0.4 & 0.01 & 1.24 & 2.75 & 9.45 & 1.27 & $<0.01$ \\
\hline Sagebrush & 27-Mar-12 & 7.43 & 34 & 0.3 & 16.6 & $<0.1$ & 1.00 & 0.9 & $<0.01$ & 1.14 & 0.54 & 4.13 & 0.62 & $<0.01$ \\
\hline Dead Horse Flat & 25-Apr-11 & 7.19 & 36 & 0.3 & 13.8 & $<0.1$ & 0.70 & 2.5 & 0.16 & 0.96 & 0.16 & 4.89 & 0.53 & $<0.01$ \\
\hline Dead Horse Flat & 28-Jun-11 & 7.73 & 121 & 0.9 & 62.9 & $<0.1$ & 2.20 & 6.0 & 0.02 & 2.06 & 1.11 & 19.8 & 1.90 & $<0.01$ \\
\hline Dead Horse Flat & 19-Oct-11 & 7.25 & 80 & 0.7 & 43.5 & $<0.1$ & 0.65 & 2.47 & 0.02 & 0.47 & 0.61 & 12.1 & 1.55 & 0.01 \\
\hline Dead Horse Flat & 17-Jan-12 & 7.12 & 41 & 0.5 & 20.8 & $<0.1$ & 0.90 & 0.9 & $<.01$ & 0.98 & 0.71 & 5.3 & 0.81 & $<.01$ \\
\hline Dead Horse Flat & 27-Mar-12 & 7.37 & 28 & 0.2 & 13 & $<0.1$ & 0.80 & 1.3 & $<.01$ & 1.01 & 0.37 & 3.36 & 0.46 & $<.01$ \\
\hline Silent Canyon & 25-Apr-11 & 7.05 & 28 & 0.1 & 10.7 & $<0.1$ & 0.70 & 2.1 & 0.13 & 0.96 & 0.20 & 3.40 & 0.34 & $<0.01$ \\
\hline Silent Canyon & 29-Jun-11 & 7.71 & 94 & 0.4 & 45.8 & $<0.1$ & 2.00 & 5.1 & $<0.01$ & 2.00 & 0.74 & 15.9 & 0.86 & $<0.01$ \\
\hline Silent Canyon & 19-Oct-11 & 6.73 & 66 & 0.6 & 35 & $<0.1$ & 0.97 & 2.55 & 0.01 & 0.72 & 0.69 & 11 & 0.93 & 0.01 \\
\hline Silent Canyon & 17-Jan-12 & 7.33 & 51 & 0.6 & 18.8 & $<0.1$ & 0.90 & 1 & 0.01 & 1.25 & 1.21 & 6.65 & 0.68 & $<.01$ \\
\hline Silent Canyon & 27-Mar-12 & 7.26 & 28 & 0.1 & 17.9 & $<0.1$ & 0.90 & 1.2 & $<0.01$ & 1.01 & 0.56 & 3.09 & 0.37 & $<0.01$ \\
\hline Pinyon Juniper & 25-Apr-11 & 7.31 & 42 & 0.3 & 17.1 & $<.1$ & 0.80 & 3.27 & 0.14 & 1.04 & 0.24 & 5.77 & 0.63 & $<.01$ \\
\hline Pinyon-Juniper & 29-Jun-11 & 7.75 & 88 & 0.5 & 44.0 & $<.1$ & 1.70 & 4.1 & 0.01 & 1.58 & 0.76 & 14.2 & 1.14 & $<.01$ \\
\hline Pinyon-Juniper & 19-Oct-11 & 6.88 & 125 & 0.8 & 71.6 & $<0.1$ & 1.19 & 1.34 & 0.01 & 3.11 & 2.53 & 12 & 0.98 & $<.01$ \\
\hline Pinyon-Juniper & 17-Jan-12 & \multicolumn{13}{|c|}{ NO SAMPLE } \\
\hline Pinyon-Juniper & 27-Mar-12 & 7.46 & 38 & 0.1 & 17.9 & $<0.1$ & 0.80 & 1.2 & $<0.01$ & 1.01 & 0.49 & 4.08 & 0.61 & $<0.01$ \\
\hline
\end{tabular}




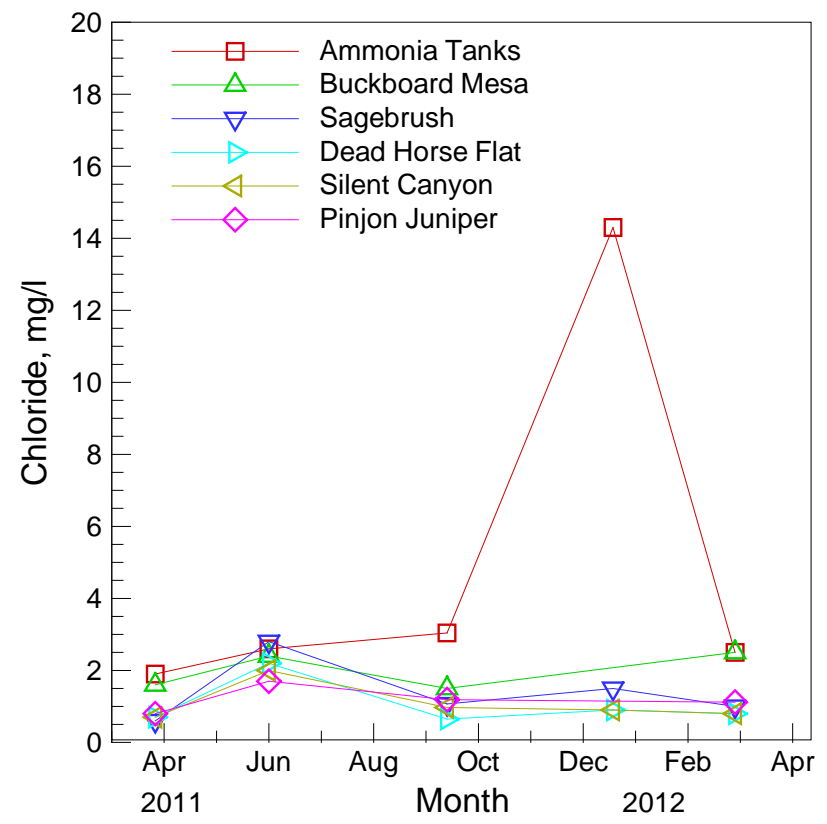

Figure 12. Time series of chloride in precipitation at each of the six sites.

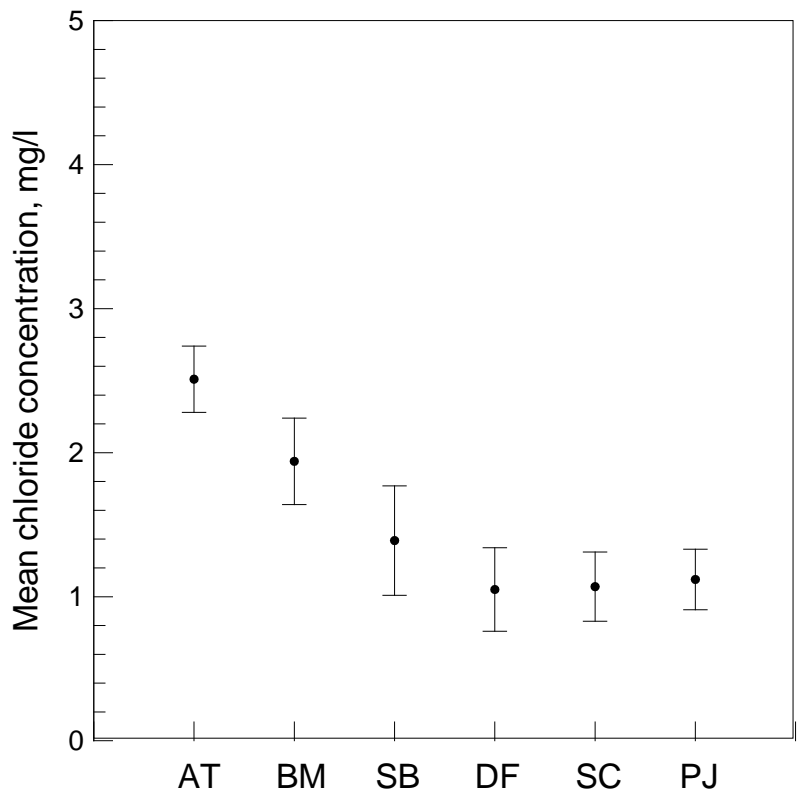

Figure 13. Mean chloride in bulk precipitation gauges at the six sites, between April 27, 2011 and March 27, 2012. Error bars are represented as standard error. 
Precise determination of the amount of chloride associated with dry deposition is a nontrivial matter. It is often reported as mass per volume of water, which is incorrect because dry deposition is a mass deposited over an area of land over an interval of time (mass flux), as opposed to being a mass dissolved in a volume of water (concentration). The concept is easily viewed if one realizes that in the absence of wind, dry deposition is chloride from the atmosphere that is deposited on the land surface. It is usually reported as a concentration because chloride derived from dry deposition is often measured in bulk collectors that additionally collect rain water. However, the value is not a true concentration, and instead its 'concentration' is completely dependent upon the amount of rainfall received in the collector during the particular interval of time. Since bulk collectors collect precipitation as well, chloride in samples from bulk collectors record both wet and dry deposition.

The amount of chloride collected in bulk gauge, however, does not truly represent the amount of wet or dry deposition. The reason is that unlike chloride that is deposited on the ground, chloride deposited in a collector does not have an opportunity to become resuspended with blowing wind. Dust blows back and forth across Pahute Mesa without there being any net gain or loss of chloride on the soil; however, if this dust is deposited in the bulk gauges, it cannot become resuspended so it would be counted as dry deposition. Chloride collected in bulk gauges, therefore, represents a maximum amount of dry deposition that could occur.

The point of the above discussion is that quantifying the bulk deposition of chloride (derived from both wet and dry deposition) can be difficult if the amount of resuspension is unknown. Bulk samplers record a maximum load of chloride from the atmosphere. It is stated above that it is incorrect to state dry-deposition as a concentration because it is a value that is dependent upon precipitation amount, which varies from year to year. However, it can be viewed as a concentration, by subtracting chloride concentration in precipitation (for the case of this study, $0.16 \pm 0.014 \mathrm{mg} / \mathrm{L})$ from the mean concentration in the bulk gauges $(1.3 \pm 0.14 \mathrm{mg} / \mathrm{L}$, excluding samples from Ammonia Tanks) to get a value that is $1.14 \mathrm{mg} / \mathrm{L}$. In any event, the bulk precipitation value is what is needed in the calculations; this value is $1.3 \mathrm{mg} / \mathrm{L}$ and represents a maximum possible chloride input to groundwater from both wet and dry deposition.

\section{Chloride Deposition based upon ${ }^{36} \mathrm{Cl}$ Production}

Chloride in precipitation can also be estimated knowing the ${ }^{36} \mathrm{Cl} / \mathrm{Cl}$ ratio in precipitation and rate of meteoric ${ }^{36} \mathrm{Cl}$ deposition. The rate of atmospheric deposition of ${ }^{36} \mathrm{Cl}$ has been difficult to quantify (Phillips, 2000), but the most recent average estimate is $30.5 \pm 7{ }^{36} \mathrm{Cl}$ atoms $/ \mathrm{m}^{2}-\mathrm{s}^{1}$ over the continental US (Moysey et al., 2003). Similar to the dependence on latitude of ${ }^{36} \mathrm{Cl}$ flux, the ${ }^{36} \mathrm{Cl} / \mathrm{Cl}$ ratio is not uniform throughout the US; the most recent accepted value of ${ }^{36} \mathrm{Cl} / \mathrm{Cl}$ is $520 \times 10^{-15}$ (Moysey et al., 2003). The concentration of chloride deposition is calculated as $108.9 \mathrm{mg} / \mathrm{m}^{2}$-yr; using a value of $200 \mathrm{~mm} / \mathrm{yr}$ precipitation (Sagebrush site) results in a bulk deposition rate of chloride of $0.544 \mathrm{mg} / \mathrm{L}$. At Dead Horse Flat, the deposition rate is $0.39 \mathrm{mg} / \mathrm{L}$ (281 mm/yr precipitation). These can be compared with the measurement of Meijer (2002) $0.35 \mathrm{mg} / \mathrm{L}$ in the Kawich Range (chloride values ranged between 0.1 and $0.7 \mathrm{mg} / \mathrm{L}$ ). The mean of these two values is an annual deposition rate of $0.47 \mathrm{mg} / \mathrm{L}$. To calculate uncertainty, it was assumed chloride in precipitation is distributed uniformly over the range of Meijer's data. The standard deviation is then calculated as $s=R / \sqrt{12}=0.17 \mathrm{mg} / \mathrm{L}$ (Haan, 1977), where $R$ is Meijer's range of values. 


\section{Chloride in Precipitation Summary}

Chloride concentration in precipitation $\left(C_{p}\right)$ appears to range between $0.16 \mathrm{mg} / \mathrm{L}$ (wet deposition only) and $1.3 \mathrm{mg} / \mathrm{L}$ (clearly an overestimate of wet and dry deposition) based upon data collected for this project. Based upon atmospheric ${ }^{36} \mathrm{Cl}$ production and the measured ratio ${ }^{36} \mathrm{Cl} / \mathrm{Cl}$, an average bulk chloride deposition rate for Pahute Mesa is $0.47 \mathrm{mg} / \mathrm{L}$ per year. There is too much uncertainty in the individual values to discriminate between the Sagebrush and Dead Horse Flat sites such that the value $0.47 \mathrm{mg} / \mathrm{L}$, with a standard deviation of $0.17 \mathrm{mg} / \mathrm{L}$, is used in the calculations. In addition to this value agreeing well with Meijer's mean $C_{p}$ value, it also is close to the value used in the calculations of Dettinger (1989; $C_{p}=0.4 \mathrm{mg} / \mathrm{L}$ ) and Russell and Minor (2002; $C_{p}$ is a range between 0.26 and $0.86 \mathrm{mg} / \mathrm{L}$ in Monte Carlo simulations). Russell and Minor's range was determined using Monte Carlo analysis of ${ }^{36} \mathrm{Cl}$ deposition, which produced a range of $C_{p}$ values as opposed to the method used in this report which produced a constant $C_{p}$.

\section{Chloride in Pahute Mesa Groundwater}

\section{Pahute Mesa Groundwater}

The mean chloride concentration in Pahute Mesa groundwater is based upon groundwater collected from wells on Pahute Mesa (there are no springs) with data obtained from the UGTA Geochemistry Database (restricted access) and from water samples collected from four emplacements boreholes on Pahute Mesa. Wells that were originally evaluated for water chemistry and isotopic signatures by Thomas et al. (2002) and Rose et al. (2006) were considered, plus, new wells drilled since these reports were published (Figure 14). Only water samples that were deemed representative of groundwater were used; that is, samples collected during drilling, well logging, and well development were excluded in the analysis. In addition, most samples collected by bailer were excluded because wells are generally not adequately purged of stagnant water when bailers are used.

Table 6 lists the mean chloride concentration for each well considered for this study. Three wells in Table 6 have elevated levels of tritium $\left({ }^{3} \mathrm{H}\right)$ indicating that these wells were impacted by underground testing (ER-20-5 \#3, U-20n PS 1DD-H, ER-20-7). However, testing does not seem to change chloride and sulfate concentrations (Kwicklis et al., 2005) so these wells were included in analysis of Pahute Mesa chloride concentrations. There is a wide range in mean chloride concentration from 2.6 to $97.7 \mathrm{mg} / \mathrm{L}$ (Appendix A); their spatial distribution is displayed on Figure 15. Lower chloride concentrations are observed in eastern and central Pahute Mesa while higher concentrations are found in western Pahute Mesa and southwestward along Thirsty Canyon. The general direction of groundwater flow is from northeast to southwest (Fenelon et al., 2010; Stoller-Navarro, 2006) in the same direction that chloride concentration increases. Sulfate concentration also increases downgradient (Figure 16). Hydrothermal alteration has been observed in boreholes in western Pahute Mesa, Thirsty Canyon, Oasis Valley, Yucca Mountain, and south of Pahute Mesa (e.g. Stoller-Navarro, 2006; Benedict et al., 2000; IT, 1998; Blankennagel and Weir, 1973; Schoff and Moore, 1964) and is likely the source of elevated chloride and sulfate concentrations in western Pahute Mesa.

Six wells that possibly represent perched groundwater or the regional water table are designated with a WT in Table 6 and shown as white circles with dots on Figure 14. Four of these are emplacement boreholes with short saturated zones (4.0-63.4 m). It is unknown if the 
water in these emplacement boreholes is perched groundwater, the regional water table, or residual drilling fluid (Hershey and Brikowski, 1995; Brikowski et al., 1993; Gardner and Brikowski, 1993). For example, drilling fluid for these boreholes likely originated either from UE-19c Water Well or U-20 Water Well, both of which have isotopic signatures typical of

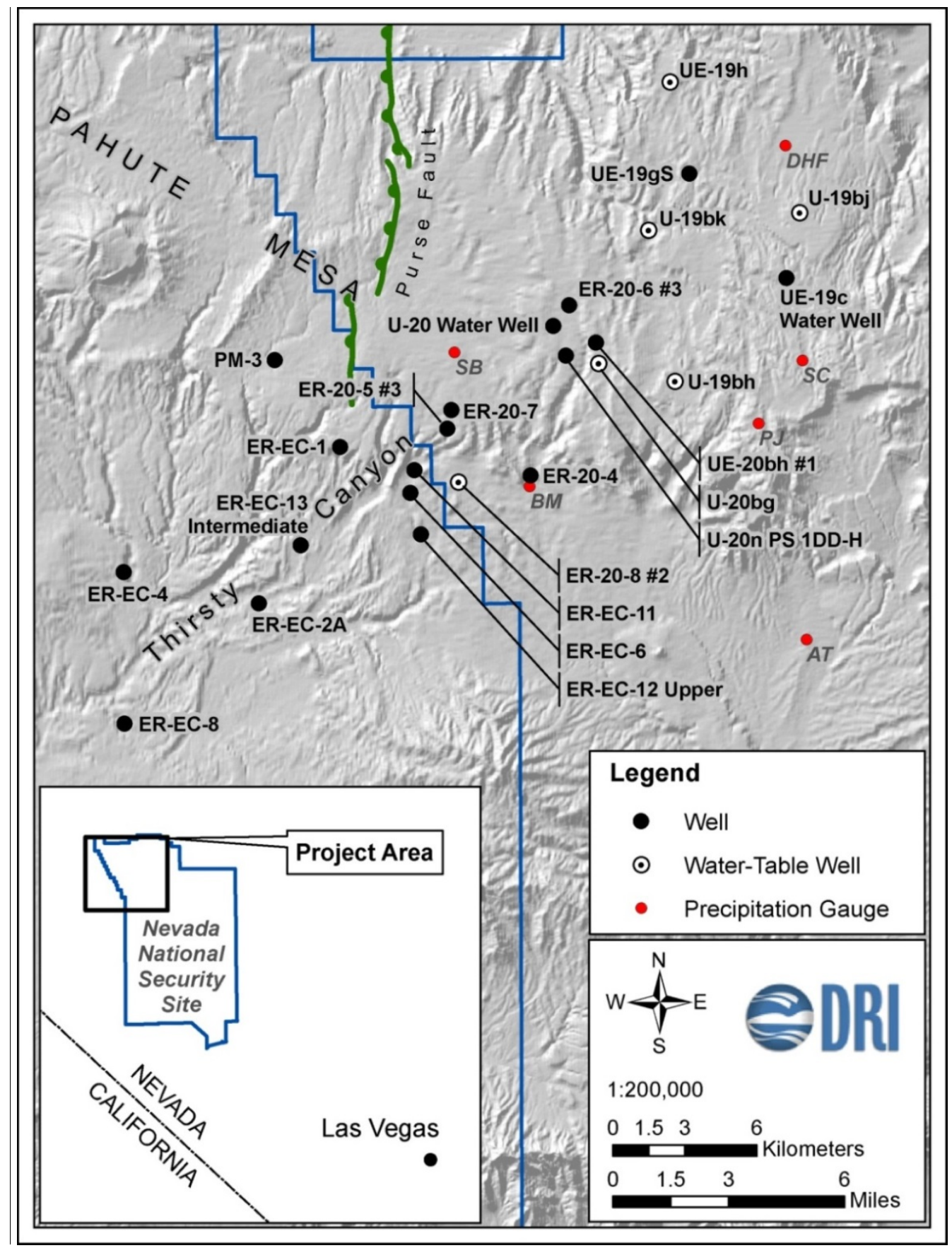

Figure 14. Location of wells on Pahute Mesa with water samples that are representative of groundwater and that were evaluated for use in the chloride mass-balance model. Well names designated as white circles with dots sample the water table or perched groundwater. Precipitation gauges are Ammonia Tanks (AT), Buckboard Mesa (BM), Sagebrush (SB), Dead Horse Flat (DHF), Silent Canyon (SC), and Pinyon-Juniper (PJ). 
Table 6. Chloride concentrations and isotopic signatures in groundwater from wells and emplacement boreholes in Pahute Mesa. ND = no data.

\begin{tabular}{lccccc}
\hline \multicolumn{1}{c}{ Well } & $\begin{array}{c}\mathrm{Cl} \\
(\mathrm{mg} / \mathrm{L})\end{array}$ & $\begin{array}{c}\mathrm{SO}_{4} \\
(\mathrm{mg} / \mathrm{L})\end{array}$ & $\begin{array}{c}\delta^{2} \mathrm{H} \\
(\%)\end{array}$ & $\begin{array}{c}\delta^{18} \mathrm{O} \\
(\%)\end{array}$ & $\begin{array}{c}\text { Water-Table } \\
\text { Wells }\end{array}$ \\
\hline ER-20-4 & 4.7 & 16.9 & -115 & -15.1 & \\
ER-20-5 \#3 & 17.1 & 34.0 & -114 & -15.2 & \\
ER-20-6 \#3 & 12.2 & 30.5 & -114 & -15.0 & \\
ER-20-7 & 30.1 & 51.3 & -113 & -15.4 & \\
ER-20-8 \#2 & 27.5 & 50.4 & -116 & -15.3 & WT \\
ER-EC-1 & 94.6 & 124.1 & -116 & -14.9 & \\
ER-EC-2A & 59.2 & 90.9 & -116 & -14.9 & \\
ER-EC-4 & 85.0 & 118.0 & -114 & -14.6 & \\
ER-EC-6 & 49.9 & 73.3 & -116 & -15.1 & \\
ER-EC-8 & 52.3 & 86.8 & -115 & -14.8 & \\
ER-EC-11 & 43.5 & 70.0 & -116 & -15.3 & \\
ER-EC-12 Upper & 15.5 & 35 & $\mathrm{ND}$ & $\mathrm{ND}$ & \\
ER-EC-13 Intermediate & 58.7 & 89.7 & $\mathrm{ND}$ & $\mathrm{ND}$ & \\
PM-3 & 97.7 & 127.3 & -116 & -15.0 & \\
U-19bh & 8.6 & 22.8 & -102 & -13.5 & WT \\
U-19bj & 15.7 & 27.5 & -101 & -13.5 & WT \\
U-19bk & 4.8 & 8.4 & -115 & -15.0 & WT \\
UE-19c Water Well & 2.6 & 6.20 & -111 & -15.2 & \\
UE-19gS & 12.9 & 50.75 & -114 & -14.5 & \\
UE-19h & 9.1 & 38.2 & -111 & -14.6 & WT \\
U-20 Water Well & 11.6 & 29.0 & -113 & -14.7 & \\
U-20bg & 6.6 & 14.8 & -107 & -13.7 & WT \\
U-20n PS 1DD-H & 11.5 & 29.7 & -113 & -14.7 & \\
UE-20bh \#1 & 4.0 & 7.8 & -113 & -15.0 & \\
\hline
\end{tabular}




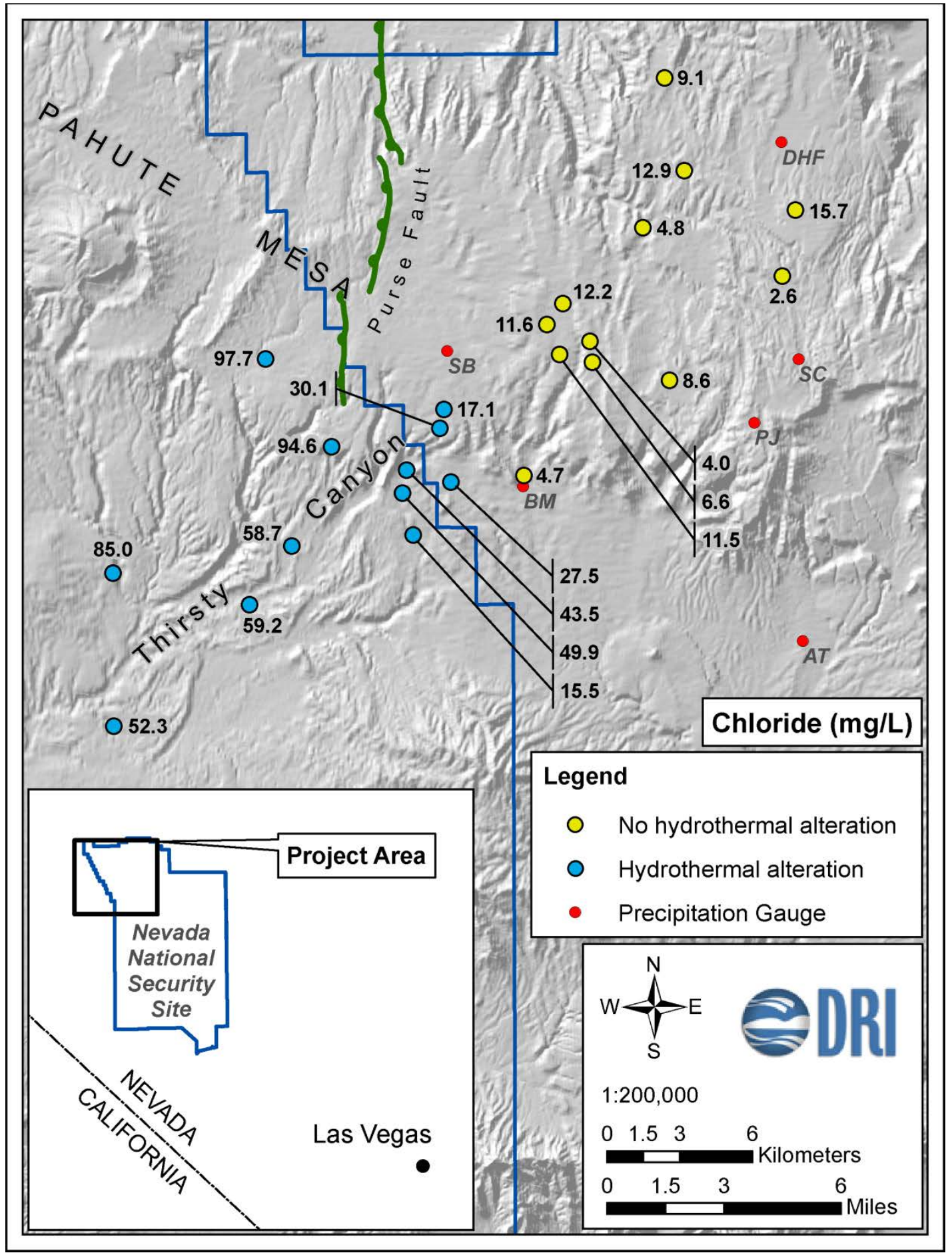

Figure 15. Average chloride concentrations in groundwater from wells on Pahute Mesa, in mg/L. 


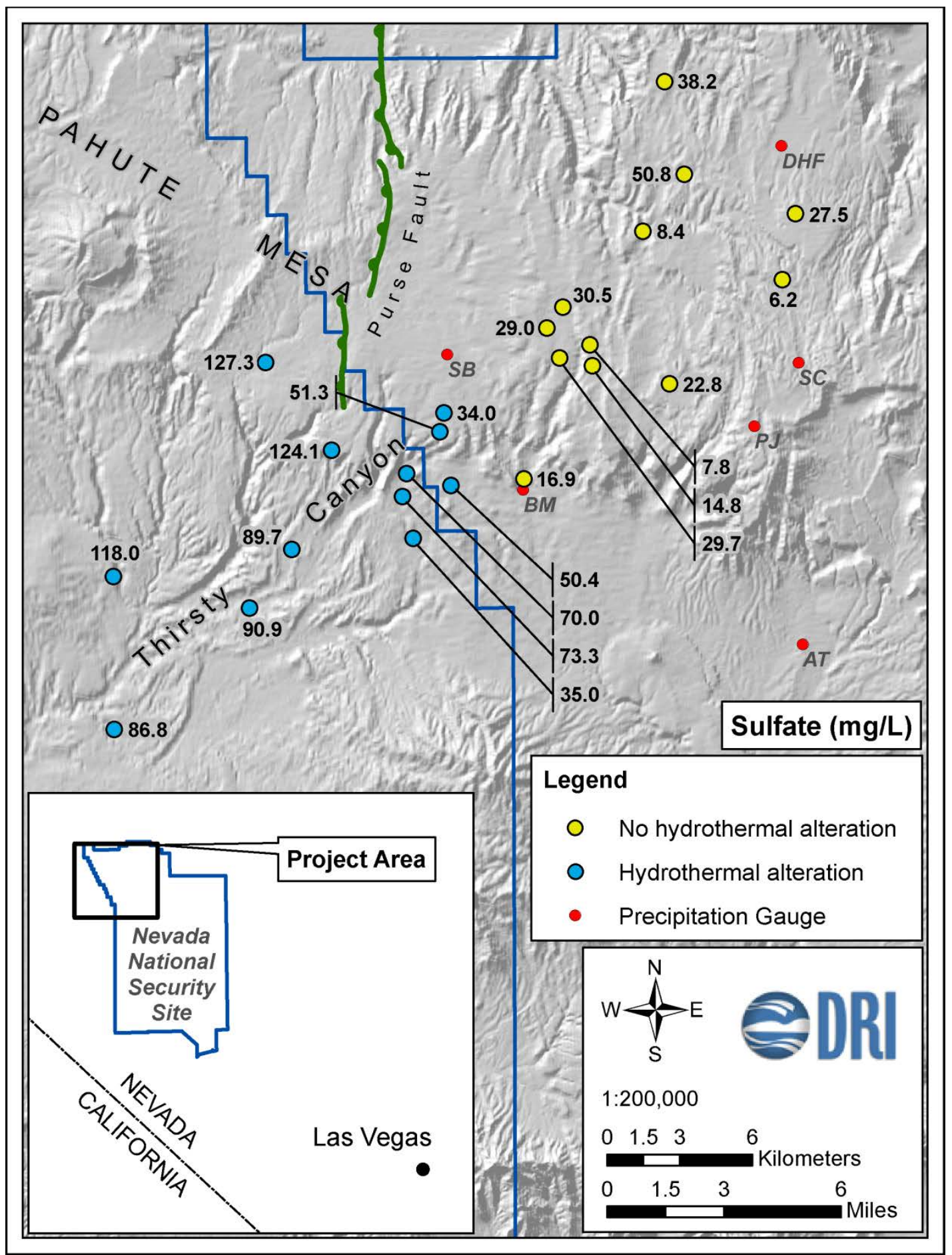

Figure 16. Average sulfate concentrations in groundwater from wells on Pahute Mesa, in mg/L. 
Pahute Mesa groundwater (Table 6) making drilling fluid indistinguishable from groundwater. The other two wells, UE-19h and ER-20-8 \#2, penetrate the water table. Chloride concentrations for these wells and emplacement boreholes (Appendix C) vary from 4.8 to $27.5 \mathrm{mg} / \mathrm{L}$. In the emplacement boreholes, chloride concentrations increase with increasing isotopic signature (Figure 17) suggesting the water in several of these large diameter boreholes may be evaporated or affected by surface runoff draining into the holes. Only the isotopic signature of emplacement borehole UE-19bk is consistent with the isotopic signature of groundwater east of the Purse Fault (Figure 18). Well ER-20-8 \#2 is southeast of the Purse Fault and has elevated chloride concentrations suggestive of influence from hydrothermal alteration. Well UE-19h penetrates about $172 \mathrm{~m}$ of the water table with a chloride concentration of $9.1 \mathrm{mg} / \mathrm{L}$. Based upon these few wells, there does not appear to be any direct correlation between wells that penetrate groundwater near the water table and chloride concentration.

As noted previously, the CMB method requires that there be no increase in chloride concentration in groundwater as a result of water-rock reactions. Chloride concentrations in groundwater west of the Purse Fault increase probably because of water-rock reactions with hydrothermally altered rock (and ER-20-8 \#2); therefore chloride concentrations west of the Purse Fault were excluded from recharge estimates. Three of the emplacement boreholes were also excluded because their isotopic signatures suggest that their chloride concentrations are not representative of perched groundwater or Pahute Mesa groundwater. The mean chloride concentration of groundwater in eastern and central Pahute Mesa used to estimate groundwater recharge is $8.2 \pm 1.4 \mathrm{mg} / \mathrm{L}$ (uncertainty reported as standard error about the mean); the mean $\delta^{2} \mathrm{H}$ for these wells is $-113 \%$ and the mean $\delta^{18} \mathrm{O}$ is $-14.9 \%$ (Table 7).

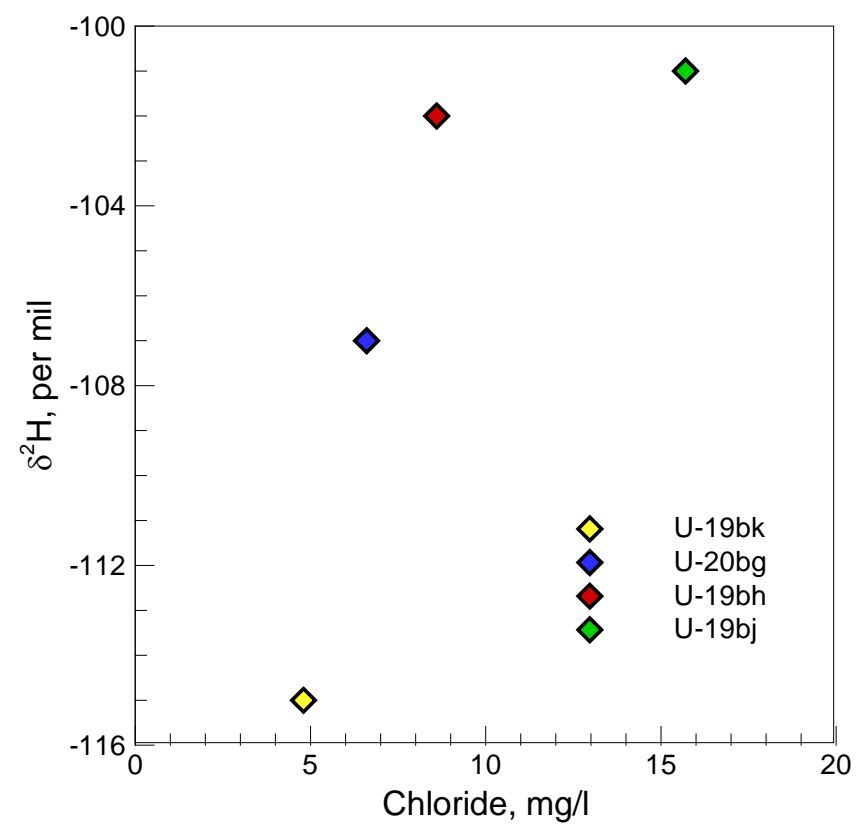

Figure 17. Variation in chloride concentration with isotopic signature for four emplacement boreholes with standing water. Chloride concentrations increase with increasing isotopic signature. 


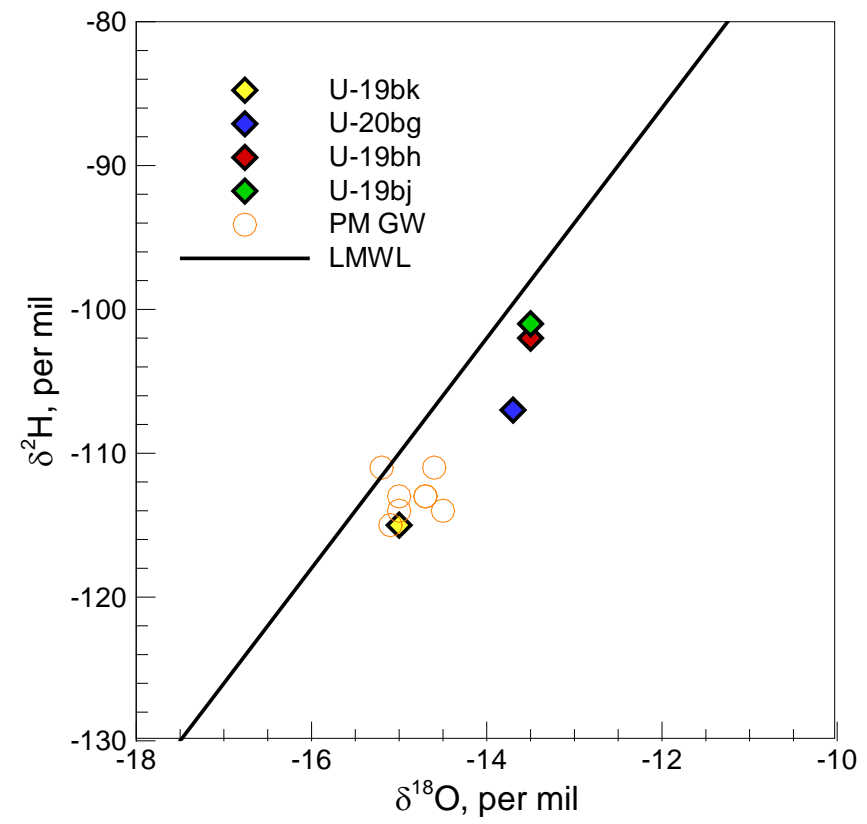

Figure 18. Isotopic signature of four emplacement boreholes with standing water in relation to the local meteoric water line (LMWL; $\delta^{2} \mathrm{H}=7.1 \delta^{18} \mathrm{O}-2.7$; Thomas et al., 2002). U-19bk is similar to Pahute Mesa groundwater (PM GW). The other emplacement boreholes have heavier isotopic signatures suggesting that these waters are not representative of perched groundwater or Pahute Mesa groundwater.

Table 7. Average chloride, sulfate, $\delta^{2} \mathrm{H}$, and $\delta^{18} \mathrm{O}$ with standard deviation for wells used to represent groundwater east of the Purse Fault in Pahute Mesa.

\begin{tabular}{lcccc}
\hline \multicolumn{1}{c}{ Well } & $\begin{array}{c}\mathrm{Cl} \\
(\mathrm{mg} / \mathrm{L})\end{array}$ & $\begin{array}{c}\mathrm{SO}_{4} \\
(\mathrm{mg} / \mathrm{L})\end{array}$ & $\begin{array}{c}\delta^{2} \mathrm{H} \\
(\%)\end{array}$ & $\begin{array}{c}\delta^{18} \mathrm{O} \\
(\%)\end{array}$ \\
\hline ER-20-4 & 4.7 & 16.9 & -115 & -15.1 \\
ER-20-6 \#3 & 12.2 & 30.5 & -114 & -15.0 \\
U-19bk & 4.8 & 8.4 & -115 & -15.0 \\
UE-19c Water Well & 2.6 & 6.20 & -111 & -15.2 \\
UE-19gS & 12.9 & 50.75 & -114 & -14.5 \\
UE-19h & 9.1 & 38.2 & -111 & -14.6 \\
U-20 Water Well & 11.6 & 29.0 & -113 & -14.7 \\
U-20n PS 1DD-H & 11.5 & 29.7 & -113 & -14.7 \\
UE-20bh \#1 & 4.0 & 7.8 & -113 & -15.0 \\
& & & & \\
Mean & 8.2 & 24.2 & -113 & -14.9 \\
SD & 4.1 & 15.4 & 1.4 & 0.2 \\
Standard error & 1.4 & 5.13 & 0.5 & 0.07 \\
\hline
\end{tabular}




\section{$\underline{\text { Rainier Mesa Unsaturated Zone Water }}$}

An evaluation of unsaturated zone water in Rainier Mesa was previously conducted to determine the average chloride concentration for an infiltration study of Rainier Mesa (Appendix D). Rainier Mesa, east of Pahute Mesa, has similar geology to Pahute Mesa, but is higher in elevation. Pahute Mesa elevations range from 1,676 m to over 2,134 m (Stoller-Navarro, 2006); Rainier Mesa elevations range from 2,225 m to 2,341 m (Stoller-Navarro, 2008). Rainier Mesa consists of a sequence of relatively young Tertiary-age volcanic tuffs draped over an irregular substrate of much older Paleozoic sedimentary and Mesozoic intrusive rocks (Stoller-Navarro, 2008). Based on the evaluation of chloride concentration in water found in the Rainier Mesa tunnels, seeps, and lysimeters chloride concentrations were considered to be most representative of recharge water in the Rainier Mesa unsaturated zone. The average chloride concentration for these samples was $8.1 \mathrm{mg} / \mathrm{L}$ with a standard deviation of $3.7 \mathrm{mg} / \mathrm{L}$.

Hershey et al. (2008) reviewed the isotopic data for the Rainer Mesa. Data were limited to water samples from weirs and sumps in U12n Tunnel (Russell, 1987), two precipitation stations on top of Rainier Mesa (Ingraham et al., 1990, 1991), and tunnel portal samples from U12e, U12n, and U12t tunnels (Hershey et al., 2008). Because weir and sump samples from U12n Tunnel were modified by isotopic exchange in the high humidity environment in the tunnels, these samples were excluded by Hershey et al. (2008) from consideration. The remaining tunnel portal samples were not evaporated and fell between the winter precipitationweighted, isotopic means for the two Rainier Mesa precipitation stations (Figure 19). Previous authors have shown that groundwater recharge in southern Nevada is made up almost exclusively of winter precipitation (e.g., Simpson et al., 1972; Winograd and Riggs, 1984; Ingraham et al., 1990, Ingraham et al., 1991; Winograd et al. 1998). Because the portal gas-seal plug and door samples were not evaporated and were similar isotopically to winter precipitation, these samples were used by Hershey et al. (2008) to represent tunnel waters in the geochemical flowpath modeling (Table 8).

Table 8. Average stable isotope data for rainier mesa tunnel portal gas-seal doors and plugs samples (from Hershey et al., 2008).

\begin{tabular}{ccc}
\hline Tunnel & $\delta^{2} \mathrm{H}(\%)$ & $\delta^{18} \mathrm{O}(\%)$ \\
\hline U12e & -104 & -13.7 \\
U12n & -103 & -13.8 \\
U12t & -106 & -14.0 \\
\hline
\end{tabular}




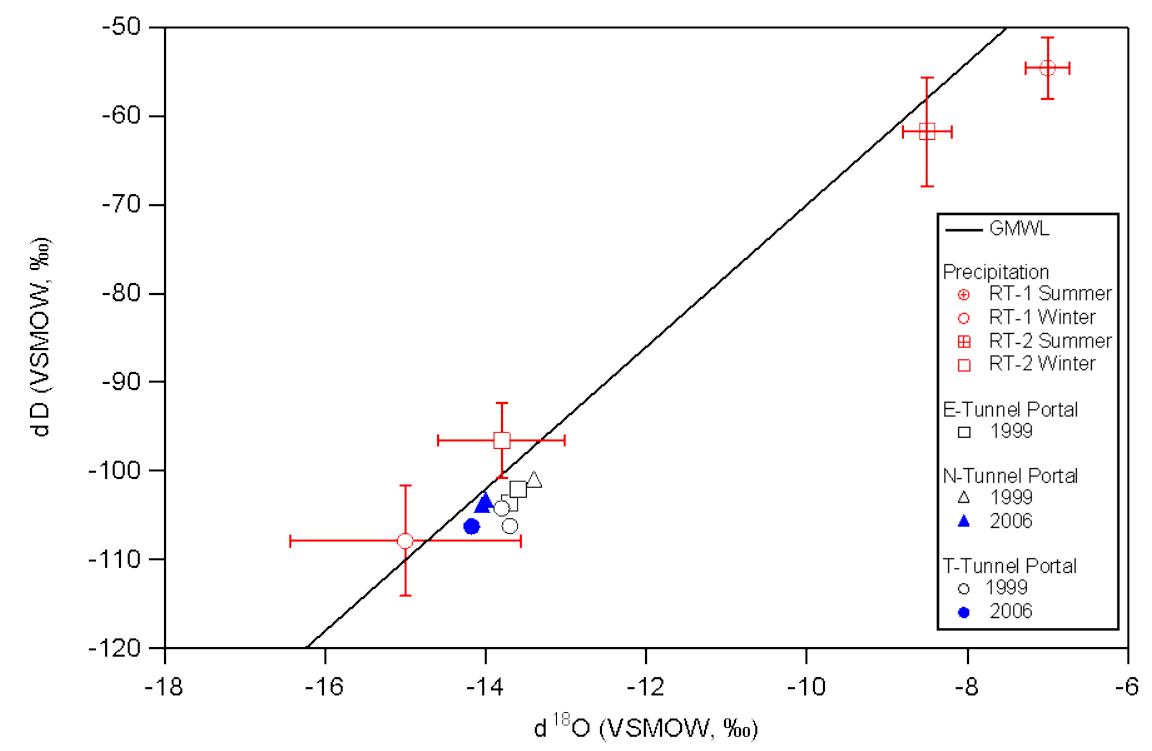

Figure 19. Stable isotopic data for Rainier Mesa precipitation and tunnel portal gas-seal plug and door samples. Also shown is the global meteoric water line (Craig, 1961; figure from Hershey et al., 2008).

\section{NNSS Springs}

Because there are no springs on Pahute Mesa, 10 springs on the NNSS were sampled for their chloride content and evaluated for use in the Pahute Mesa CMB model (Figure 20). Isotopic analyses were also conducted to assess any evaporation at the spring source; analytical results are in Appendix C. Most of the spring samples were collected in February and March so that spring discharge was representative of base-flow conditions before the beginning of spring-time snow melt (Lyles et al., 1990). Several of the springs had no obvious spring orifice and were significantly evaporated (Reitmann, Pavits, Gold Meadows); Cane Spring had multiple diffuse areas of spring discharge and was also significantly evaporated (Figure 21). Because of significant evaporation at the source of these springs, their chloride concentrations were not considered further. For the six remaining NNSS springs, the average chloride concentration was $7.5 \mathrm{mg} / \mathrm{L}$ with a standard deviation of $3.3 \mathrm{mg} / \mathrm{L}$ and a range from 2.5 (Cottonwood) to $11.7 \mathrm{mg} / \mathrm{L}$ (Tub). For these springs, the average $\delta^{18} \mathrm{O}=-12.6 \%$ and the average $\delta^{2} \mathrm{H}=-95 \%$; however, the range in isotopic signatures for the springs vary widely from isotopically light Captain Jack Spring $\left(\delta^{18} \mathrm{O}=-13.7 \%\right.$, $\delta^{2} \mathrm{H}=-103 \%$ ) to isotopically heavy Cottonwood Spring $\left(\delta^{18} \mathrm{O}=-11.7 \%\right.$ о, $\delta^{2} \mathrm{H}=-89 \%$ \%).

\section{Age of Pahute Mesa Groundwater}

Stoller-Navarro (2009, Appendix D) suggested that Pahute Mesa groundwater was recharged during the Pleistocene (ending approximately 12,000 years) and that groundwater recharge has not occurred under current climatic conditions. This assumption is based upon dissolved inorganic carbon (DIC) carbon $14\left({ }^{14} \mathrm{C}\right)$ absolute ages and the light stable isotopic signature of Pahute Mesa groundwater (also see Kwicklis et al., 2005). In the current study, chloride deposition and precipitation rates were assumed constant during the residence time of 
groundwater being sampled. This implies that recharge has occurred under current climatic conditions and not during the Pleistocene. There are several investigations that suggested that Pahute Mesa groundwater was recharged under current climatic conditions and may not Pleistocene age groundwater.

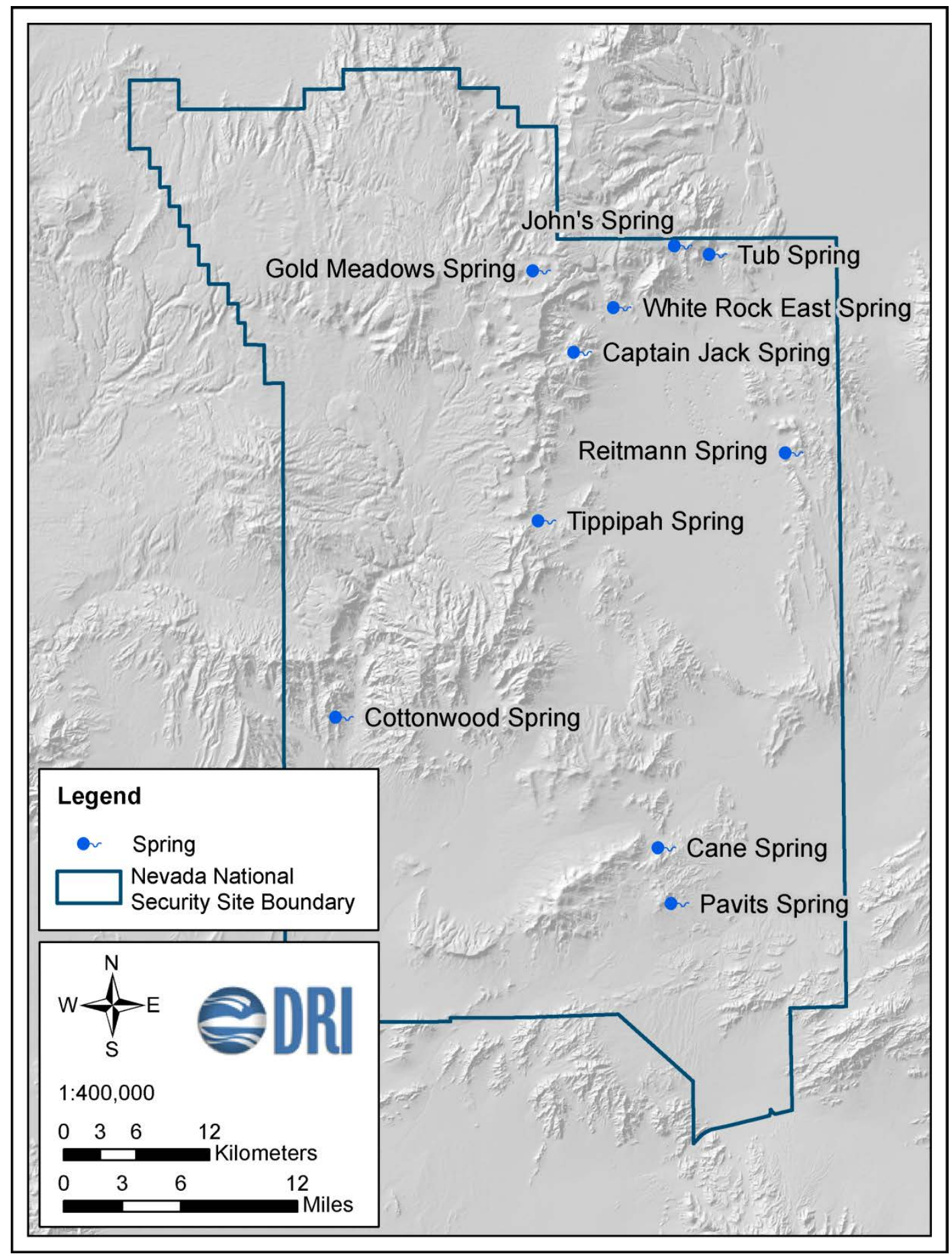

Figure 20. Location of springs at the NNSS sampled for this project. 


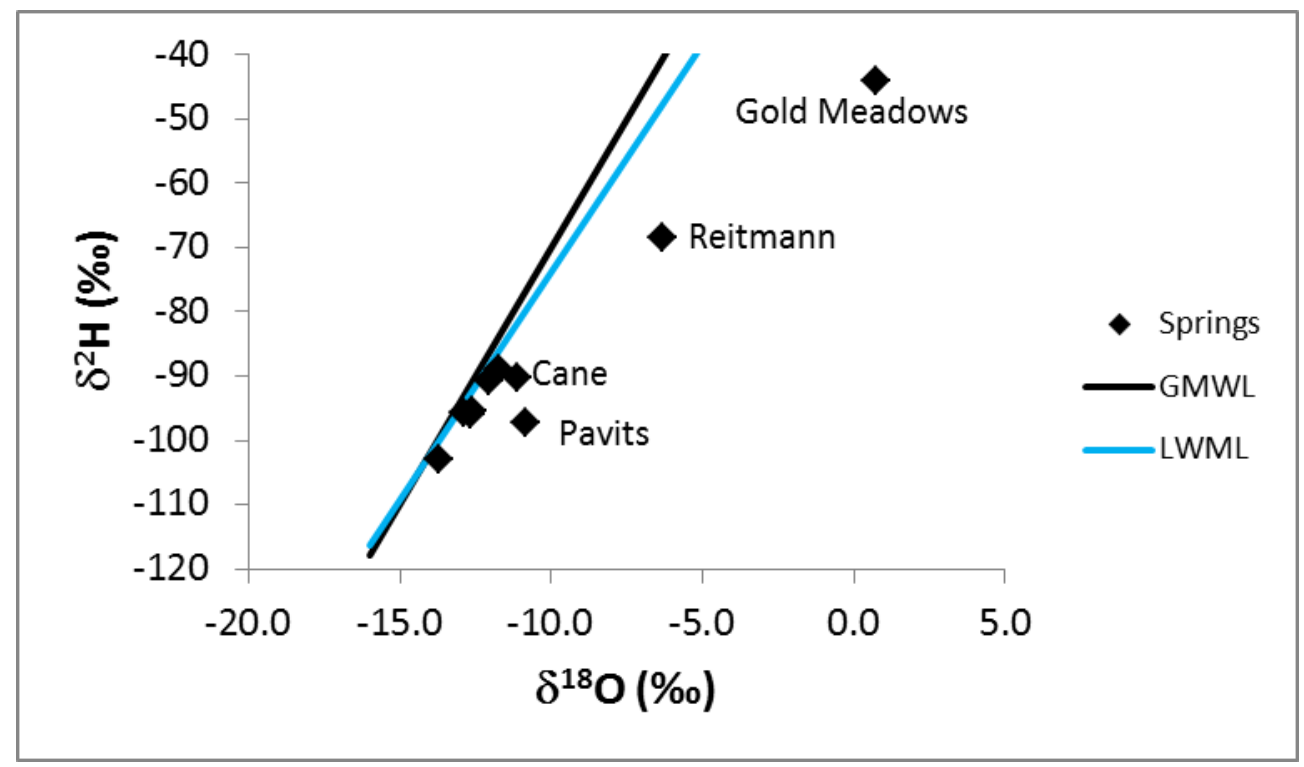

Figure 21. Isotopic signature of NNSS springs; the local meteoric water line (LMWL; $\delta^{2} \mathrm{H}=7.1 \delta^{18} \mathrm{O}-2.7$; Thomas et al., 2002) and the global meteoric water line (GMWL; $\delta^{2} \mathrm{H}=8 \delta^{18} \mathrm{O}+10$; Craig, 1961) are shown for reference.

Thomas et al. (2002) was perhaps the first to suggest that DIC ${ }^{14} \mathrm{C}$ data could be interpreted to show recharge occurred under current climatic conditions. They noted that recharge during the Pleistocene indicates relatively short flow paths and long travel times between recharge and discharge areas while recharge under current climatic conditions indicates long flow paths and short travel times. They also state that $\delta^{2} \mathrm{H}$ and $\delta^{18} \mathrm{O}$ data from other southern Nevada groundwater suggested that groundwater has been recharged since the last climate shift. Thomas et al. (2002) also observed that ${ }^{4} \mathrm{He}$ concentrations in Pahute Mesa groundwater with low ${ }^{3} \mathrm{He}$ concentrations indicated groundwater residence times of less than 10,000 years. They noted other supporting evidence such as decreasing DIC ${ }^{14} \mathrm{C}$ activity with corresponding increasing $\delta^{13} \mathrm{C}$ concentrations indicating water-rock reactions between groundwater and old carbonate minerals, which dilute groundwater DIC ${ }^{14} \mathrm{C}$ with DIC ${ }^{12} \mathrm{C}$, making groundwater look older than it actually is. Water-rock reaction modeling, accounting for DIC ${ }^{12} \mathrm{C}$ dilution, produced DIC ${ }^{14} \mathrm{C}$ travel times from Pahute Mesa to Oasis Valley from 1,900 to 6,200 years. Dissolved organic carbon (DOC) ${ }^{14} \mathrm{C}$ groundwater ages (time for groundwater to flow from its recharge area to the sampling point, or absolute ages), which are thought not to be affected by water-rock reactions with old carbonate minerals, were consistent with DIC ${ }^{14} \mathrm{C}$ travel times and ranged from 1,700 to 6,800 years.

Rose et al. (2006) updated the work by Thomas et al. (2002) by incorporating chemical and isotopic data from newly drilled wells between Pahute Mesa and Oasis Valley. They noted that new stable isotopic data were consistent with previous data in that Pahute Mesa groundwater had much lower $\delta^{2} \mathrm{H}$ and $\delta^{18} \mathrm{O}$ signatures than local precipitation. DIC ${ }^{14} \mathrm{C}$ groundwater travel times from Pahute Mesa to Oasis Valley, corrected for water-rock reactions with carbonate minerals, ranged from modern to 3,900 years, somewhat faster than those estimated by Thomas et al. (2002). DOC ${ }^{14} \mathrm{C}$ ages were mostly consistent with revised DIC ${ }^{14} \mathrm{C}$ travel times. 
Rose and Davisson (2002) and Davisson et al. (1999) presented several arguments using isotopic, chemical, and hydrogeologic data that groundwater beneath Pahute Mesa originates from higher elevation mountain ranges north of Pahute Mesa and from higher latitude basins that flows southward into Pahute Mesa. $\delta^{18} \mathrm{O}$ values of regional groundwater in central Nevada are similar to local mountain springs in the upper part of the regional flow systems. Small increases in $\delta^{18} \mathrm{O}$ along flowpaths indicated mixing with local recharge as groundwater flowed southward. Estimates of the isotopic signature of precipitation during the Pleistocene, assuming an average temperature decrease of $5^{\circ} \mathrm{C}$ at full glacial maximum, would produce $\delta^{18} \mathrm{O}$ values that were 2.6 to -2.8 \%o less than current climatic conditions (Rose and Davisson, 2002), which would produce groundwater recharge less than $-18 \% \delta^{18} \mathrm{O}$, much lighter isotopically than observed in Pahute Mesa groundwater. Using mass balance with discharge estimates to Oasis Valley, and inflow estimates from Kawich Valley and Gold Flat, Rose and Davisson (2002) also produced the isotopic signatures observed in Pahute Mesa groundwater. Their simple mass-balance calculations showed that groundwater turnover rates in these aquifers are too high $(6,400$ years) to store significant amounts of Pleistocene recharge.

Changes in carbon isotopes and major-ion chemistry show a general trend of decreasing ${ }^{14} \mathrm{C}$ with increasing $\delta^{13} \mathrm{C}$ as groundwater flows southward indicating dissolution (and/or isotopic exchange) of carbonate rocks coupled with cation exchange on clay minerals, which removes calcium from solution allowing even more carbonate rock dissolution (Rose and Davisson, 2002). Other processes that change the chemical makeup of groundwater and affect carbon isotopes include addition of $\mathrm{CO}_{2}$ from a deep source and mixing of groundwater with local recharge (Rose and Davisson, 2002; Davisson et al., 1999). Small changes in ${ }^{14} \mathrm{C}$ over more than $100 \mathrm{~km}$ implied mixing with younger groundwater recharge, which maintains nonzero ${ }^{14} \mathrm{C}$ content in regional groundwater.

As described above, there currently isn't consensus on the age of Pahute Mesa groundwater or the climatic conditions that groundwater recharge occurred. Therefore, for this study, groundwater recharge was assumed to occur under current climatic conditions.

\section{Chloride in Pahute Mesa Groundwater used for Modeling}

Because hydrologic and geochemical data can be interpreted such that Pahute Mesa groundwater can be derived from Holocene upgradient groundwater flowing into Pahute Mesa from the north with a component of local recharge from precipitation under current climatic conditions, the CMB method can be used to estimate the amount of recharge occurring locally on Pahute Mesa. The average chloride concentration for Pahute Mesa groundwater, excluding groundwater in western Pahute Mesa that has been impacted by water rock reaction with hydrothermally altered minerals, is $8.2 \mathrm{mg} / \mathrm{L}$. Unsaturated zone water in nearby Rainier Mesa, composed of local precipitation that recently infiltrated, has a very similar average chloride concentration of $8.1 \mathrm{mg} / \mathrm{L}$. Springs on the NNSS are also composed of precipitation that recharged since the last major climate shift and have a similar chloride concentration of $7.5 \mathrm{mg} / \mathrm{L}$. Therefore, the average chloride concentration used to represent Pahute Mesa groundwater for the CMB method is 8.2 with a standard deviation of $1.4 \mathrm{mg} / \mathrm{L}$. 


\section{Runoff from Pahute Mesa}

There is almost certainly some surface runoff from Pahute Mesa during heavy summer thunderstorms, but a reliable value or range of values does not exist. In the calculations, five percent of precipitation is assumed to runoff from Pahute Mesa. Similarly, there are also no estimates of chloride concentration in surface runoff from Pahute Mesa, but two values (3.2 and $4.3 \mathrm{mg} / \mathrm{L}$ ) have been reported for samples collected in the Fortymile Wash drainage basin in the vicinity of Yucca Mountain (Savard, 1996). The mean of these two values $(3.75 \mathrm{mg} / \mathrm{L}$ ) is used in the calculations.

\section{Underflow to Pahute Mesa}

As stated in the Introduction, groundwater flowing through volcanic rocks beneath Pahute Mesa is derived both from recharge on Pahute Mesa and groundwater that enters from Kawich Valley and Gold Flat to the north and northwest. Because the depth to the saturated zone is greater than $500 \mathrm{~m}$ across much of Pahute Mesa, there are no springs, therefore, it is assumed that all flow exits Pahute Mesa as lateral underflow.

Underflow from Kawich Valley to Pahute Mesa is uncertain. As stated in the Introduction (and Table 1), there have been six estimates: $5.55 \times 10^{6} \mathrm{~m}^{3} / \mathrm{yr}$ (Nevada State Engineer, 1971; Blankennagel and Weir, 1973), $4.32 \times 10^{6} \mathrm{~m}^{3} / \mathrm{yr}$ (Rush, 1970), $2.5 \times 10^{6} \mathrm{~m}^{3} / \mathrm{yr}$ (Feeney et al., 1987), $1.65 \times 10^{6} \mathrm{~m}^{3} / \mathrm{yr}$ (Spencer, 1990), and $8.29 \times 10^{6} \mathrm{~m}^{3} / \mathrm{yr}$ (Sadler et al., 1992). Blankennagel and Weir's recharge estimate is based on an approximation of the cross-sectional area of the volcanic rocks contributing to flow and the hydraulic gradient while the recharge estimates of Feeney et al. and Sadler et al. are based up calibration of mixing-cell models using $\delta^{2} \mathrm{H}$ as a tracer and the estimate of Spencer is based upon a mixing-cell model using ${ }^{14} \mathrm{C}$ as a tracer. In addition, a potentiometric contour map (Fenelon et al., 2010) shows a hydraulic head gradient from Rainer Mesa north to Kawich Valley, but no head gradient from Kawich Valley to Pahute Mesa. The range in the seven values (zero [from Fenelon et al. 2010] to $8.29 \times 10^{6} \mathrm{~m}^{3} / \mathrm{yr}$ ) spans forty years of study, but does not trend toward a range of values as they fluctuate over time. Since there is no temporal trend in the estimates, it is assumed that all values are equally valid such that an average underflow to Pahute Mesa from Kawich Valley is calculated using all of the data. The average of all seven values is $3.98 \times 10^{6} \mathrm{~m}^{3} / \mathrm{yr}$. This value is used for underflow from Kawich Valley in the recharge model.

Estimates of underflow from Gold Flat are from the same sources as for Kawich Valley (Table 1): $1.23 \times 10^{6} \mathrm{~m}^{3} / \mathrm{yr}$ (Nevada State Engineer, 1971), $1.48 \times 10^{6} \mathrm{~m}^{3} / \mathrm{yr}$ (Blankennagel and Weir, 1973), $4.32 \times 10^{6} \mathrm{~m}^{3} / \mathrm{yr}$ (Rush, 1970), $2.5 \times 10^{6} \mathrm{~m}^{3} / \mathrm{yr}$ (Feeney et al., 1987), $1.65 \times 10^{6} \mathrm{~m}^{3} / \mathrm{yr}$ (Spencer, 1990), and $2.86 \times 10^{6} \mathrm{~m}^{3} / \mathrm{yr}$ (Sadler et al., 1992). The contour map of Fenelon et al. (2010) shows a hydraulic head gradient from Gold Flat toward Pahute Mesa, but without an estimate of hydraulic conductivity and a cross-sectional flow area, it is difficult to determine a flow rate. Therefore, a mean is calculated from six underflow values (disregarding Fenelon et al.) is $2.34 \times 10^{6} \mathrm{~m}^{3} / \mathrm{yr}$; however, this underflow is through all of Pahute Mesa. As described in the Chloride Mass-Balance Model section, the area in which the calculations are made is east of the Purse Fault, and based upon geometrical considerations, only about 75 percent of the boundary between Gold Flat and the Pahute Mesa is west of the fault. Therefore, it is assumed that underflow from Gold Flat is 25 percent of the average of all flow to Pahute Mesa, or $5.85 \times 10^{5} \mathrm{~m}^{3} / \mathrm{yr}$. 


\section{Chloride Concentration of Underflow from Kawich Valley}

There are no wells in Kawich Valley so the chloride concentration in Kawich Valley groundwater is unknown. The only groundwater chloride data in the area are from springs in the Kawich Range (Figure 22). Chloride concentrations in springs in the Kawich Range were obtained from the UGTA Geochemistry Database, Mizell et al. (2008), and from three springs sampled for this study.

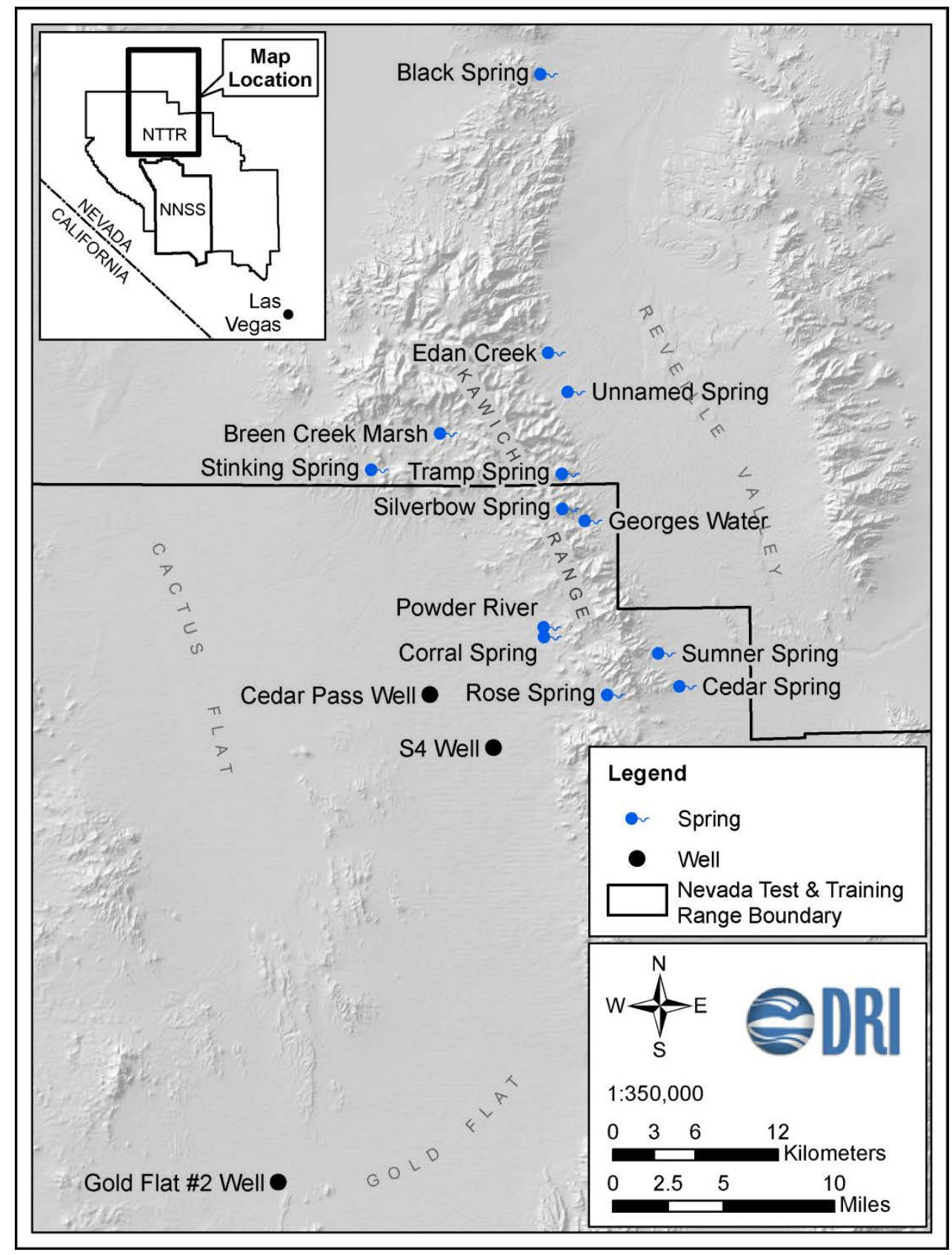

Figure 22. Location of springs in the Kawich Range and wells in Gold Flat. 
Table 9 lists the mean chloride concentration for springs in the Kawich Range showing concentration ranging from 3.4 to $43.9 \mathrm{mg} / \mathrm{L}$. It is often difficult to collect water from springs in semi-arid southern Nevada that has not been evaporated at the discharge point, and as stated earlier, evaporation leads to increases in all dissolved constituents. Spring samples are then sometimes not representative chemically of groundwater recharge. To assess the potential increase in chloride concentrations by evaporation at springs in the Kawich Range, the stable isotopic ratios of water, $\delta^{2} \mathrm{H}$ and $\delta^{18} \mathrm{O}$, were evaluated.

Table 9. Average chloride concentrations, $\delta^{2} \mathrm{H}$, and $\delta^{18} \mathrm{O}$ in springs in the Kawich Range.

\begin{tabular}{lccc}
\hline \multicolumn{1}{c}{ Spring Name } & $\begin{array}{c}\mathrm{Cl} \\
(\mathrm{mg} / \mathrm{L})\end{array}$ & $\begin{array}{c}\delta^{2} \mathrm{H} \\
(\%)\end{array}$ & $\begin{array}{c}\delta^{18} \mathrm{O} \\
(\%)\end{array}$ \\
\hline Unnamed Spring & 3.4 & -99 & -13.3 \\
Georges Water & 4.8 & -98 & -13.2 \\
Breen Creek Marsh & 7.4 & -101 & -13.7 \\
Tramp Spring & 9.8 & -103 & -13.2 \\
Stinking Spring & 18.0 & -103 & -12.9 \\
Sumner Spring & 23.6 & -104 & -13.0 \\
Cedar Spring & 23.9 & -100 & -12.5 \\
Rose Spring & 24.0 & -102 & -12.8 \\
Silverbow Spring & 22.6 & -108 & -13.1 \\
Corral Spring & 36.6 & -104 & -13.4 \\
Powder River Spring & 43.9 & -100 & -12.1 \\
\hline
\end{tabular}

Water that is not evaporated looks isotopically similar to precipitation. On a $\delta^{2} \mathrm{H}$ vs. $\delta^{18} \mathrm{O}$ plot (Figure 23), the local meteoric water line (Thomas et al., 2002; $\delta^{2} \mathrm{H}=7.1 \delta^{18} \mathrm{O}-2.7$; LMWL) represents the range in isotopic signature of precipitation. Groundwater and springs that are not evaporated will plot close to the LMWL while evaporated water will plot right of the LMWL. Only three springs in the Kawich Range plot close to the LMWL, Unnamed, Georges Water, and Breen Creek Marsh. Correspondingly, these samples also have the lowest chloride concentrations. Based on the isotopic signatures of springs, the mean chloride concentration in un-evaporated springs in the Kawich Range is $5.2 \mathrm{mg} / \mathrm{L}$. The number of samples is too small to estimate a standard deviation and standard error; for these three springs, the chloride concentrations range from 3.4 to $7.4 \mathrm{mg} / \mathrm{L}$. The isotopic signature of un-evaporated springs from the Kawich Range and the low chloride concentrations indicates that these waters are representative of local groundwater recharge, but likely not of underflow from Kawich Valley. For this reason, the average chloride concentration of groundwater in Gold Flat was used to represent underflow from Kawich Valley instead of the average chloride concentration of groundwater recharge in Kawich Valley (see discussion below).

\section{Chloride Concentration of Underflow from Gold Flat}

There are three wells in Gold Flat (Figure 22) with water chemistry and isotopic data (Appendix A). Average chloride concentrations (i.e., concentrations from multiple samples collected over years) for these three wells ranges from 5.9 to $15.3 \mathrm{mg} / \mathrm{L}$ (Table 10). One of these 
wells, Gold Flat \#2 Well, has an isotopic signature $\left(\delta^{2} \mathrm{H}=-98 \%\right.$, $\delta^{18} \mathrm{O}=-12.8 \%$ ) that more closely resembles springs (un-evaporated recent groundwater recharge) in the Kawich Range (average of Unnamed Spring, Georges Water Spring, and Breen Creek Marsh Spring: $\delta^{2} \mathrm{H}=-99 \%$, $\delta^{18} \mathrm{O}=-13.4 \%$ ) than the isotopic signature of the other two wells in Gold Flat (S4 Well:

$\delta^{2} \mathrm{H}=-117 \%$, $\delta^{18} \mathrm{O}=-15.1 \%$; Cedar Pass Well: $\delta^{2} \mathrm{H}=-109 \%$ o, $\delta^{18} \mathrm{O}=-13.9 \%$ ) and wells in Pahute Mesa east of the Purse Fault (average $\delta^{2} \mathrm{H}=-113 \%$, $\delta^{18} \mathrm{O}=-14.9 \%$; Table 7 ). Gold Flat \#2 Well has the lowest chloride concentration $(5.9 \mathrm{mg} / \mathrm{L})$ of the three wells in Gold Flat, which is also similar to the average un-evaporated Kawich Range springs chloride concentration (5.2 mg/L). The average chloride concentration for S4 Well and Cedar Pass Well is $12.6 \mathrm{mg} / \mathrm{L}$, which is used to represent the chloride concentration for underflow from Gold Flat and Kawich Valley. Gold Flat \#2 Well was not used to represent underflow from Gold Flat and Kawich valley because of its similarity to springs in the Kawich Range.

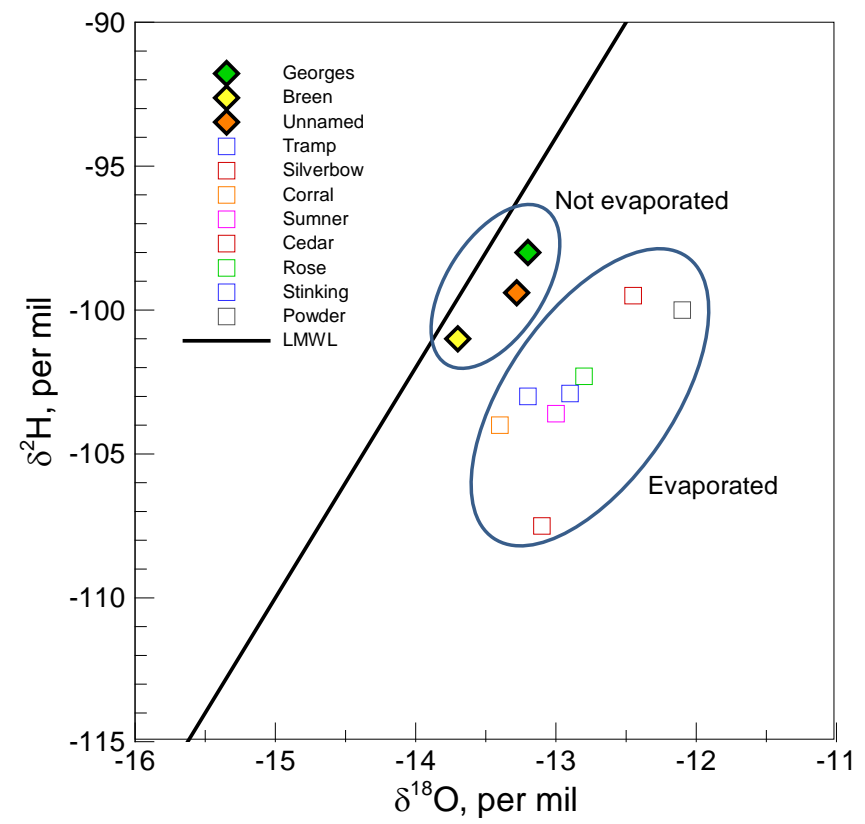

Figure 23. Average stable isotopic composition of springs in the Kawich Range. Springs that plot close to the local meteoric water line (LMWL) are not evaporated (Georges, Breen, Unnamed) while those that plot further from LMWL are evaporated, which corresponds to increased chloride concentration in water samples.

Table 10. Average chloride concentration and isotopic signatures for wells in Gold Flat.

\begin{tabular}{lccc}
\hline & $\begin{array}{c}\mathrm{Cl} \\
(\mathrm{mg} / \mathrm{L})\end{array}$ & $\begin{array}{c}\delta^{2} \mathrm{H} \\
(\%)\end{array}$ & $\begin{array}{c}\delta^{18} \mathrm{O} \\
(\% \circ)\end{array}$ \\
\hline Gold Flat \#2 Well & 5.9 & -98 & -12.8 \\
S4 Well & 9.9 & -117 & -15.1 \\
Cedar Pass Well & 15.3 & -109 & -13.9 \\
\hline
\end{tabular}




\section{RECHARGE CALCULATIONS}

Recharge is estimated by solving (4) for $R$. Because none of the parameters are known exactly, the equation was solved using Monte Carlo techniques, where the calculation was repeated numerous times $(50,000)$, with parameters chosen from a distribution based upon their mean and standard deviation. The data and their uncertainties used in the calculations are presented in Table 11. There was no difference in the mean and standard deviation of the 50,000 calculations when compared with groups of 10,000 calculations chosen from the distribution, meaning that 50,000 calculations is sufficient to determine the true mean and standard deviation of recharge.

Table 11. Mean, standard deviation, and distribution of all input values used in calculations.

\begin{tabular}{|c|c|c|c|}
\hline Variable & Mean & S.D. & Distribution \\
\hline$P, 1800-2000 \mathrm{~m}, \mathrm{~mm} / \mathrm{yr}$ & 200 & 82 & gamma \\
\hline$P,>2000 \mathrm{~m}, \mathrm{~mm} / \mathrm{yr}$ & 281 & 45 & uniform \\
\hline$C_{p}, \mathrm{mg} / \mathrm{L}$ & 0.47 & 0.15 & uniform \\
\hline$C_{r}, \mathrm{mg} / \mathrm{L}$ & 8.2 & 4.1 & uniform \\
\hline$C_{1}$ (Kawich Valley), mg/L & 12.6 & 2.35 & uniform \\
\hline$C_{2}$ (Gold Flat), mg/L & 12.6 & 2.35 & uniform \\
\hline$q_{g w 1}$ (Kawich Valley), $\mathrm{m}^{3} / \mathrm{yr}$ & $3.98 \times 10^{6}$ & $2.07 \times 10^{6}$ & uniform \\
\hline$q_{g w 2}$ (Gold Flat), $\mathrm{m}^{3} / \mathrm{yr}$ & $5.85 \times 10^{5}$ & $1.46 \times 10^{5}$ & uniform \\
\hline$Q_{r o}$, (runoff $1800-2000 \mathrm{~m}$ elev.) $\mathrm{m}^{3} / \mathrm{yr}$ & $2.07 \times 10^{6}$ & $5.18 \times 10^{5}$ & uniform \\
\hline$Q_{\text {ro }}$ ( (runoff $>2000 \mathrm{~m}$ elev.) $\mathrm{m}^{3} / \mathrm{yr}$ & $2.92 \times 10^{6}$ & $7.3 \times 10^{5}$ & uniform \\
\hline$C_{r o}, \mathrm{mg} / \mathrm{L}$ & 3.75 & 0.94 & uniform \\
\hline
\end{tabular}

Because precipitation is significantly different between the Sagebrush and Dead Horse Flat sites, and because the two sites differ in elevation by $142 \mathrm{~m}$, separate calculations are made for each site using the PM1 and A-20 precipitation gauges as proxies for Sagebrush and the A-19 gauge as a proxy for Dead Horse Flat. The elevation of the two sites is $1912 \mathrm{~m}$ and $2054 \mathrm{~m}$ amsl, respectively, so recharge calculations are made for elevations less than $2000 \mathrm{~m}$ and greater than $2000 \mathrm{~m}$. Unfortunately, there are no long-term, reliable precipitation data below $1900 \mathrm{~m}$ on Pahute Mesa, so the lower limit of the Sagebrush calculations extend somewhat arbitrarily to $1800 \mathrm{~m}$. This is based partly on the recharge estimate of Rush (1970) who assumed no recharge on Buckboard Mesa at elevations less than $1829 \mathrm{~m}$ (6000 ft). Mean precipitation at the Sagebrush site (using all of the data from PM1 and A-20) is $200 \mathrm{~mm} / \mathrm{yr}$ while mean precipitation at Dead Horse Flat is $281 \mathrm{~mm} / \mathrm{yr}$. A histogram of annual precipitation at the Sagebrush Site shows that annual precipitation is not normally distributed; rather, annual precipitation in some years can exceed the most frequent value (12 occurrences) by a greater range than the years in which annual precipitation is less than the most frequent value (Figure 24a). The histogram is best fit by a gamma distribution, which was then used in the Monte Carlo calculations. Precipitation values for each calculation were chosen based on the frequency of occurrence. At the Dead Horse Flat site, in contrast, there are only six reliable years of precipitation measurements, which are too few to assign a specific distribution other than uniform (Figure 24b). 

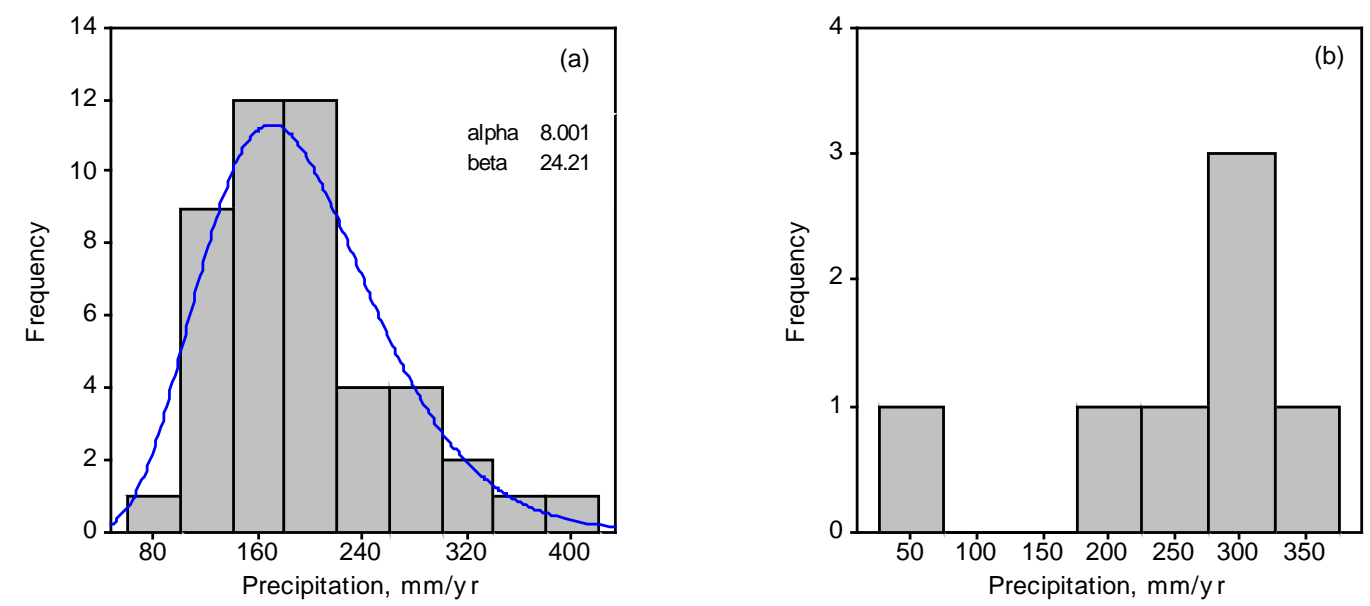

Figure 24. Frequency histogram of annual precipitation at the (a) Sagebrush and (b) Dead Horse Flat sites. The parameters $\alpha$ and $\beta$ in (a) are for the gamma distribution curve shown. In (b) the precipitation value $53.6 \mathrm{~mm} / \mathrm{yr}$ was considered to be unreliable.

Precipitation must be converted into volumetric flow rate $\left(\mathrm{L}^{3} / \mathrm{T}\right)$, which requires a determination of the area over which precipitation falls. The reason is that estimates of underflow from Kawich Valley and Gold Flat to Pahute Mesa are reported as volumetric flow and cannot be converted into a volumetric flux $(\mathrm{L} / \mathrm{T})$ because the cross-sectional area of flow is not clearly known from any of the studies. The area of Pahute Mesa between $1800 \mathrm{~m}$ and $2000 \mathrm{~m}$ amsl is $207 \mathrm{~km}^{2}$, while the area $>2000 \mathrm{~m}$ amsl is $208 \mathrm{~km}^{2}$ (Figure 25). When converted to volume of precipitation per year, this gives precipitation between 1800 and $2000 \mathrm{~m}$ elevation as $4.14 \times 10^{7} \mathrm{~m}^{3} / \mathrm{yr}$ and elevation greater than $2000 \mathrm{~m}$ as $5.84 \times 10^{7} \mathrm{~m}^{3} / \mathrm{yr}$.

None of the other parameters are known with enough certainty to justify assuming a frequency distribution other than uniform in the calculations. For most parameters, there are too few measurements to determine if the parameter values are distributed normally, which is typically assumed. For example, underflow from Kawich Valley and Gold Flat are estimates from models as opposed to being measurements made systematically. In this case, the concept of a mean is tenuous, and standard deviation even more so, because the models are each done differently, with different assumptions, and are therefore biased. For this reason, all estimates were honored with equal weight in the calculations - the mean was calculated by subtracting the lowest value from the highest (this is the range) and dividing by 2 . The standard deviation of a uniform distribution is calculated as by dividing the range by $\sqrt{12}$ (Haan, 1977). The assumption of a uniform distribution, as opposed to a normal one, results in larger uncertainty because equal weight is given to the all values in the distribution. 


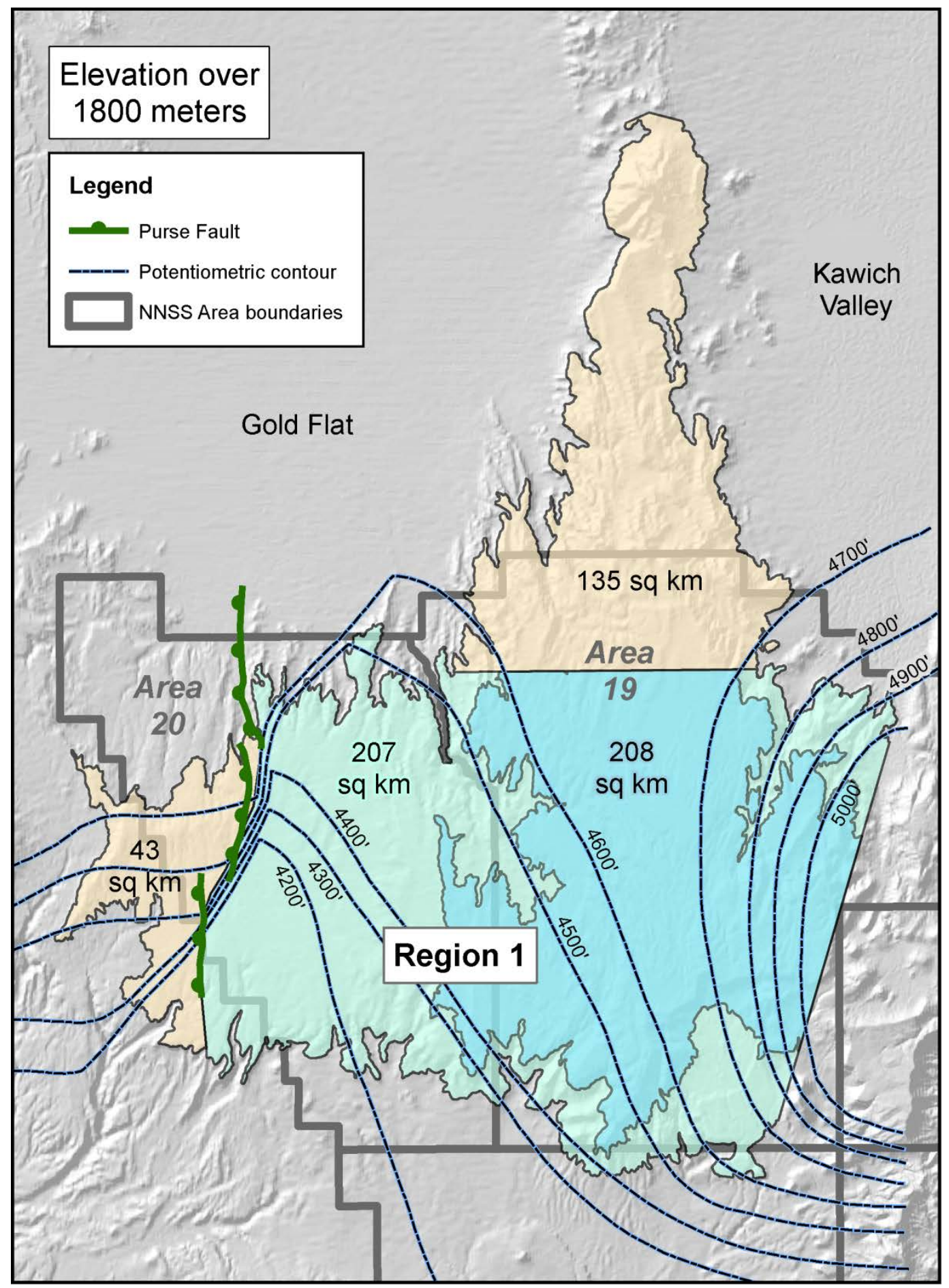

Figure 25. Outline of area higher than 1,800 m elevation amsl at Pahute Mesa. Water-level contours are from Fenelon et al. (2010). 
Figure 26 shows the results of the Monte Carlo recharge calculations, and includes underflow from Kawich Valley and Gold Flat, as well as runoff from Pahute Mesa. The distribution of recharge calculations at both sites follows a gamma distribution, which is interesting because only annual precipitation at the Sagebrush Site was considered to follow a gamma distribution. The mean of a gamma distribution is defined by the shape $(\alpha)$ and scale $(\beta)$ parameters multiplied together (Haan, 1977). At the Sagebrush site, $\alpha$ and $\beta$ are 3.248 and 9.572, respectively, resulting in a mean recharge estimate of $31 \mathrm{~mm} / \mathrm{yr}$. The standard deviation $(\sigma)$ is calculated as $\beta \sqrt{\alpha}$ (Haan, 1977), which results in $\sigma$ of $17 \mathrm{~mm} / \mathrm{yr}$. At the Dead Horse Flat site, $\alpha=3.414$ and $\beta=10.02$; the mean and standard deviation are $34 \mathrm{~mm} / \mathrm{yr}$ and $19 \mathrm{~mm} / \mathrm{yr}$, respectively. Since the values are so close together, and the areas of the representative sites (1800 $\mathrm{m}$ and $2000 \mathrm{~m}$; and >2000 $\mathrm{m}$ amsl) are different by only a square kilometer, recharge on Pahute Mesa, based upon the chloride mass balance method as expressed in equation (4) and the data described here is estimated as $32.5 \mathrm{~mm} / \mathrm{yr}$ with a standard deviation of $18 \mathrm{~mm} / \mathrm{yr}$. The observation that mean recharge is nearly the same at the two sites, with a single difference being $80 \mathrm{~mm} / \mathrm{yr}$ of annual precipitation between the two, indicates that recharge is strongly controlled by other factors than precipitation amount. Of the two factors, evapotranspiration and runoff, ET is the dominant controlling factor as runoff is assumed to be less than 10 percent of precipitation. If recharge is estimated assuming no mixing with groundwater from Kawich Valley or Gold Flat, and no runoff, then the recharge estimates are $7 \mathrm{~mm} / \mathrm{yr}$ with a standard deviation of $5 \mathrm{~mm} / \mathrm{yr}$ for elevations between $1800 \mathrm{~m}$ and $2000 \mathrm{~m}$, and $10 \mathrm{~mm} / \mathrm{yr}$ with a standard deviation of $7 \mathrm{~mm} / \mathrm{yr}$ for elevations $>2000 \mathrm{~m}$.
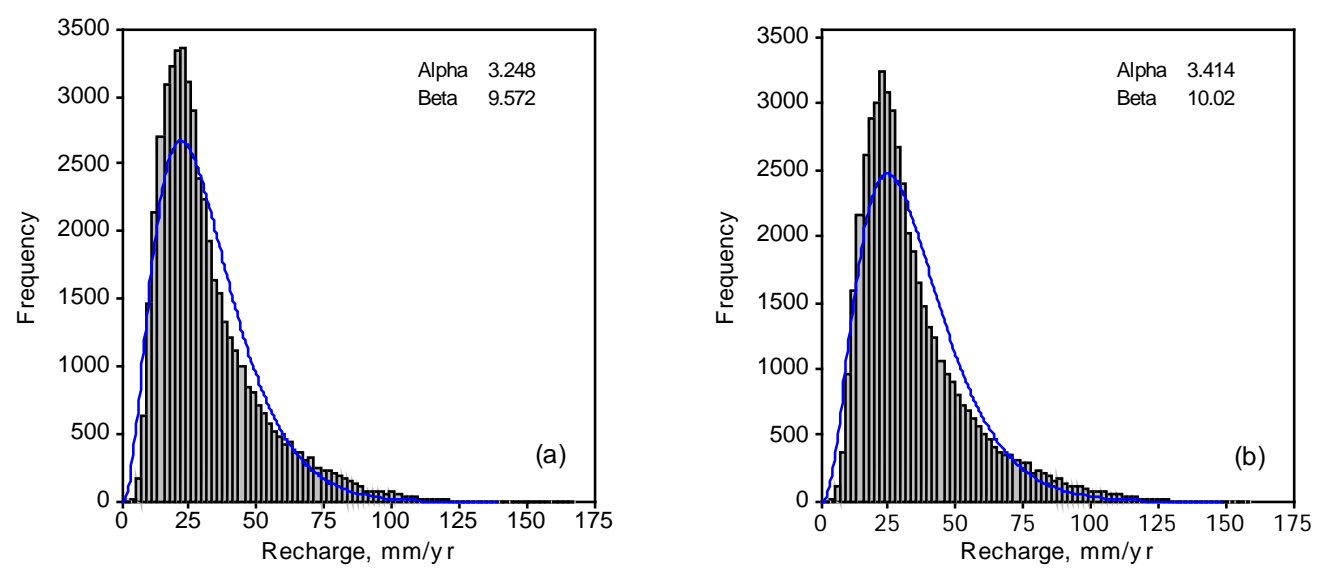

Figure 26. Distribution of recharge at (a) the Sagebrush site (between $1800 \mathrm{~m}$ and $2000 \mathrm{~m}$ amsl), and (b) Dead Horse Flat site (>2000 m) from Monte Carlo calculations. Alpha and beta are the shape and scale parameters of the gamma distribution, respectively. The calculations assume underflow from both Kawich Valley and Gold Flat, as well as runoff from Pahute Mesa. 


\section{DISCUSSION}

Mean recharge on Pahute Mesa is estimated as $30 \mathrm{~mm} / \mathrm{yr}$ amsl with a standard deviation of $18 \mathrm{~mm} / \mathrm{yr}$ for elevations $>1800 \mathrm{~m}$. This is based on a chloride mass balance model that includes underflow from two northern valleys and precipitation runoff. The model considers the best estimates and distributions of precipitation from historical gauges, underflow from Kawich Valley and Gold Flat from existing reports, chloride concentrations in groundwater within Pahute Mesa and from Kawich Valley and Gold Flat, and runoff flow rate and chloride concentration. It also assumes that recharge has occurred within the past 12,000 years. The estimated $30 \mathrm{~mm} / \mathrm{yr}$ recharge represents 15 percent of precipitation for elevations between $1800 \mathrm{~m}$ and $2000 \mathrm{~m}$, and 11 percent for elevations $>2000 \mathrm{~m}$.

For comparison, Rush (1970) estimated recharge at Buckboard Mesa (south of Pahute Mesa) as being seven percent of precipitation. As reported in Stoller-Navarro (2006), Russell and Minor (2002) estimated recharge as between 10 and $50 \mathrm{~mm} / \mathrm{yr}$ for most of Pahute Mesa while the USGS and Pahute Mesa Phase I Flow (numerical) models both estimated recharge to be between 2 and $20 \mathrm{~mm} / \mathrm{yr}$. The results presented here are almost completely consistent with the recharge estimates of Russell and Minor (2002) who did not consider mixing of groundwater from the northern valleys. If mixing and runoff are not considered, recharge is estimated as $7 \mathrm{~mm} / \mathrm{yr}$ (1800 to $2000 \mathrm{~m}$ ) and $10 \mathrm{~mm} / \mathrm{yr}$ (>2000 m), which are in agreement with the USGS and Pahute Mesa Phase I Flow models. An analysis of the data, however, suggests strongly that chloride in wells on Pahute Mesa is a combination of direct recharge on the mesa and mixing with groundwater from Kawich Valley and Gold Flat.

\section{CONCLUSIONS}

Accuracy of the chloride mass-balance model applied to Pahute Mesa is limited by (1) accurate representation of total chloride input (wet and dry deposition) as recharge into the underlying aquifer, (2) determination of the amount of subsurface underflow from Kawich Valley and Gold Flat and the degree in which those flows mix with recharge, (3) evaluation of the chloride concentration of subsurface underflows, and (4) determination of the flow rate and chloride concentration of runoff from Pahute Mesa. With respect to the calculations provided in this report, precipitation estimates are the most certain as they appear valid to within \pm 5 percent based on several decades of data collection. At the other end of the spectrum is the degree of mixing between Pahute Mesa recharge and underflow from Kawich Valley and Gold Flat, which can be anywhere between zero and $8 \times 10^{6} \mathrm{~m}^{3} / \mathrm{yr}$. Groundwater almost certainly flows in volcanic units from Kawich Valley and Gold Flat through Pahute Mesa, but the degree of mixing with Pahute Mesa recharge is unknown and can only be hypothesized. This is difficult in light of a poor understanding of the general concepts of flow through networks of fractures with unknown properties, degree of interconnection, and spatially varying hydraulic head gradients operating over length scales from millimeters to tens or hundreds of meters.

At the most extreme, chloride concentration of recharge, which includes a combination of dry- and wet-deposition, may vary by an order of magnitude, but the true value probably fluctuates between 20 or 30 percent based upon scientific judgment and chloride measurements made in the Basin and Range by other researchers. Dry deposition is probably the least expensive and time-consuming variable whose uncertainty could be reduced; this would require a better 
understanding of the spatial and temporal flow patterns of chloride-containing dust on and off Pahute Mesa and the conditions in which it interacts with the land surface in terms of deposition and (re)suspension into the atmosphere.

The CMB recharge model is based upon data collected east of the Purse Fault and ignores chloride values in groundwater west of the fault as there is strong evidence that chloride in groundwater has reacted with hydrothermally altered volcanic rocks. The recharge estimates, however, are assumed to be applicable to all of Pahute Mesa as any variation in the conditions in which recharge occurs is assumed to be within the uncertainty considered in the model.

Finally, if it is assumed that groundwater beneath Pahute Mesa recharged during the (wetter) Pleistocene, then chloride concentrations in groundwater would be expected to be less than modern-day groundwater chloride concentration. Under this scenario, CMB-derived recharge estimates based upon Pleistocene climatic conditions would be greater than those determined under modern climate conditions. The results presented here should therefore be considered an upper bound for modern recharge estimates. 


\section{REFERENCES}

Anderson, T.W., G.W. Freethey, and P. Tucci, 1992. Geohydrology and Water Resources of Alluvial Basins in South Central Arizona and Parts of Adjacent States. U.S. Geological Survey Professional Paper 1406-B.

Belcher, W.R., and Sweetkind, D.S., eds., 2010. Death Valley Regional Groundwater Flow System, Nevada and California - Hydrogeologic Framework and Transient Groundwater Flow Model. U.S. Geological Survey Professional Paper 1711, 398 p.

Benedict, F.C. Jr., T. P. Rose, and X. Zhou, 2000. Mineralogical, Chemical, and Isotopic Characterization of Fracture-Coating Minerals in Borehole Samples from Western Pahute Mesa and Oasis Valley, Nevada. Lawrence Livermore National Laboratory UCRL-ID-152919.

Blankennagel, R.K., and J.E. Weir, Jr., 1973. Geohydrology of the Eastern Part of Pahute Mesa, Nevada Test Site, Nye County, Nevada. U.S. Geological Survey Professional Paper 712-B, 35 pp.

Brikowski, T., J. Chapman, B. Lyles, S. Hokett, 1993. Origin of Elevated Water Levels Encountered in Pahute Mesa Emplacement Boreholes: Preliminary Investigations. Desert Research Institute Publication No. 45123.

Calhoun, S.C., 2000. Regional Groundwater Flow at the Nevada Test Site using Stable Isotopes and Trace Element Chemistry, unpublished M.S. Thesis, University of Nevada, Reno, 188 pp.

Carroll, R.W.H., G.M. Pohll, S. Earman, and R.L. Hershey, 2007. Global optimization of a deuterium calibrated, discrete-state compartment model (DSCM): Application to the eastern Nevada Test Site. J. Hydrology, v. 345, 237-253.

Carroll, R.W.H., G.M. Pohll, S. Earman, and R.L. Hershey, 2008. A comparison of groundwater fluxes computed with MODFLOW and a mixing model using deuterium: Application to the eastern Nevada Test Site and vicinity. J. Hydrology, 371, 371-385.

Craig, H., 1961. Isotopic variations in meteoric waters. Science, 133, 1702-1703.

Davisson , M.L., D.K. Smith, J. Kenneally, and T.P. Rose, 1999. Isotope hydrology of southern Nevada groundwater: stable isotopes and radiocarbon. Water Resources Research 35, 279-294.

Dettinger, M.D., 1989. Reconnaissance estimates of natural recharge to desert basins in Nevada, U.S.A., by using chloride-balance calculations. J. Hydrology, 106, pp. 55-78.

Drellack, S.L. Jr., L.B. Prothro, and J.L. Gonzales, 2002. A hydrostratigraphic model of the Pahute Mesa - Oasis Valley Area, Nye County, Nevada. 2002 International Groundwater Symposium, March 25-28, Lawrence Berkeley National Laboratory, DOE/NV/11718-646.

Eriksson, E., and V. Khunakasem, 1969. Chloride concentration in groundwater, recharge rate and rate of deposition of chloride in the Israel coastal plain. J. Hydrology, 7, 178-197. 
Feeney, T.A., M.E. Campana, and R.L. Jacobson, 1987. A deuterium-calibrated groundwater flow mode of the western Nevada Test Site and vicinity. Desert Research Institute Publication no. 45057, Las Vegas and Reno, Nevada, also DOE/NV/10384-16, 41 pp. plus two appendices.

Fenelon, J.M., D.S. Sweetkind, and R.J. Laczniak, 2010. Groundwater flow systems at the Nevada Test Site, Nevada: A synthesis of potentiometric contours, hydrostratigraphy, and geologic structures. U.S. Geological Survey Professional Paper 1771, 54 pp.

Ferguson, J.F., A. H. Cogbill, and R. G. Warren, 1994. A geophysical-geological transect of the Silent Canyon Caldera Complex, Pahute Mesa, Nevada. Journal of Geophysical Research, 99, 4323-4339.

Gardner, G.G. and T.H. Brikowski, 1993. The Origin of Elevated Water Levels in Emplacement Boreholes, Pahute Mesa, Nevada Test Site: A Numerical Study. Desert Research Institute, Water Resources Center Publication No. 45124.

Gee, G.W., Z.F. Zhang, S.W. Tyler, W.H. Albright, and M.J. Singleton, 2005. Chloride mass balance: Cautions in predicting increased recharge rates. Vadose Zone Journal, 4, 7278.

Haan, C.T., 1977. Statistical Methods in Hydrology. Iowa State University Press, 378 pp.

Hershey, R.L., S. A. Mizell, and S. Earman, 2010. Chemical and physical characteristics of springs discharging from regional flow systems of the carbonate-rock province of the Great Basin, western United States. Hydrogeology Journal, 18, 1007-1026.

Hershey, R.L., J.B. Paces, M.J. Singleton, E.M. Kwicklis, D.L. Decker, W.M. Fryer, and S. Earman, 2008. Geochemical and Isotopic Evaluation of Groundwater Movement in Corrective Action Unit 99: Rainier Mesa and Shoshone Mountain, Nevada Test Site. Desert Research Institute Publication No. 45229.

Hershey, R.L and T. H. Brikowski, 1995. Continued Investigations of the Occurrence of Water in Pahute Mesa Emplacement Holes. Desert Research Institute Publication No. 45131.

Ingraham, N.L., B.F. Lyles, R.L. Jacobson, and J.W. Hess, 1991. Stable isotopic study of precipitation and spring discharge in southern Nevada. Journal of Hydrology, 125, 243-258.

Ingraham, N.L., R.L. Jacobson, J.W. Hess, and B.F. Lyles, 1990. Stable Isotopic Study of Precipitation and Spring Discharge on the Nevada Test Site. Desert Research Institute Publication No. 45078.

IT, 1998. Summary of Micrographic Analysis of Fracture Coating Phases on Drill Cores from Pahute Mesa, Nevada Test Site. U.S. Department of Energy DOE/NV13052—050Rev.1.

Kwicklis, E.M., T.P. Rose, F.C. Benedict, Jr., 2005. Evaluation of Groundwater Flow in the Pahute Mesa-Oasis Valley Flow System using Groundwater Chemical and Isotopic Data. Los Alamos National Laboratory LA-UR-05-4344. 
Laczniak, R.J., J.C. Cole, D.A. Sawyer, and D.A. Trudeau, 1996. Summary of Hydrogeologic Controls on Ground-Water Flow at the Nevada Test Site, Nye County, Nevada. U.S. Geological Survey Water-Resources Investigation Report 96-4109.

Lyles, B.F, J. Edkins, R.L. Jacobson, and J.W. Hess, 1990. Time-Series Analysis of Ion and Isotope Geochemistry of Selected Springs on the Nevada Test Site, Nye County, Nevada. Desert Research Institute Publication No. 45068.

Maurer, D.K., and D.L. Berger, 1997. Subsurface Flow and Water Yield from Watersheds Tributary to Eagle Valley Hydrographic Area, West-Central Nevada. U.S. Geological Survey Water-Resources Investigation Report 97-4191.

Maxey, G.B., and T.E. Eakin, 1949. Groundwater in White River Valley, White Pine, Nye, and Lincoln Counties, Nevada. Nevada Department of Conservation and Natural Resources Water Resources Bulletin, no. 8.

Meijer, A., 2002. Conceptual model of controls on natural water chemistry at Yucca Mountain, Nevada. Applied Geochemistry 17, 793-805.

Mizell, S.A., T.M. Mihevc, R.L. Hershey, 2008. Field Reconnaissance and Chemistry Data for Selected Water Sources on the Nevada Test and Training Range. Desert Research Institute Publication no. 41247.

Moysey, S., S.N. Davis, M. Zreda, and L.D. Cecil, 2003. The distribution of meteoric ${ }^{36} \mathrm{Cl} / \mathrm{Cl}$ in the United States: a comparison of models, Hydrogeology Journal, 11, 615-627.

Nevada State Engineer, 1971. Nevada's Water Resources. Nevada Division of Water Resources Water for Nevada Report 3.

Phillips, F.M., 2000. Chlorine-36, in Environmental Tracers in Subsurface Hydrology, P.G. Cook, A.L. Herczeg, editors, Kluwer Academic, pp. 299-348.

Rose, T.P., F.C. Benedict, J.M. Thomas, W.S. Sicke, R.L. Hershey, J.B. Paces, I.M. Farnham, and Z.E. Peterman, 2006. Geochemical data analysis and interpretation of the Pahute Mesa - Oasis Valley Groundwater Flow System, August 2002, Nye County, Nevada. Lawrence Livermore National Laboratory rpt. UCRL-TR-224559.

Rose, T.P. and M.L. Davisson, 2002. Isotopic and Geochemical Evidence for Holocene-age Groundwater in Regional Flow Systems of South-Central Nevada. In: T.P. Rose, G.F. Eaton, and R.I. Yamamoto (eds.) Hydrologic Resources Management Program and Underground Test Area Project FY2000 Progress Report, Lawrence Livermore National Laboratory UCRL-ID-14167, 99-139.

Rush, F.E., 1970. Regional Ground-Water Systems in the Nevada Test Site Area, Nye, Lincoln, and Clark Counties, Nevada. State of Nevada, Department of Conservation and Natural Resources, Water Resources-Reconnaissance Series Report 54, 25 pp.

Russell, C.E., S.A. Mizell, and T.B. Minor, 2007. Estimation of groundwater recharge in Steptoe Valley, Nevada, by the elevation-dependent chloride mass-balance approach. Desert Research Institute Publication no. 41241, Las Vegas and Reno, Nevada, 53 pp. 
Russell, C.E., and T. Minor, 2002. Reconnaissance estimates of recharge based on an elevationdependent chloride mass-balance approach. Desert Research Institute Publication no. 45164, Las Vegas and Reno, Nevada, also DOE/NV/11508-37, 57 pp. plus one appendix.

Russell, C.E., 1987. Hydrogeologic Investigation of Flow in Fractured Tuff, Rainier Mesa, Nevada Test Site. Master's Thesis, University of Nevada, Las Vegas.

Sadler, W.R., M.E. Campana, R.L. Jacobson, and N.L. Ingraham, 1992. A deuterium-calibrated, discrete-state compartment model of regional groundwater flow. Nevada Test Site and vicinity. Desert Research Institute Publication no. 45088, Las Vegas and Reno, Nevada, also DOE/NV/10845-09, 77 pp.

Savard, C.S. 1996. Selected Hydrologic Data from Fortymile Wash in the Yucca Mountain Area, Nevada, Water Years 1993-94. U.S. Geological Survey Open-File Report 95-709, 30 pp.

Schoff. S.L., and J.E. Moore, 1964. Chemistry and Movement of Ground Water, Nevada Test Site. U.S. Geological Survey Report TEI-838.

Simpson, E.S., D.B. Thorud, and I. Friedman, 1972. Distinguishing seasonal recharge to groundwater by deuterium analysis in southern Arizona. In: World Water Balance. Proceedings of the Reading Symposium 1970. International Association of Scientific Hydrology-UNESCO-WMO, 623-633.

Spencer, E., 1990. A radiocarbon study of groundwater in the western Nevada Test Site and vicinity, unpublished M.S. Thesis, University of Nevada, Reno, 124 pp.

Stoller-Navarro Joint Venture and Los Alamos National Laboratory, 2009. Phase I Transport Model of Corrective Action Units 101 and 102: Central and Western Pahute Mesa, Nevada Test Site, Nye County, Nevada. S-N/99205-111.

Stoller-Navarro Joint Venture and National Securities Technologies, LLC, 2008. Phase I Hydrologic Data for the Groundwater Flow and Contaminant Transport Model of Corrective Action Unit 99: Rainier Mesa/Shoshone Mountain, Nevada Test Site, Nye County, Nevada. S-N/99205-103.

Stoller-Navarro Joint Venture and Los Alamos National Laboratory, 2006. Groundwater Flow Model of Corrective Action Units 101 and 102: Central and Western Pahute Mesa, Nevada Test Site, Nye County, Nevada. S-N/99205-076.

Thomas, J. M. and W.H. Albright, 2003. Estimated Groundwater Recharge to Dry Valley, Northwestern Nevada, using the Chloride Mass Balance Method. Desert Research Institute Publication no. 41191, Las Vegas and Reno, 25 pp.

Thomas, J.M., F.C. Benedict, T.P. Rose, R.L. Hershey, J.B. Paces, Z.E. Peterman, I.M. Farnham, K.H. Johannesson, A.K. Singh, K.J. Stetzenbach, G.B. Hudson, J.M. Kenneally, G.F. Eaton, and D.K. Smith, 2002. Geochemical and Isotopic Interpretations of Groundwater flow in the Oasis Valley Flow System, Southern Nevada. Desert Research Institute Publication no. 45190, Las Vegas and Reno, also DOE/NV/150856,102 pp. 
Tyler, S.W., J.B. Chapman, S.H. Conrad, D.P. Hammermeister, D.O. Blout, J.J. Miller, M.J. Sully, and J.M. Ginanni, 1996. Soil-water flux in the southern Great Basin, United States: Temporal and spatial variations over the last 120,000 years. Water Resources Research, 32(6), 1481-1499.

U.S. Department of Energy, 2009. Phase II Corrective Action Investigation Plan for Corrective Action Units 101 and 102: Central and Western Pahute Mesa, Nevada Test Site, Nye County, Nevada. DOE/NV-1312-Rev. 2.

U.S. Geological Survey, 2008.Documentation of computer program INFIL3.0-A distributedparameter watershed model to estimate net infiltration below the root zone. U.S. Geological Survey Scientific Investigations Report 2008-5006, 98 p. (Online only)

Wilson, J.L., and H. Guan, 2004. Mountain-block hydrology and mountain-front recharge, in Groundwater Recharge in a Desert Environment: The Southwestern United States, edited by J.F. Hogan, F.M. Phillips, and B.R. Scanlon, American Geophysical Union, Washington, D.C. 
THIS PAGE INTENTIONALLY LEFT BLANK 
APPENDIX A. Chloride, Sulfate, and Isotopic Data.

\begin{tabular}{|c|c|c|c|c|c|c|c|c|}
\hline Well Name & Latitude & Longitude & Date & $\begin{array}{c}\mathrm{Cl} \\
(\mathrm{mg} / \mathrm{L})\end{array}$ & $\begin{array}{c}\mathrm{SO}_{4} \\
(\mathrm{mg} / \mathrm{L})\end{array}$ & $\begin{array}{l}\delta^{2} H \\
(\% o) \\
\end{array}$ & $\begin{array}{c}\delta^{18} O \\
(\% o) \\
\end{array}$ & Reference \\
\hline \multicolumn{9}{|l|}{ AREA 20} \\
\hline \multirow[t]{6}{*}{ ER-20-4 } & 371143 & 1162625 & 9/20/2011 & 4.7 & 17.0 & & & UGTA Geochem DB - N-I \\
\hline & & & 9/20/2011 & 4.6 & 17.0 & & & UGTA Geochem DB - N-I \\
\hline & & & average N-I & 4.7 & 17.0 & & & \\
\hline & & & $9 / 21 / 2011$ & 4.8 & 16.7 & -116 & -15.3 & UGTA Geochem DB - LLNL \\
\hline & & & $9 / 21 / 2011$ & & & -114 & -14.9 & DRI \\
\hline & & & average & 4.7 & 16.9 & -115 & -15.1 & \\
\hline \multirow[t]{16}{*}{ ER-20-5 \#3 } & 371312 & 1162838 & $4 / 26 / 2011$ & & & -118 & -15.7 & UGTA Geochem DB - LLNL \\
\hline & & & $11 / 29 / 2004$ & 17.4 & 35.5 & -114 & -15.1 & UGTA Geochem DB - LLNL \\
\hline & & & $11 / 15 / 2001$ & 18.9 & 35.3 & -114 & -15.0 & UGTA Geochem DB - LLNL \\
\hline & & & $4 / 30 / 1998$ & & & -113 & -15.1 & UGTA Geochem DB - DRI \\
\hline & & & $4 / 30 / 1998$ & 17.3 & 33.3 & & & UGTA Geochem DB - LLNL \\
\hline & & & 4/30/1998 & 15.6 & 33.2 & & & UGTA Geochem DB - IT \\
\hline & & & average 4/30/1998 & 16.5 & 33.3 & & & \\
\hline & & & $4 / 22 / 1997$ & 15.4 & 31.4 & & & UGTA Geochem DB - IT \\
\hline & & & $4 / 22 / 1997$ & & & & -15.1 & UGTA Geochem DB - LLNL \\
\hline & & & 4/4/1997 & & & -113 & -15.1 & UGTA Geochem DB - DRI \\
\hline & & & 7/31/1996 & 17.5 & 34.6 & & & UGTA Geochem DB - IT \\
\hline & & & 7/31/1996 & 17.5 & 34.6 & & & UGTA Geochem DB - IT \\
\hline & & & 7/31/1996 & & & -114 & -15.2 & UGTA Geochem DB - LLNL \\
\hline & & & $7 / 31 / 1996$ & & & -115 & -15.1 & UGTA Geochem DB - LLNL \\
\hline & & & average 7/31/1996 & 17.5 & 34.6 & -115 & -15.2 & \\
\hline & & & average & 17.1 & 34.0 & -114 & -15.2 & \\
\hline \multirow[t]{6}{*}{ ER-20-6 \#3 } & 371533 & 1162518 & $5 / 13 / 1998$ & & & -113 & -14.9 & UGTA Geochem DB - DRI \\
\hline & & & $5 / 13 / 1998$ & 11.9 & 30.5 & -115 & -15.0 & UGTA Geochem DB - LLNL \\
\hline & & & $5 / 13 / 1998$ & 11.4 & 30.4 & & & UGTA Geochem DB - IT \\
\hline & & & average 5/13/1998 & 11.7 & 30.5 & -114 & -15.0 & \\
\hline & & & $7 / 17 / 1997$ & 13.3 & 33.6 & -114 & -15.0 & UGTA Geochem DB - LLNL \\
\hline & & & 6/6/1997 & 11.1 & 29.0 & & & UGTA Geochem DB - HRCES \\
\hline
\end{tabular}


APPENDIX A. Chloride, Sulfate, and Isotopic Data (continued).

\begin{tabular}{|c|c|c|c|c|c|c|c|c|}
\hline Well Name & Latitude & Longitude & Date & $\begin{array}{c}\mathrm{Cl} \\
(\mathrm{mg} / \mathrm{L})\end{array}$ & $\begin{array}{c}\mathrm{SO}_{4} \\
(\mathrm{mg} / \mathrm{L})\end{array}$ & $\begin{array}{l}\delta^{2} H \\
(\% o) \\
\end{array}$ & $\begin{array}{c}\delta^{18} O \\
(\% o)\end{array}$ & Reference \\
\hline \multirow[t]{9}{*}{ ER-20-6 \#3 (cont.) } & & & 6/6/1997 & 11.4 & 29.0 & & & UGTA Geochem DB - HRCES \\
\hline & & & average 6/6/1997 & 11.3 & 29.0 & & & \\
\hline & & & 6/2/1997 & & & & -15.1 & UGTA Geochem DB - LLNL \\
\hline & & & 12/16/1996 & 13.6 & 31.8 & -115 & -15.0 & UGTA Geochem DB - LLNL \\
\hline & & & $12 / 16 / 1996$ & 13.9 & 32.2 & & & UGTA Geochem DB - IT \\
\hline & & & average 12/16/1996 & 13.8 & 32.0 & & & \\
\hline & & & 12/4/1996 & & & -111 & -15.0 & UGTA Geochem DB - DRI \\
\hline & & & average 1996 & & & -113 & -15.0 & \\
\hline & & & average & 12.5 & 31.3 & -114 & -15.0 & \\
\hline \multirow[t]{5}{*}{ ER-20-7 } & 371247 & 1162845 & $9 / 24 / 2010$ & 30.0 & 53.0 & & & UGTA Geochem DB - N-I \\
\hline & & & 9/24/2010 & 31.0 & 53.0 & & & UGTA Geochem DB - N-I \\
\hline & & & average N-I & 30.5 & 53.0 & & & \\
\hline & & & $9 / 24 / 2010$ & 29.7 & 49.6 & -113 & -15.4 & UGTA Geochem DB - LLNL \\
\hline & & & average & 30.1 & 51.3 & & & \\
\hline \multirow[t]{6}{*}{ ER-20-8 \#2 } & 371135 & 1162827 & $12 / 18 / 2009$ & 26.0 & 49.0 & & & UGTA Geochem DB - N-I \\
\hline & & & $12 / 18 / 2009$ & 26.0 & 49.0 & & & UGTA Geochem DB - N-I \\
\hline & & & average N-I & 26.0 & 49.0 & & & \\
\hline & & & $12 / 18 / 2009$ & 28.9 & 51.8 & -117 & -15.4 & UGTA Geochem DB - LLNL \\
\hline & & & $12 / 18 / 2009$ & & & -115 & -15.2 & UGTA Geochem DB - DRI \\
\hline & & & average & 27.5 & 50.4 & -116 & -15.3 & \\
\hline \multirow[t]{5}{*}{ ER-20-8 Int } & 371135 & 1162826 & $6 / 27 / 2011$ & 33.0 & 50.0 & & & UGTA Geochem DB - N-I \\
\hline & & & $6 / 27 / 2011$ & 28.0 & 49.0 & & & UGTA Geochem DB - N-I \\
\hline & & & average N-I & 30.5 & 49.5 & & & \\
\hline & & & $6 / 27 / 2011$ & 28.3 & 49.9 & & & UGTA Geochem DB - LLNL \\
\hline & & & average & 29.4 & 49.7 & & & \\
\hline \multirow[t]{5}{*}{ ER-20-8 Deep } & 371135 & 1162826 & 8/8/2011 & 23.0 & 43.0 & & & UGTA Geochem DB - N-I \\
\hline & & & 8/8/2011 & 24.0 & 42.0 & & & UGTA Geochem DB - N-I \\
\hline & & & average N-I & 23.5 & 42.5 & & & \\
\hline & & & $8 / 8 / 2011$ & 23.8 & 44.5 & & & UGTA Geochem DB - LLNL \\
\hline & & & average & 23.7 & 43.5 & & & \\
\hline
\end{tabular}


APPENDIX A. Chloride, Sulfate, and Isotopic Data (continued).

\begin{tabular}{|c|c|c|c|c|c|c|c|c|}
\hline Well Name & Latitude & Longitude & Date & $\begin{array}{c}\mathrm{Cl} \\
(\mathrm{mg} / \mathrm{L})\end{array}$ & $\begin{array}{c}\mathrm{SO}_{4} \\
(\mathrm{mg} / \mathrm{L})\end{array}$ & $\begin{array}{l}\delta^{2} H \\
(\% o)\end{array}$ & $\begin{array}{c}\delta^{18} O \\
(\% o)\end{array}$ & Reference \\
\hline \multirow[t]{14}{*}{ PM-3 } & 371421 & 1163337 & $10 / 28 / 1988$ & 97.5 & 124.0 & -116 & -15.0 & UGTA Geochem DB - DRI \\
\hline & & & 10/28/1988 & 98.0 & 130.0 & & & UGTA Geochem DB - DRI \\
\hline & & & average 10/28/1988 & 97.8 & 127.0 & & & \\
\hline & & & 10/27/1988 & 95.0 & 122.0 & -116 & -15.1 & UGTA Geochem DB - DRI \\
\hline & & & $10 / 27 / 1988$ & 97.0 & 123.0 & -116 & -15.0 & UGTA Geochem DB - DRI \\
\hline & & & average 10/27/1988 & 96.0 & 122.5 & -116 & -15.1 & \\
\hline & & & 9/27/1988 & 98.9 & 131.0 & -116 & -15.1 & UGTA Geochem DB - DRI \\
\hline & & & 9/27/1988 & 99.3 & 130.0 & -115 & -15.0 & UGTA Geochem DB - DRI \\
\hline & & & 9/27/1988 & & & -114 & & \\
\hline & & & average 9/27/1988 & 99.1 & 130.5 & -115 & -15.1 & \\
\hline & & & 9/26/1988 & 98.1 & 129.0 & -117 & -15.0 & UGTA Geochem DB - DRI \\
\hline & & & $9 / 26 / 1988$ & & & & -14.9 & UGTA Geochem DB - DRI \\
\hline & & & average 9/26/1988 & & & & -15.0 & \\
\hline & & & average & 97.7 & 127.3 & -116 & -15.0 & \\
\hline \multirow[t]{13}{*}{ U-20 Water Well } & 371505 & 1162545 & $11 / 5 / 1997$ & 11.0 & 31.0 & & & UGTA Geochem DB - HRCES \\
\hline & & & $11 / 5 / 1997$ & 11.1 & 31.0 & & & UGTA Geochem DB - HRCES \\
\hline & & & average HRCES & 11.1 & 31.0 & & & \\
\hline & & & $11 / 5 / 1997$ & 12.1 & 31.5 & -113 & -14.7 & UGTA Geochem DB - DRI \\
\hline & & & average $11 / 5 / 1997$ & 11.6 & 31.3 & & & \\
\hline & & & $5 / 31 / 1995$ & 10.6 & 27.1 & & & UGTA Geochem DB - IT \\
\hline & & & 5/31/1995 & 12.0 & & & & UGTA Geochem DB - LLNL \\
\hline & & & average 5/31/1995 & 11.3 & 27.1 & & & \\
\hline & & & 9/11/1990 & 11.4 & 30.7 & & & UGTA Geochem DB - DRI \\
\hline & & & 8/2/1990 & 11.4 & 30.7 & & & UGTA Geochem DB - DRI \\
\hline & & & 4/16/1990 & 11.9 & 28.9 & & & UGTA Geochem DB - DRI \\
\hline & & & $5 / 23 / 1987$ & 12.0 & 31.4 & & & UGTA Geochem DB - DRI \\
\hline & & & average & 11.6 & 30.0 & & & \\
\hline
\end{tabular}


APPENDIX A. Chloride, Sulfate, and Isotopic Data (continued).

\begin{tabular}{|c|c|c|c|c|c|c|c|c|}
\hline Well Name & Latitude & Longitude & Date & $\begin{array}{c}\mathrm{Cl} \\
(\mathrm{mg} / \mathrm{L})\end{array}$ & $\begin{array}{c}\mathrm{SO}_{4} \\
(\mathrm{mg} / \mathrm{L})\end{array}$ & $\begin{array}{l}\delta^{2} H \\
(\%)\end{array}$ & $\begin{array}{c}\delta^{18} O \\
(\% o)\end{array}$ & Reference \\
\hline U-20bg & 371414 & 1162429 & $6 / 27 / 2011$ & 6.6 & 14.8 & -107 & -13.7 & DRI \\
\hline \multirow[t]{30}{*}{ U-20n PS 1DD-H } & 371425 & 1162524 & $11 / 15 / 2005$ & 12.0 & 33.2 & -114 & -14.9 & UGTA Geochem DB - LLNL \\
\hline & & & $7 / 9 / 2003$ & 10.9 & 27.9 & -114 & -15.0 & UGTA Geochem DB - LLNL \\
\hline & & & 10/12/1999 & 11.1 & 28.2 & -113 & -15.0 & UGTA Geochem DB - LLNL \\
\hline & & & 9/21/1998 & 11.3 & 28.0 & -113 & -14.9 & UGTA Geochem DB - LLNL \\
\hline & & & 9/21/1998 & 13.0 & 34.0 & & & UGTA Geochem DB - IT \\
\hline & & & average 9/21/1998 & 12.2 & 31.0 & & & \\
\hline & & & 7/28/1998 & 11.6 & 28.1 & -113 & -15.0 & UGTA Geochem DB - LLNL \\
\hline & & & 7/23/1997 & 11.9 & 26.5 & & -15.0 & UGTA Geochem DB - LLNL \\
\hline & & & $7 / 22 / 1997$ & & & & -14.8 & UGTA Geochem DB - LLNL \\
\hline & & & $7 / 22 / 1997$ & & & & -14.8 & UGTA Geochem DB - LLNL \\
\hline & & & 7/22/1997 & & & & -14.8 & UGTA Geochem DB - LLNL \\
\hline & & & average 7/22/1997 & & & & -14.8 & \\
\hline & & & 6/19/1996 & & & & -14.9 & UGTA Geochem DB - LLNL \\
\hline & & & 6/18/1996 & & & & -14.6 & UGTA Geochem DB - LLNL \\
\hline & & & 5/9/1985 & & & -112 & -14.4 & UGTA Geochem DB - LLNL \\
\hline & & & $10 / 25 / 1984$ & & & -113 & -14.8 & UGTA Geochem DB - LLNL \\
\hline & & & 10/25/1984 & & & & -14.8 & UGTA Geochem DB - LLNL \\
\hline & & & average 10/25/84 & & & & -14.8 & \\
\hline & & & $10 / 23 / 1984$ & & & -110 & -14.1 & UGTA Geochem DB - LLNL \\
\hline & & & 10/3/1984 & & & -113 & -14.9 & UGTA Geochem DB - LLNL \\
\hline & & & 9/26/1984 & & & -110 & -14.9 & UGTA Geochem DB - LLNL \\
\hline & & & 9/19/1984 & & & -114 & -14.6 & UGTA Geochem DB - LLNL \\
\hline & & & 9/12/1984 & & & -113 & -14.9 & UGTA Geochem DB - LLNL \\
\hline & & & $9 / 12 / 1984$ & & & -113 & & UGTA Geochem DB - LLNL \\
\hline & & & average 9/12/84 & & & -113 & & \\
\hline & & & 9/9/1983 & & & -114 & -14.1 & UGTA Geochem DB - LLNL \\
\hline & & & 9/24/1976 & & & -96 & -8.6 & UGTA Geochem DB - LLNL \\
\hline & & & 9/24/1976 & & & -97 & & UGTA Geochem DB - LLNL \\
\hline & & & average 9/24/84 & & & -97 & & \\
\hline & & & average & 11.5 & 28.8 & -112 & -14.4 & \\
\hline
\end{tabular}


APPENDIX A. Chloride, Sulfate, and Isotopic Data (continued).

\begin{tabular}{|c|c|c|c|c|c|c|c|c|}
\hline Well Name & Latitude & Longitude & Date & $\begin{array}{c}\mathrm{Cl} \\
(\mathrm{mg} / \mathrm{L})\end{array}$ & $\begin{array}{c}\mathrm{SO}_{4} \\
(\mathrm{mg} / \mathrm{L})\end{array}$ & $\begin{array}{l}\delta^{2} H \\
(\% o)\end{array}$ & $\begin{array}{l}\delta^{18} O \\
(\% o)\end{array}$ & Reference \\
\hline \multirow[t]{5}{*}{ UE-20bh \#1 } & 371442 & 1162433 & $12 / 8 / 1999$ & 3.5 & 8.3 & -110 & -14.7 & UGTA Geochem DB - DRI \\
\hline & & & 6/20/1993 & 3.9 & 1.0 & -109 & -14.7 & UGTA Geochem DB - LLNL \\
\hline & & & 9/30/1991 & & & -113 & -15.0 & UGTA Geochem DB - DRI \\
\hline & & & 9/11/1991 & 4.7 & 14.0 & -118 & -15.5 & UGTA Geochem DB - DRI \\
\hline & & & average & 4.0 & 7.8 & -113 & -15.0 & \\
\hline \multicolumn{9}{|l|}{ AREA 19} \\
\hline U-19bh & 371349 & 1162220 & 6/28/2011 & 8.6 & 22.8 & -102 & -13.5 & DRI \\
\hline U-19bj & 371736 & 1161847 & $6 / 28 / 2011$ & 15.7 & 27.5 & -101 & -13.5 & DRI \\
\hline U-19bk & 371714 & 1162303 & $6 / 27 / 2011$ & 4.8 & 8.4 & -115 & -15.0 & DRI \\
\hline \multirow[t]{5}{*}{ UE-19c Water Well } & 371608 & 1161910 & 8/13/1992 & 3.1 & & & -15.0 & UGTA Geochem DB - LLNL \\
\hline & & & $9 / 11 / 1990$ & 2.4 & 6.2 & & & UGTA Geochem DB - DRI \\
\hline & & & 8/2/1990 & 2.4 & 5.8 & & & UGTA Geochem DB - DRI \\
\hline & & & 4/16/1990 & 2.6 & 6.6 & -111 & -15.4 & UGTA Geochem DB - DRI \\
\hline & & & average & 2.6 & 6.2 & & -15.2 & \\
\hline \multirow[t]{10}{*}{ UE-19gS } & 371830 & 1162153 & 7/8/1995 & 8.7 & 35.0 & & & UGTA Geochem DB - DRI \\
\hline & & & 1/16/1995 & 14.0 & 38.0 & & & UGTA Geochem DB - DRI \\
\hline & & & 7/9/1974 & 22.0 & 43.0 & & & UGTA Geochem DB - DRI \\
\hline & & & $7 / 3 / 1973$ & 8.4 & 36.0 & & & UGTA Geochem DB - DRI \\
\hline & & & 10/6/1971 & 8.9 & 75.0 & & & UGTA Geochem DB - USGS \\
\hline & & & 3/20/1971 & 9.9 & 100.0 & & & UGTA Geochem DB - USGS \\
\hline & & & 8/2/1966 & 22.0 & 43.0 & & & UGTA Geochem DB - USGS \\
\hline & & & 3/27/1965 & 9.0 & 36.0 & & & UGTA Geochem DB - USGS \\
\hline & & & & & & -114 & -14.5 & $\begin{array}{l}\text { UGTA Geochem DB - White and Chuma } \\
\text { (1987) }\end{array}$ \\
\hline & & & average & 12.9 & 50.8 & & & \\
\hline \multirow[t]{4}{*}{ UE-19h } & 372034 & 1162225 & 12/11/1999 & 9.7 & 38.2 & -110 & -14.4 & UGTA Geochem DB - DRI \\
\hline & & & 8/12/1992 & 8.5 & & & -14.8 & UGTA Geochem DB - LLNL \\
\hline & & & 8/12/1992 & & & -112 & -14.8 & UGTA Geochem DB - DRI \\
\hline & & & average & 9.1 & 38.2 & -111 & -14.7 & \\
\hline
\end{tabular}


APPENDIX A. Chloride, Sulfate, and Isotopic Data (continued).

\begin{tabular}{|c|c|c|c|c|c|c|c|c|}
\hline Well Name & Latitude & Longitude & Date & $\begin{array}{c}\mathrm{Cl} \\
(\mathrm{mg} / \mathrm{L})\end{array}$ & $\begin{array}{c}\mathrm{SO}_{4} \\
(\mathrm{mg} / \mathrm{L})\end{array}$ & $\begin{array}{l}\delta^{2} H \\
(\%)\end{array}$ & $\begin{array}{l}\delta^{18} O \\
(\% o)\end{array}$ & Reference \\
\hline \multicolumn{9}{|l|}{ WEST OF NNSS } \\
\hline \multirow[t]{20}{*}{ ER-EC-1 } & 371223 & 1163147 & $4 / 3 / 2009$ & 93.8 & 118.2 & -116 & -15.0 & UGTA Geochem DB - LLNL \\
\hline & & & $4 / 3 / 2009$ & & & -116 & -14.9 & UGTA Geochem DB - DRI \\
\hline & & & average 4/3/2009 & & & -116 & -15.0 & \\
\hline & & & $4 / 2 / 2009$ & 100 & 120 & & & UGTA Geochem DB - N-I \\
\hline & & & $4 / 2 / 2009$ & 97.0 & 120 & & & UGTA Geochem DB - N-I \\
\hline & & & average 4/2/2009 & 98.5 & 120 & & & \\
\hline & & & average 2009 & 96.2 & 119 & & & \\
\hline & & & $6 / 3 / 2003$ & 92.0 & 110 & & & UGTA Geochem DB - SNJV \\
\hline & & & $6 / 3 / 2003$ & 95.0 & 110 & & & UGTA Geochem DB - SNJV \\
\hline & & & average SNJV & 93.5 & 110 & & & \\
\hline & & & 6/3/2003 & 97.0 & 119 & -116 & -14.9 & UGTA Geochem DB - LLNL \\
\hline & & & 6/3/2003 & 87.7 & 121 & -114 & -14.7 & UGTA Geochem DB - DRI \\
\hline & & & $6 / 3 / 2003$ & & & -116 & -14.9 & UGTA Geochem DB - DRI \\
\hline & & & average DRI & & & -115 & -14.8 & \\
\hline & & & average 2003 & 92.7 & 117 & -116 & -14.9 & \\
\hline & & & $2 / 1 / 2000$ & 97.0 & 145 & -116 & -14.8 & UGTA Geochem DB - LLNL \\
\hline & & & $2 / 1 / 2000$ & 95.0 & 145 & -114 & -14.8 & UGTA Geochem DB - DRI \\
\hline & & & $2 / 1 / 2000$ & & 120 & & & UGTA Geochem DB - IT \\
\hline & & & average 2000 & 96.0 & 137 & -115 & -14.8 & \\
\hline & & & average & 95.0 & 124 & -116 & -14.9 & \\
\hline \multirow[t]{15}{*}{ ER-EC-2A } & 370852 & 1163405 & $5 / 20 / 2010$ & 59.0 & 89.0 & & & UGTA Geochem DB - N-I \\
\hline & & & $5 / 20 / 2010$ & 58.0 & 90.0 & & & UGTA Geochem DB - N-I \\
\hline & & & average 2010 & 58.5 & 89.5 & & & \\
\hline & & & $7 / 8 / 2003$ & 61.0 & 88.0 & & & UGTA Geochem DB - SNJV \\
\hline & & & $7 / 8 / 2003$ & 60.0 & 88.0 & & & UGTA Geochem DB - SNJV \\
\hline & & & average SNJV & 60.5 & 88.0 & & & \\
\hline & & & $7 / 8 / 2003$ & 55.5 & 84.5 & -117 & -14.9 & UGTA Geochem DB - LLNL \\
\hline & & & $7 / 8 / 2003$ & 54.1 & 90.1 & -113 & -14.9 & UGTA Geochem DB - DRI \\
\hline & & & $7 / 8 / 2003$ & & & -117 & -15.0 & UGTA Geochem DB - DRI \\
\hline & & & average DRI & & & -115 & -15.0 & \\
\hline & & & average 2003 & 56.7 & 87.5 & -116 & -14.9 & \\
\hline & & & $7 / 27 / 2000$ & 59.0 & 95.0 & & & UGTA Geochem DB - IT \\
\hline & & & $7 / 27 / 2000$ & 63.0 & 99.0 & -116 & -14.9 & UGTA Geochem DB - LLNL \\
\hline & & & average 2000 & 61.0 & 97.0 & & & \\
\hline & & & average & 58.7 & 91.3 & -116 & -14.9 & \\
\hline
\end{tabular}


APPENDIX A. Chloride, Sulfate, and Isotopic Data (continued).

\begin{tabular}{|c|c|c|c|c|c|c|c|c|}
\hline Well Name & Latitude & Longitude & Date & $\begin{array}{c}\mathrm{Cl} \\
(\mathrm{mg} / \mathrm{L})\end{array}$ & $\begin{array}{c}\mathrm{SO}_{4} \\
(\mathrm{mg} / \mathrm{L})\end{array}$ & $\begin{array}{l}\delta^{2} H \\
(\% o) \\
\end{array}$ & $\begin{array}{c}\delta^{18} O \\
(\% o)\end{array}$ & Reference \\
\hline \multirow[t]{12}{*}{ ER-EC-4 } & 370935 & 1163753 & 6/24/2003 & 82.0 & 110 & & & UGTA Geochem DB - SNJV \\
\hline & & & $6 / 24 / 2003$ & 83.0 & 110 & & & UGTA Geochem DB - SNJV \\
\hline & & & average SNJV & 82.5 & 110 & & & \\
\hline & & & 6/24/2003 & 80.6 & 109 & -114 & -15 & UGTA Geochem DB - LLNL \\
\hline & & & $6 / 24 / 2003$ & 77.6 & 114 & -112 & -14.6 & UGTA Geochem DB - DRI \\
\hline & & & $6 / 24 / 2003$ & & & -114 & -14.7 & UGTA Geochem DB - DRI \\
\hline & & & average DRI & & & -113 & -14.7 & \\
\hline & & & average 2003 & 80.2 & 111 & -114 & -14.6 & \\
\hline & & & $8 / 17 / 2000$ & 84.0 & 120 & & & UGTA Geochem DB - IT \\
\hline & & & $8 / 17 / 2000$ & 95.7 & 130 & -115 & -14.6 & UGTA Geochem DB - LLNL \\
\hline & & & average 2000 & 89.9 & 125 & & & \\
\hline & & & average & 85.0 & 118 & -114 & -14.6 & \\
\hline \multirow[t]{19}{*}{ ER-EC-6 } & 371120 & 1162948 & $4 / 11 / 2009$ & & & -116 & -15.1 & UGTA Geochem DB - DRI \\
\hline & & & 4/9/2009 & 54.0 & 78.0 & & & UGTA Geochem DB - N-I \\
\hline & & & 4/9/2009 & 53.0 & 79.0 & & & UGTA Geochem DB - N-I \\
\hline & & & average N-I & 53.5 & 78.5 & & & \\
\hline & & & 4/9/2009 & 47.3 & 72.6 & -116 & -15.3 & UGTA Geochem DB - LLNL \\
\hline & & & average 2009 & 50.4 & 75.6 & -116 & -15.2 & \\
\hline & & & 6/10/2003 & 53.0 & 79.0 & & & UGTA Geochem DB - SNJV \\
\hline & & & $6 / 10 / 2003$ & 53.0 & 79.0 & & & UGTA Geochem DB - SNJV \\
\hline & & & average SNJV & 53.0 & 79.0 & & & \\
\hline & & & $6 / 10 / 2003$ & 51.7 & 75.4 & -117 & -15.0 & UGTA Geochem DB - LLNL \\
\hline & & & $6 / 10 / 2003$ & 49.5 & 79.1 & -115 & -14.9 & UGTA Geochem DB - DRI \\
\hline & & & $6 / 10 / 2003$ & & & -116 & -15.2 & UGTA Geochem DB - DRI \\
\hline & & & average DRI & & & -116 & -15.1 & \\
\hline & & & average 2003 & 51.4 & 77.8 & -116 & -15.0 & \\
\hline & & & $2 / 10 / 2000$ & 52.0 & 77.0 & & & UGTA Geochem DB - IT \\
\hline & & & $2 / 10 / 2000$ & 44.0 & 56.0 & -116 & -15.0 & UGTA Geochem DB - LLNL \\
\hline & & & $2 / 10 / 2000$ & & & -114 & -14.9 & UGTA Geochem DB - DRI \\
\hline & & & average 2000 & 48.0 & 66.5 & -115 & -15.0 & \\
\hline & & & average & 49.9 & 73.3 & -116 & -15.1 & \\
\hline \multirow[t]{3}{*}{ ER-EC-8 } & 370610 & 1163753 & $9 / 27 / 2010$ & 51.0 & 87.0 & & & UGTA Geochem DB - N-I \\
\hline & & & $9 / 27 / 2010$ & 51.0 & 87.0 & & & UGTA Geochem DB - N-I \\
\hline & & & average 2010 & 51.0 & 87.0 & & & \\
\hline
\end{tabular}


APPENDIX A. Chloride, Sulfate, and Isotopic Data (continued).

\begin{tabular}{|c|c|c|c|c|c|c|c|c|}
\hline Well Name & Latitude & Longitude & Date & $\begin{array}{c}\mathrm{Cl} \\
(\mathrm{mg} / \mathrm{L})\end{array}$ & $\begin{array}{c}\mathrm{SO}_{4} \\
(\mathrm{mg} / \mathrm{L})\end{array}$ & $\begin{array}{l}\delta^{2} H \\
(\%)\end{array}$ & $\begin{array}{c}\delta^{18} O \\
(\%)\end{array}$ & Reference \\
\hline \multirow[t]{10}{*}{ ER-EC-8 (cont.) } & & & $7 / 1 / 2003$ & 51.0 & 81.0 & & & UGTA Geochem DB - SNJV \\
\hline & & & 7/1/2003 & 51.0 & 80.0 & & & UGTA Geochem DB - SNJV \\
\hline & & & average SNJV & 51.0 & 80.5 & & & \\
\hline & & & $7 / 1 / 2003$ & 47.3 & 76.1 & -115 & -14.9 & UGTA Geochem DB - LLNL \\
\hline & & & $7 / 1 / 2003$ & 46.2 & 81.9 & -113 & -14.6 & UGTA Geochem DB - DRI \\
\hline & & & $7 / 1 / 2003$ & & & -114 & -14.8 & UGTA Geochem DB - DRI \\
\hline & & & average DRI & & & -114 & -14.7 & \\
\hline & & & average 2003 & 48.2 & 79.5 & -114 & -14.8 & \\
\hline & & & $7 / 12 / 2000$ & 57.6 & 94.0 & -116 & -14.8 & UGTA Geochem DB - LLNL \\
\hline & & & average & 52.3 & 86.8 & -115 & -14.8 & \\
\hline \multirow[t]{6}{*}{ ER-EC-11 } & 371151 & 1166294 & $5 / 18 / 2010$ & 42.0 & 70.0 & & & UGTA Geochem DB - N-I \\
\hline & & & $5 / 18 / 2010$ & 43.0 & 70.0 & & & UGTA Geochem DB - N-I \\
\hline & & & average N-I & 42.5 & 70.0 & & & \\
\hline & & & $5 / 18 / 2010$ & 44.5 & 69.9 & -117 & -15.3 & UGTA Geochem DB - LLNL \\
\hline & & & $5 / 18 / 2010$ & & & -115 & -15.2 & UGTA Geochem DB - DRI \\
\hline & & & average & 43.5 & 70.0 & -116 & -15.3 & \\
\hline \multirow[t]{3}{*}{ ER-EC-12 Upper } & 371024 & 1162931 & $11 / 27 / 2011$ & 16.0 & 35.0 & & & UGTA Geochem DB - N-I \\
\hline & & & 11/27/2011 & 15.0 & 35.0 & & & UGTA Geochem DB - N-I \\
\hline & & & average & 15.5 & 35.0 & & & \\
\hline \multirow{4}{*}{$\begin{array}{l}\text { ER-EC-13 } \\
\text { Intermediate }\end{array}$} & 371010 & 1163254 & $10 / 22 / 2010$ & 58.0 & 91.0 & & & UGTA Geochem DB - N-I \\
\hline & & & $10 / 22 / 2010$ & 59.0 & 89.0 & & & UGTA Geochem DB - N-I \\
\hline & & & $10 / 22 / 2010$ & 59.0 & 89.0 & & & UGTA Geochem DB - N-I \\
\hline & & & average & 58.7 & 89.7 & & & \\
\hline \multicolumn{9}{|l|}{ Kawich Range } \\
\hline \multirow{4}{*}{$\begin{array}{l}\text { Breen Creek } \\
\text { Marsh }\end{array}$} & 37.91757 & 116.4698 & $6 / 23 / 2000$ & 7.6 & & -100 & -14.0 & Mizell et al. (2008) \\
\hline & & & 12/29/1983 & & & -102 & -13.4 & UGTA Geochem DB - Sadler (1990) \\
\hline & & & 12/29/1983 & 7.2 & & & & UGTA Geochem DB - Raker (1987) \\
\hline & & & average & 7.4 & & -101 & -13.7 & \\
\hline
\end{tabular}


APPENDIX A. Chloride, Sulfate, and Isotopic Data (continued).

\begin{tabular}{|c|c|c|c|c|c|c|c|c|}
\hline Well Name & Latitude & Longitude & Date & $\begin{array}{c}\mathrm{Cl} \\
(\mathrm{mg} / \mathrm{L})\end{array}$ & $\begin{array}{c}\mathrm{SO}_{4} \\
(\mathrm{mg} / \mathrm{L})\end{array}$ & $\begin{array}{l}\delta^{2} H \\
(\% o)\end{array}$ & $\begin{array}{l}\delta^{18} O \\
(\%)\end{array}$ & Reference \\
\hline Tramp Spring & 37.88769 & 116.3691 & $\begin{array}{c}6 / 23 / 2011 \\
6 / 26 / 2000 \\
\text { average }\end{array}$ & $\begin{array}{l}9.6 \\
9.9 \\
9.8\end{array}$ & & -103 & -13.2 & $\begin{array}{l}\text { DRI } \\
\text { Mizell et al. (2008) }\end{array}$ \\
\hline Silverbow Spring & 37.86772 & 116.5073 & $\begin{array}{l}7 / 24 / 1996 \\
7 / 24 / 1996\end{array}$ & 22.6 & & -108 & -13.1 & $\begin{array}{l}\text { Mizell et al. (2008) } \\
\text { UGTA Geochem DB - LLNL }\end{array}$ \\
\hline Georges Water & 37.85976 & 116.3505 & $\begin{array}{c}6 / 15 / 2000 \\
4 / 29 / 1998 \\
1 / 11 / 1985 \\
1 / 11 / 1985 \\
\text { average }\end{array}$ & $\begin{array}{l}4.7 \\
4.0 \\
\\
\\
5.8 \\
4.8\end{array}$ & & $\begin{array}{l}-98 \\
-98 \\
-98 \\
-98\end{array}$ & $\begin{array}{l}-13.2 \\
-13.1 \\
-12.4 \\
-12.9\end{array}$ & $\begin{array}{l}\text { Mizell et al. (2008) } \\
\text { UGTA Geochem DB - LLNL } \\
\text { UGTA Geochem DB - Sadler (1990) } \\
\text { UGTA Geochem DB - Raker (1987) }\end{array}$ \\
\hline Corral Spring & 37.78421 & 116.3848 & $\begin{array}{c}5 / 18 / 2000 \\
1 / 6 / 1984 \\
1 / 6 / 1984 \\
\text { average }\end{array}$ & $\begin{array}{l}39.9 \\
\\
33.3 \\
36.6\end{array}$ & & $\begin{array}{l}-104 \\
-107 \\
-106\end{array}$ & $\begin{array}{l}-13.4 \\
-13.7 \\
-13.6\end{array}$ & $\begin{array}{l}\text { Mizell et al. (2008) } \\
\text { UGTA Geochem DB - Sadler (1990) } \\
\text { UGTA Geochem DB - Raker (1987) }\end{array}$ \\
\hline Sumner Spring & 37.77299 & 116.2912 & $\begin{array}{c}6 / 14 / 2000 \\
9 / 24 / 1996 \\
5 / 2 / 1996 \\
\text { average }\end{array}$ & $\begin{array}{l}24.3 \\
22.8 \\
23.6 \\
23.6\end{array}$ & & $\begin{array}{l}-101 \\
-107 \\
-103 \\
-104\end{array}$ & $\begin{array}{r}-13.2 \\
-13.34 \\
-12.5 \\
-13.0\end{array}$ & $\begin{array}{l}\text { Mizell et al. (2008) } \\
\text { UGTA Geochem DB - LLNL } \\
\text { UGTA Geochem DB - LLNL }\end{array}$ \\
\hline Cedar Spring & 37.75129 & 116.2739 & $\begin{array}{c}6 / 14 / 2000 \\
1 / 11 / 1985 \\
1 / 11 / 1985 \\
\text { average }\end{array}$ & $\begin{array}{r}23.9 \\
\\
23.8 \\
23.85\end{array}$ & & $\begin{array}{r}-98 \\
-101 \\
-100\end{array}$ & $\begin{array}{l}-12.5 \\
-12.4 \\
-12.5\end{array}$ & $\begin{array}{l}\text { Mizell et al. (2008) } \\
\text { UGTA Geochem DB - Sadler (1990) } \\
\text { UGTA Geochem DB - Raker (1987) }\end{array}$ \\
\hline Rose Spring & 37.74606 & 116.3331 & $\begin{array}{c}5 / 18 / 2000 \\
5 / 2 / 1996 \\
1 / 6 / 1984 \\
1 / 6 / 1984 \\
\text { average }\end{array}$ & $\begin{array}{l}24.2 \\
23.0 \\
\\
24.7 \\
24.0\end{array}$ & & $\begin{array}{l}-101 \\
-104 \\
-102 \\
-102\end{array}$ & $\begin{array}{l}-13.0 \\
-12.8 \\
-12.7 \\
-12.8\end{array}$ & $\begin{array}{l}\text { Mizell et al. (2008) } \\
\text { UGTA Geochem DB - LLNL } \\
\text { UGTA Geochem DB - Sadler (1990) } \\
\text { UGTA Geochem DB - Raker (1987) }\end{array}$ \\
\hline
\end{tabular}


APPENDIX A. Chloride, Sulfate, and Isotopic Data (continued).

\begin{tabular}{|c|c|c|c|c|c|c|c|c|}
\hline Well Name & Latitude & Longitude & Date & $\begin{array}{c}\mathrm{Cl} \\
(\mathrm{mg} / \mathrm{L})\end{array}$ & $\begin{array}{c}\mathrm{SO}_{4} \\
(\mathrm{mg} / \mathrm{L})\end{array}$ & $\begin{array}{l}\delta^{2} H \\
(\%)\end{array}$ & $\begin{array}{l}\delta^{18} O \\
(\%)\end{array}$ & Reference \\
\hline Black Spring & 38.1525 & 116.3847 & $\begin{array}{l}12 / 1 / 1984 \\
12 / 1 / 1984\end{array}$ & 10.9 & & -117 & -15.0 & $\begin{array}{l}\text { UGTA Geochem DB - Raker (1987) } \\
\text { UGTA Geochem DB - Sadler (1990) }\end{array}$ \\
\hline Edan Creek & 37.97 & 116.38 & $\begin{array}{l}1 / 11 / 1985 \\
1 / 11 / 1985\end{array}$ & 3.6 & & -99 & -12.7 & $\begin{array}{l}\text { UGTA Geochem DB - Raker (1987) } \\
\text { UGTA Geochem DB - Sadler (1990) }\end{array}$ \\
\hline Stinking Spring & 37.8943 & 116.5268 & $\begin{array}{c}6 / 24 / 2011 \\
12 / 29 / 1983 \\
12 / 29 / 1983 \\
\text { average }\end{array}$ & $\begin{array}{l}18.8 \\
17.1 \\
18.0\end{array}$ & & $\begin{array}{l}-100 \\
-106 \\
-103\end{array}$ & $\begin{array}{l}-12.6 \\
-13.3 \\
-12.9\end{array}$ & $\begin{array}{l}\text { DRI } \\
\text { UGTA Geochem DB - Raker (1987) } \\
\text { UGTA Geochem DB - Sadler (1990) }\end{array}$ \\
\hline Powder River & 37.7905 & 116.385 & $\begin{array}{l}1 / 6 / 1984 \\
1 / 6 / 1984\end{array}$ & 43.9 & & -100 & -12.1 & $\begin{array}{l}\text { UGTA Geochem DB - Raker (1987) } \\
\text { UGTA Geochem DB - Sadler (1990) }\end{array}$ \\
\hline Unnamed Spring & & & 6/23/2011 & 3.4 & & -99 & -13.3 & DRI \\
\hline $\begin{array}{l}\text { Gold Flat } \\
\text { Gold Flat \#2 Well }\end{array}$ & 37.42776 & 116.6107 & $\begin{array}{c}11 / 25 / 1996 \\
11 / 25 / 1996 \\
\text { average }\end{array}$ & $\begin{array}{l}5.8 \\
6.0 \\
5.9\end{array}$ & & -98 & -12.8 & $\begin{array}{l}\text { UGTA Geochem data base - HRCES } \\
\text { UGTA Geochem data base - LLNL }\end{array}$ \\
\hline S4 Well & 37.71161 & 116.43200 & $\begin{array}{l}12 / 5 / 2000 \\
1 / 27 / 1993 \\
\text { average }\end{array}$ & $\begin{array}{r}10.3 \\
9.5 \\
9.5\end{array}$ & & -117 & -15.1 & $\begin{array}{l}\text { Mizell et al. (2008) } \\
\text { Mizell et al. (2008) }\end{array}$ \\
\hline Cedar Pass Well & 37.74646 & 116.4841 & $\begin{array}{c}5 / 8 / 2002 \\
1 / 17 / 2002 \\
9 / 12 / 2000 \\
11 / 18 / 1999 \\
1 / 26 / 1999 \\
4 / 30 / 1996 \\
4 / 23 / 1987 \\
9 / 10 / 1980 \\
8 / 1 / 1978 \\
\text { average }\end{array}$ & $\begin{array}{l}16.0 \\
16.0 \\
15.2 \\
16.0 \\
16.0 \\
15.2 \\
14.7 \\
15.0 \\
14.0 \\
15.3\end{array}$ & & $\begin{array}{l}-105 \\
-111 \\
-110 \\
-109\end{array}$ & $\begin{array}{l}-14.1 \\
-14.0 \\
-13.9\end{array}$ & $\begin{array}{l}\text { UGTA Geochem data base - USAF } \\
\text { UGTA Geochem data base - USAF } \\
\text { Mizell et al. (2008) } \\
\text { UGTA Geochem data base - USAF } \\
\text { UGTA Geochem data base - USAF } \\
\text { UGTA Geochem data base - LLNL } \\
\text { UGTA Geochem data base - DRI } \\
\text { UGTA Geochem data base - USGS } \\
\text { UGTA Geochem data base - USAF }\end{array}$ \\
\hline
\end{tabular}


APPENDIX A. Chloride, Sulfate, and Isotopic Data (continued).

\begin{tabular}{|c|c|c|c|c|c|c|c|}
\hline Well Name & Latitude Longitude & Date & $\begin{array}{c}\mathrm{Cl} \\
(\mathrm{mg} / \mathrm{L})\end{array}$ & $\begin{array}{c}\mathrm{SO}_{4} \\
(\mathrm{mg} / \mathrm{L})\end{array}$ & $\begin{array}{l}\delta^{2} \mathbf{H} \\
(\% o)\end{array}$ & $\begin{array}{c}\delta^{18} O \\
(\%)\end{array}$ & Reference \\
\hline NNSS Springs & & 3/1/2011 & 29.4 & & -90 & -11.1 & DRI \\
\hline Cane Spring & & $2 / 28 / 2011$ & 4.2 & & -103 & -13.7 & DRI \\
\hline Captain Jack Spring & & $3 / 16 / 2011$ & 2.5 & & -89 & -11.7 & DRI \\
\hline Cottonwood Spring & & $6 / 22 / 2011$ & 0.6 & & -44 & 0.7 & DRI \\
\hline Gold Meadows Spring & & $2 / 23 / 2011$ & 9.9 & & -91 & -12.1 & DRI \\
\hline John's Spring & & $3 / 17 / 2011$ & 26.1 & & -97 & -10.8 & DRI \\
\hline Pavits Spring & & 3/1/2011 & NA & & -69 & -6.3 & DRI \\
\hline Reitmann Spring & & $2 / 28 / 2011$ & 7.3 & & -96 & -12.6 & DRI \\
\hline Tippipah Spring & & $2 / 23 / 2011$ & 11.7 & & -96 & -12.9 & DRI \\
\hline $\begin{array}{l}\text { Tub Spring } \\
\text { White Rock East Sprins }\end{array}$ & & $2 / 23 / 2011$ & 9.5 & & -96 & -12.7 & DRI \\
\hline
\end{tabular}


THIS PAGE INTENTIONALLY LEFT BLANK 
APPENDIX B. Emplacement Borehole Chemical and Isotopic Data.

\begin{tabular}{lccccccccc}
\hline $\begin{array}{l}\text { Sample } \\
\text { Name }\end{array}$ & $\begin{array}{c}\text { Sample } \\
\text { Date }\end{array}$ & $\mathbf{p H}$ & $\begin{array}{c}\mathbf{E C} \\
(\boldsymbol{\mu S} / \mathbf{c m})\end{array}$ & $\begin{array}{c}\mathrm{SiO}_{2} \\
(\mathbf{m g} / \mathbf{L})\end{array}$ & $\begin{array}{c}\mathbf{H C O}_{3} \\
(\mathbf{m g} / \mathbf{L})\end{array}$ & $\begin{array}{c}\mathbf{C O}_{3} \\
(\mathbf{m g} / \mathbf{L})\end{array}$ & $\begin{array}{c}\mathbf{C l} \\
(\mathbf{m g} / \mathbf{L})\end{array}$ & $\begin{array}{c}\mathbf{S O}_{4} \\
(\mathbf{m g} / \mathbf{L})\end{array}$ & $\begin{array}{c}\mathbf{N O}_{3}-\mathbf{N} \\
(\mathbf{m g} / \mathbf{L})\end{array}$ \\
\hline U-20bg & $6 / 27 / 2011$ & 8.39 & 274 & 56.6 & 125 & $<0.1$ & 6.6 & 14.8 & 0.57 \\
U-19bk & $6 / 27 / 2011$ & 7.97 & 171 & 68.3 & 82.2 & $<0.1$ & 4.8 & 8.4 & 0.60 \\
U-19bj & $6 / 28 / 2011$ & 8.27 & 365 & 55.0 & 148 & $<0.1$ & 15.7 & 27.5 & 2.1 \\
U-19bh & $6 / 28 / 2011$ & 8.25 & 428 & 52.6 & 154 & $<0.1$ & 8.6 & 22.8 & 1.7 \\
\hline
\end{tabular}

\begin{tabular}{lcccccccccc}
\hline $\begin{array}{l}\text { Sample } \\
\text { Name }\end{array}$ & $\begin{array}{c}\text { Sample } \\
\text { Date }\end{array}$ & $\begin{array}{c}\mathbf{N a} \\
(\mathbf{m g} / \mathbf{L})\end{array}$ & $\begin{array}{c}\mathbf{K} \\
\mathbf{( m g / L )}\end{array}$ & $\begin{array}{c}\mathbf{C a} \\
(\mathbf{m g} / \mathbf{L})\end{array}$ & $\begin{array}{c}\mathbf{M g} \\
(\mathbf{m g} / \mathbf{L})\end{array}$ & $\begin{array}{c}\mathbf{F} \\
(\mathbf{m g} / \mathbf{L})\end{array}$ & $\begin{array}{c}\mathbf{B r} \\
(\mathbf{m g} / \mathbf{L})\end{array}$ & $\begin{array}{c}\mathbf{T D S} \\
(\mathbf{m g} / \mathbf{L})\end{array}$ & $\begin{array}{c}\boldsymbol{\delta}^{\mathbf{2}} \mathbf{H} \\
\mathbf{( \% o})\end{array}$ & $\begin{array}{c}\boldsymbol{\delta}^{\mathbf{1 8}} \mathbf{O} \\
(\mathbf{\% o})\end{array}$ \\
\hline U-20bg & $6 / 27 / 2011$ & 53.9 & 5.24 & 5.39 & 0.07 & 3.00 & 0.04 & 212 & -107 & -13.7 \\
U-19bk & $6 / 27 / 2011$ & 34.1 & 3.06 & 2.51 & 0.08 & 0.66 & 0.81 & 163 & -115 & -15.0 \\
U-19bj & $6 / 28 / 2011$ & 54.4 & 10.5 & 19.0 & 0.63 & 1.10 & 0.02 & 263 & -101 & -13.5 \\
U-19bh & $6 / 28 / 2011$ & 96.4 & 3.89 & 0.74 & 0.04 & 19.6 & 0.20 & 294 & -102 & -13.5 \\
\hline
\end{tabular}


THIS PAGE INTENTIONALLY LEFT BLANK 


\title{
APPENDIX C. Review and Evaluation of Rainier Mesa Chloride Data for a Chloride Mass-Balance Infiltration Model
}

\author{
Ronald L. Hershey \\ Desert Research Institute \\ April 2, 2010
}

Los Alamos National Laboratory (LANL) is conducting a net infiltration study for Rainier Mesa; this study includes a chloride $(\mathrm{Cl})$ mass-balance infiltration model. LANL is using $\mathrm{Cl}$ data compiled by The Desert Research Institute (DRI) as part of a groundwater geochemical and isotopic study of the Rainier Mesa Corrective Action Unit (Hershey et al., 2008). At the request of LANL, DRI has evaluated the Cl data set from Hershey et al. (2008) for application to LANL's Cl mass balance infiltration model (Appendix). $309 \mathrm{Cl}$ measurements were grouped into different types, several questionable data were removed (Table 1), and summary statistics for each data type calculated (Table 2). The average of all $\mathrm{Cl}$ data was $12.5 \mathrm{mg} / \mathrm{L}$; however the data set has a large variance. Initially, averages for different types of data were calculated from all data for the type sample regardless of tunnel location, repeat sampling from the same location, or data quality. Averages of different types of data ranged from a low of $5.8 \mathrm{mg} / \mathrm{L}$ for water obtained by suction lysimeters within the Rainier Mesa tunnels to a high of $24.2 \mathrm{mg} / \mathrm{L}$ for ponded water behind gas-sealed doors and plugs.

Table 1. Questionable $\mathrm{Cl}$ data removed from data set (Cl in $\mathrm{mg} / \mathrm{L})$.

\begin{tabular}{llcl}
\hline \multicolumn{1}{c}{ Sample } & \multicolumn{1}{c}{ Type } & Cl & \multicolumn{1}{c}{ Reason } \\
\hline U12n.05 Bypass Drift & $\begin{array}{l}\text { Mass balance calculation } \\
\text { of interstitial fluid }\end{array}$ & 15.8 & estimated concentration \\
Lysimeter 7 & Suction lysimeter & 5 & Rainier Mesa surface sample \\
Lysimeter 9 & Suction Lysimeter & 32 & Rainier Mesa surface sample \\
U12n.12 Drift & leak & 12.4 & leak around lysimeter \\
U12e & Spring & 12 & unknown spring \\
U-12b SHAFT 07 NTS & Tunnel Shaft & 0 & Cl concentration reported as 0 mg/L \\
U12n main drift 3+00 & Unknown & 32 & no description of sample type \\
\hline
\end{tabular}


Table 2. $\quad$ Summary statistics for Rainier Mesa chloride data (mg/L).

\begin{tabular}{lcccc}
\hline Type of Sample & Average & Standard Deviation & Variance & Number \\
\hline All data & 12.5 & 9.4 & 87.9 & 309 \\
Seeps & 9.8 & 7.5 & 56.9 & 83 \\
Lysimeters & 5.8 & 3.3 & 10.9 & 31 \\
Pore waters & 21.0 & 13.0 & 168.4 & 43 \\
Plugs and doors & 24.2 & 11.9 & 141.2 & 28 \\
Portal drainage & 11.5 & 3.8 & 14.2 & 67 \\
Tunnel drill holes & 10.1 & 1.9 & 3.7 & 29 \\
Springs & 7.9 & 3.3 & 10.9 & 18 \\
Hagestad well* & 7.3 & & & 3 \\
\hline
\end{tabular}

* Standard deviation and variance not calculated because there is only one well sampling location considered

The quality of each data point, by type, was further evaluated. Seep data were separated into each specific tunnel and an average $\mathrm{Cl}$ concentration was calculated for any location where repeat sampling was conducted. In N Tunnel, one location, U-12n.03 Drift 0+50, was sampled 14 times between 1980 and 1986. As suggested by Russell (1987), some of these $\mathrm{Cl}$ data were impacted by underground testing (Figure 1). During a test, the pressure pulse squeezes higher $\mathrm{Cl}$ pore water out of the bedrock, which is not considered to be representative of recent infiltration, increasing the seep $\mathrm{Cl}$ concentration. The higher $\mathrm{Cl}$ content of pore water is shown in Table 1 . Cl concentrations affected by underground testing were removed from the data set to calculate the average seep data for $\mathrm{N}$ Tunnel. The same phenomenon was also seen in one seep in T Tunnel (Figure 2); these data were also removed from the average seep data for T Tunnel. Additionally, two other samples with very high $\mathrm{Cl}$ concentrations were removed from the seep data set (U12b STA 175 INB-2b, U12t Main Drift 17+22) because they were also likely impacted, although time series data were not available to verify testing impacts. Revised seep data averages for each tunnel are shown in Table 3.

Further evaluation of seep data showed several sampling locations where $\mathrm{Cl}$ concentrations were very low $(<2.0 \mathrm{mg} / \mathrm{L})$. If these low values are used in a $\mathrm{Cl}$ massbalance infiltration model for Rainier Mesa, the resulting estimates of net infiltration are large (e.g. 50 to 100 mm/y; Levitt and Kwicklis, 2010). Seep data from $\mathrm{N}$ and T tunnels were plotted spatially on tunnel maps, along with dates and number of samples at each location, to evaluate whether sample location or sample date could illuminate why these low concentrations were found (Figure 3 and Figure 4). Although there are several possibilities why these values are low, for example, poor analytical techniques or the water sampled was actually high-humidity tunnel condensation and not infiltration, there is insufficient evidence to exclude these data from further consideration. 


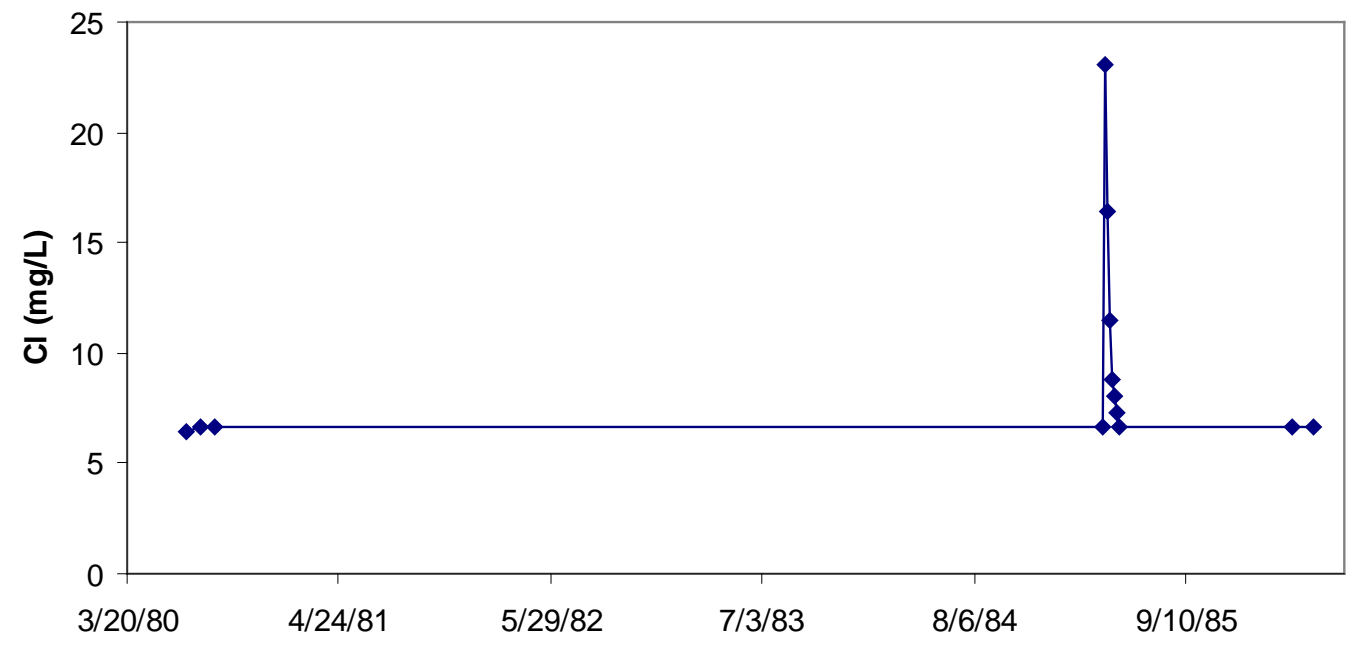

Figure 1. Seep U-12n.03 Drift 0+30 Cl samples. Samples impacted by underground nuclear testing have higher concentrations than samples before and after the test.

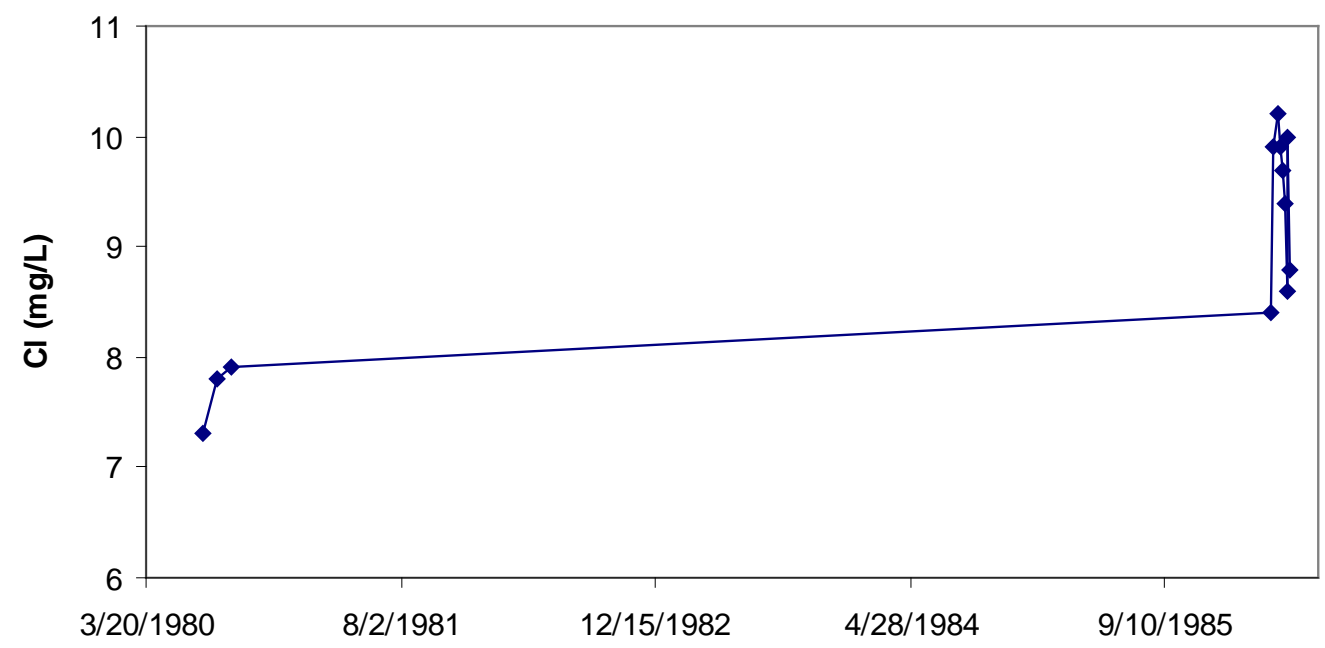

Figure 2. Seep U-12n.05 Bypass Drift Cl samples. Samples impacted by underground nuclear testing have higher concentrations than samples before and after the test. 
Table 3. Revised seep data for each tunnel and total for all seeps.

\begin{tabular}{lcccc}
\hline Type of Sample & Average & Standard Deviation & Variance & Number \\
\hline U-12b Tunnel & 8.2 & 3.5 & 12.6 & 3 \\
U-12e Tunnel & 8.2 & 3.5 & 12.5 & 22 \\
U-12n Tunnel & 8.4 & 3.7 & 13.7 & 8 \\
U-12t Tunnel & 7.8 & 4.6 & 21.4 & 9 \\
All Data & 8.1 & 3.7 & 13.6 & 42 \\
\hline
\end{tabular}

Portal Cl discharge data were compared to discharge measurements. Russell et al. (1993) showed that tunnel discharge is highly variable and that most of the discharge measurements were impacted by tunnel activities (Figures 5 and 6). Cl data are also variable and were likely impacted by tunnel activities. 


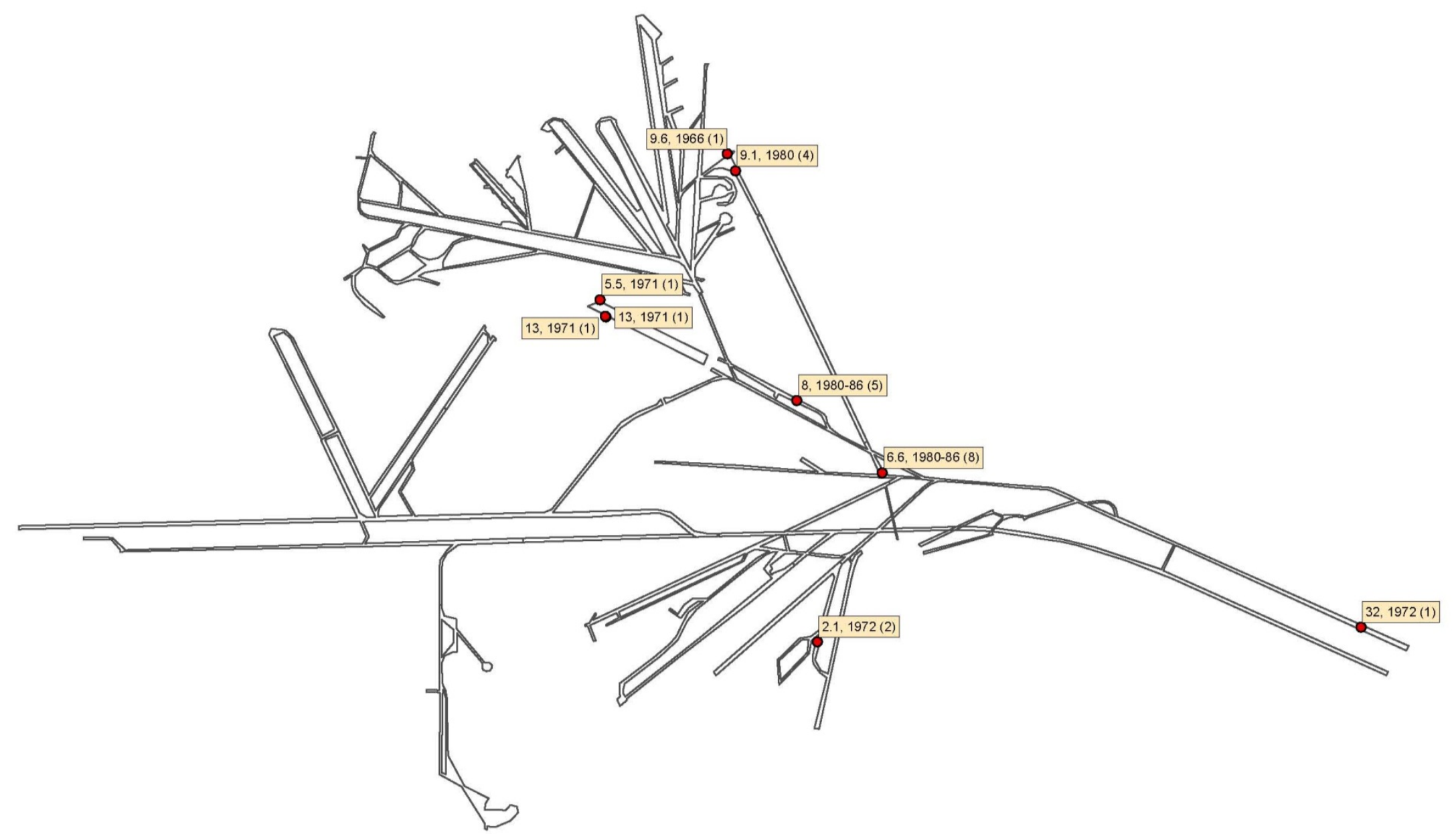

Figure 3. Seep Cl data shown on U-12n Tunnel map. Red dots indicate sampling location, first number is the average Cl concentration (mg/L), second is the year the samples were collected, and the third number in parentheses is the number of samples used to compute the average. 


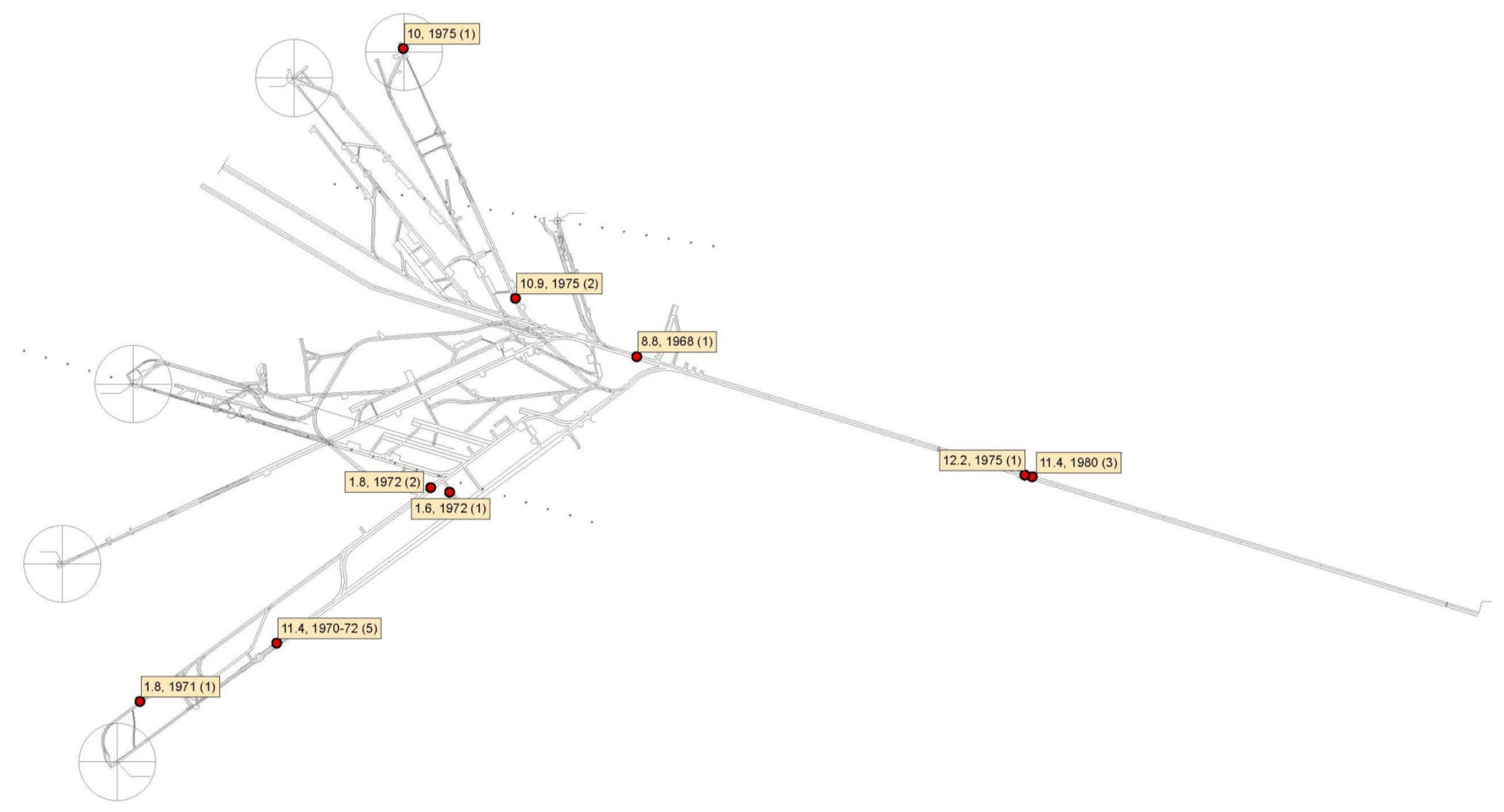

Figure 4. Seep Cl data shown on U-12t Tunnel map. Red dots indicate sampling location, first number is the average $\mathrm{Cl}$ concentration (mg/L), second is the year the samples were collected, and the third number in parentheses is the number of samples used to compute the average. 


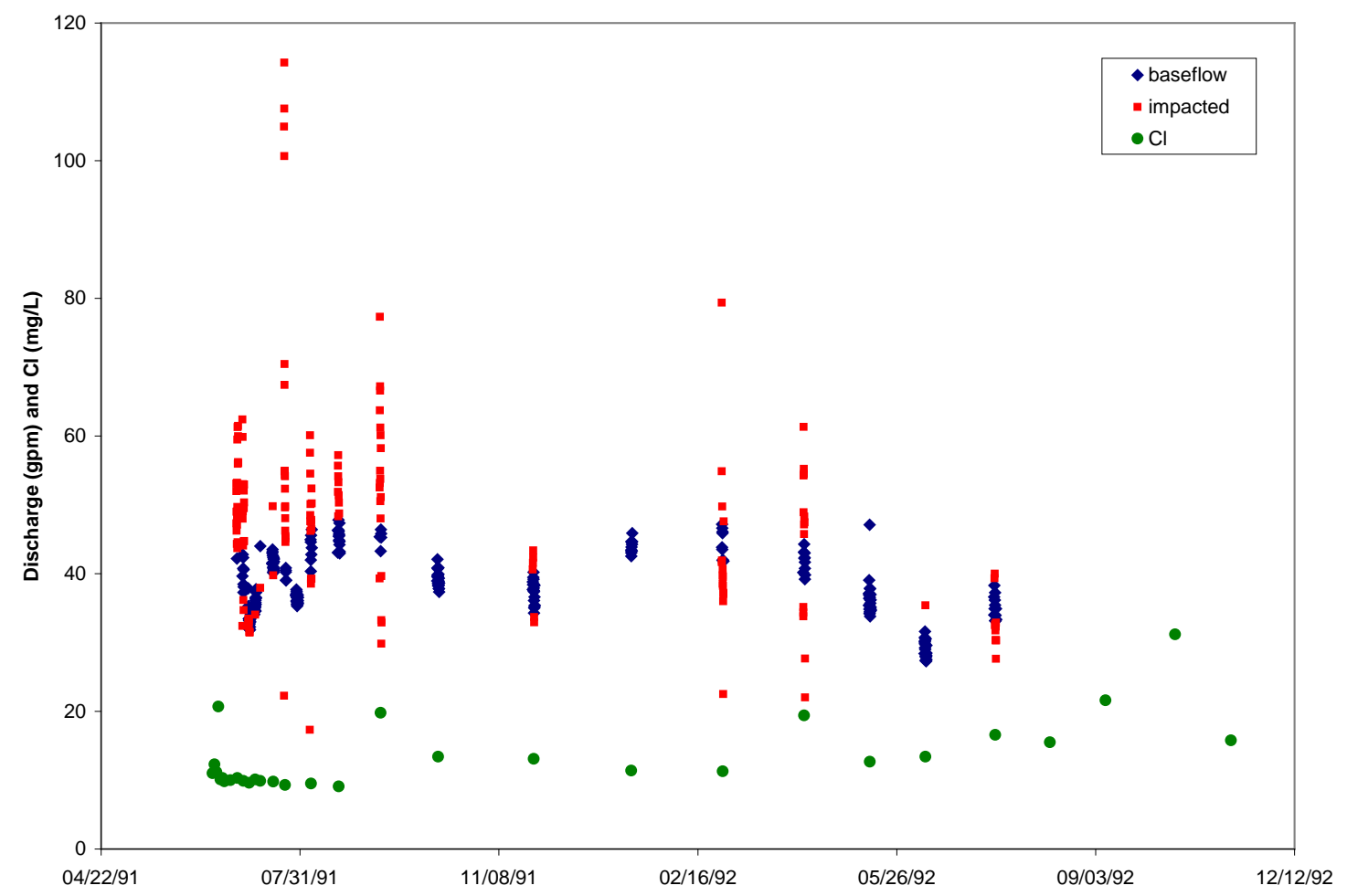

Figure 5. U-12n Tunnel portal discharge and Cl data.

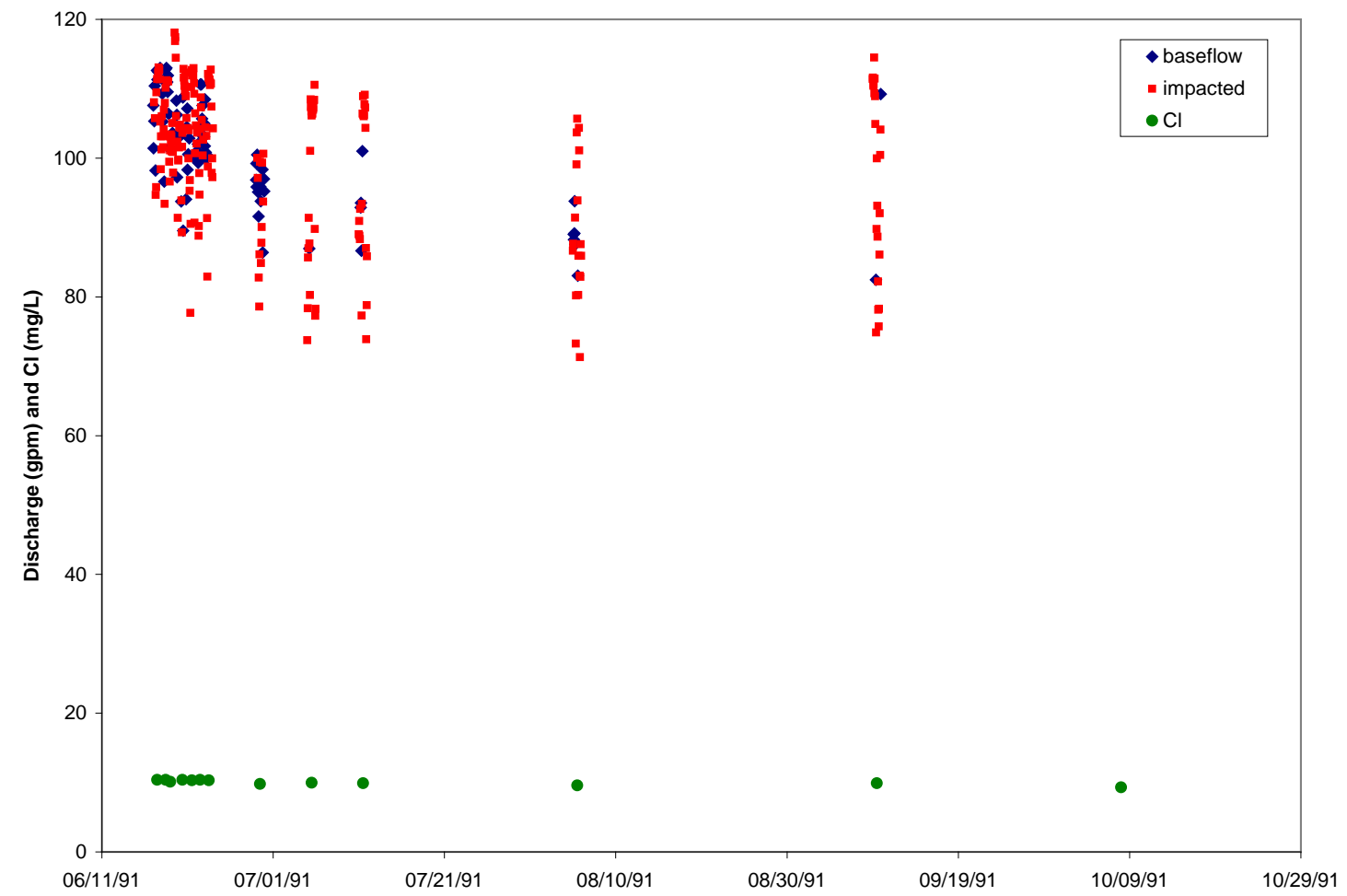

Figure 6. U-12t Tunnel portal discharge and Cl data. 
Assuming that seep samples collected from free flowing fractures are most representative of Rainier Mesa infiltration, the other data types were evaluated against the seep data using the T-Test, which estimates whether the mean of one data set is statistically different from the mean of another set. Resulting $\mathrm{P}$ values from a T-Test are used to indicate the strength of evidence that one set is statistically different from another (Table 4) (http://www.stat.ualberta.ca/ hooper/teaching/misc/Pvalue.pdf). For this analysis, the null hypothesis was that the means of the different types of data were equal to the mean of the seep data $\left(\mathrm{H}_{0}=\bar{x}_{\text {seeps }}-\bar{x}_{\text {other }}=0\right)$.

Table 4. T-Test P-value ranges for determining the strength of evidence that one data set is statistically different from another.

\begin{tabular}{ll}
\hline $\mathrm{P}>0.10$ & $\begin{array}{l}\text { No evidence against the null hypothesis. The data appear to be consistent with the } \\
\text { null hypothesis. }\end{array}$ \\
$0.05<\mathrm{P}<0.10$ & $\begin{array}{l}\text { Weak evidence against the null hypothesis in favor of the alternative. } \\
0.01<\mathrm{P}<0.05\end{array}$ \\
$\begin{array}{l}\text { Moderate evidence against the null hypothesis in favor of the alternative. } \\
\text { P }<001<\mathrm{P}<0.01\end{array}$ & $\begin{array}{l}\text { Strong evidence against the null hypothesis in favor of the alternative. } \\
\text { Very strong evidence against the null hypothesis in favor of the alternative. }\end{array}$ \\
\hline
\end{tabular}

Table 5. T-Test Results comparing seep data to other types of data. Null hypothesis was $\mathrm{H}_{0}=\bar{X}_{\text {seeps }}-\bar{x}_{\text {other }}=0$ and $\alpha=0.05$.

\begin{tabular}{lcccc}
\hline \multicolumn{1}{c}{ Type of Sample } & $\begin{array}{c}\text { Degrees of } \\
\text { Freedom }\end{array}$ & T Statistic & P Value one tail & P Value two tail \\
\hline Lysimeters & 10 & 1.22 & 0.13 & 0.25 \\
Pore waters & 4 & -3.83 & 0.009 & 0.019 \\
Plugs and doors & 3 & -3.3 & 0.023 & 0.046 \\
& 24 & & & \\
Portal drainage & 58 & -2.69 & 0.006 & 0.012 \\
Tunnel drill holes & 2 & -2.22 & 0.015 & 0.030 \\
Springs & 3 & -2.27 & 0.421 & 0.841 \\
Hagestad well & & 0.589 & 0.299 & 0.597 \\
\hline
\end{tabular}


From T-Test analysis, lysimeters, springs, and the Hagestad well data are statistically the same as seep data; while the gas-seal plugs and doors data and tunnel drillhole data are moderately dissimilar; and pore water and portal drainage data are very dissimilar (Table 5). For this analysis, the average for each sample type was used, except for the Hagestad well where three $\mathrm{Cl}$ concentrations were compared to the seep data so that a T-Test could be conducted (no results for a T-Test where one data set only has one mean).

\section{Conclusions}

Seep data are considered to be the most representative data set for Rainier Mesa infiltration. Some very low $\mathrm{Cl}$ concentration seep samples may not be representative of infiltration and could be the result of poor analytical techniques or sampling of highhumidity tunnel condensation, but there is insufficient evidence to exclude these data from further consideration. Cl data for a Rainier Mesa chloride mass-balance infiltration model should be limited to seeps, springs, and the Hagestad well data based upon this data review and evaluation. Ideally, instead of using the individual data points, the average and standard deviation of the combined seeps, springs, and Hagestad well data should be used to capture the uncertainty in the Cl data set, which are:

$$
\begin{aligned}
& \text { Mean }=8.1 \\
& \text { Standard Deviation }=3.7 \\
& \text { Variance }=13.5 \\
& \text { Number }=46
\end{aligned}
$$

\section{References}

Hershey, R.L., J.B. Paces, M.J. Singleton, E.M. Kwicklis, D.L. Decker, W.M. Fryer, and S. Earman, 2008. Geochemical and Isotopic Evaluation of Groundwater Movement in Corrective Action Unit 99: Rainier Mesa and Shoshone Mountain, Nevada Test Site. Desert Research Institute Publication No. 45229.

Levitt, D. and E. Kwicklis, 2010. Rainier Mesa Infiltration. Presentation to Rainier Mesa Sub-CAU Model Preemptive Review Committee, January 21, 2010. Las Vegas, Nevada.

Russell, C.E., 1987. Hydrogeologic Investigation of Flow in Fractured Tuffs, Rainier Mesa, Nevada Test Site. University of Nevada, Las Vegas Master Thesis, 154 p.

Russell, C.E., L. Gillespie, and D. Gillespie, 1993. Geochemical and Hydrologic Characterization of the Effluent Draining from U12e, U12n, and U12t tunnels, Area 12, Nevada Test Site. Desert Research Institute Publication No. 45105. 


\section{APPENDIX for Report: Review and Evaluation of Rainier Mesa Chloride Data for a Chloride Mass-Balance Infiltration}

Model. Chloride data recommended for use in a chloride mass balance infiltration model.

\begin{tabular}{|c|c|c|c|c|c|}
\hline $\begin{array}{c}\text { Sample Location } \\
\text { Name } \\
\end{array}$ & Type of Sample & $\begin{array}{c}\text { Date Sample } \\
\text { was Collected }\end{array}$ & $\begin{array}{c}\mathrm{Cl} \\
\mathrm{mg} / \mathrm{l}\end{array}$ & Comment & Citation \\
\hline \multicolumn{6}{|l|}{ SEEPS } \\
\hline U12b STA. 14+65 & seep - CLEAR & 6/6/1958 & 5 & seep & $\begin{array}{l}\text { Perfect, D.L., C.C. Faunt, W.C. Steinkampf, and A. K. Turner. } 1994 . \\
\text { Hydrochemical Data Base for the Death Valley Region, California } \\
\text { and Nevada. USGS Open-'File Report 94-305 and Diment et al, } \\
\text { 1959. Geological Survey Investigations in the U12b.03 and U12b }\end{array}$ \\
\hline U12B.03 STA 3+70 & $\begin{array}{l}\text { Seep - CLEAR; SEEP FROM } \\
\text { FRACTURES IN TUNNEL } \\
\text { CEILING }\end{array}$ & 8/22/1958 & 7.5 & $\begin{array}{l}\text { Seep Water from } \\
\text { Fracture in back }\end{array}$ & $\begin{array}{l}\text { Perfect, D.L., C.C. Faunt, W.C. Steinkampf, and A. K. Turner. } 1994 . \\
\text { Hydrochemical Data Base for the Death Valley Region, California } \\
\text { and Nevada. USGS Open-'File Report 94-305 and Diment et al, } \\
\text { 1959. Geological Survey Investigations in the U12b.03 and U12b }\end{array}$ \\
\hline U12 B.04 ST 3+26 & $\begin{array}{l}\text { Back Seep - CLEAR; } \\
\text { SAMPLE VOLUME TOO } \\
\text { SMALL TO RUN } \\
\text { ADDITIONAL TESTS }\end{array}$ & 10/1/1958 & 12 & Back, seep & $\begin{array}{l}\text { Perfect, D.L., C.C. Faunt, W.C. Steinkampf, and A. K. Turner. } 1994 . \\
\text { Hydrochemical Data Base for the Death Valley Region, California } \\
\text { and Nevada. USGS Open-'File Report 94-305 and Diment et al, } \\
\text { 1959. Geological Survey Investigations in the U12b.03 and U12b }\end{array}$ \\
\hline U12e STA.9+71 & $\begin{array}{l}\text { Spring - TURBID; MINE } \\
\text { WATER FROM OPEN } \\
\text { JOINT IN TUNNEL }\end{array}$ & 7/21/1958 & 16 & Right Wall, joint & $\begin{array}{l}\text { Perfect, D.L., C.C. Faunt, W.C. Steinkampf, and A. K. Turner. } 1994 . \\
\text { Hydrochemical Data Base for the Death Valley Region, California } \\
\text { and Nevada. USGS Open-'File Report 94-305. and Clebsch, A. } \\
\text { 1960. Analyses of Groundwater From Rainier Mesa, Nevada Test } \\
\text { Site }\end{array}$ \\
\hline $\begin{array}{l}\text { U12e Main Drift } \\
\text { 27+86 }\end{array}$ & $\begin{array}{l}\text { Tunnel - TV, ZEOLITIZED } \\
\text { TUFF IN TUNNEL BED 2C } \\
\text { OR 2D IN INDIAN TRAIL } \\
\text { FM }\end{array}$ & 8/3/1972 & 6 & seep & $\begin{array}{l}\text { Perfect, D.L., C.C. Faunt, W.C. Steinkampf, and A. K. Turner. } 1994 . \\
\text { Hydrochemical Data Base for the Death Valley Region, California } \\
\text { and Nevada. USGS Open-'File Report 94-305. }\end{array}$ \\
\hline U12e Main 29+35 & $\begin{array}{l}\text { seep back, fracture from } \\
\text { lagging - CLEAR; DRIPS } \\
\text { FROM LAGGING NR RT } \\
\text { SPRING LINE; FRACTURE } \\
\text { IN TUNNEL ROOF }\end{array}$ & $11 / 22 / 1959$ & 6 & seep & $\begin{array}{l}\text { Perfect, D.L., C.C. Faunt, W.C. Steinkampf, and A. K. Turner. } \\
\text { 1994. Hydrochemical Data Base for the Death Valley Region, } \\
\text { California and Nevada. USGS Open-'File Report 94-305. }\end{array}$ \\
\hline
\end{tabular}


APPENDIX for Report: Review and Evaluation of Rainier Mesa Chloride Data for a Chloride Mass-Balance Infiltration Model. Chloride data recommended for use in a chloride mass balance infiltration model (continued).

\begin{tabular}{|c|c|c|c|c|c|}
\hline $\begin{array}{c}\text { Sample Location } \\
\text { Name } \\
\end{array}$ & Type of Sample & $\begin{array}{c}\text { Date Sample } \\
\text { was Collected }\end{array}$ & $\begin{array}{c}\mathrm{Cl} \\
\mathrm{mg} / \mathrm{l}\end{array}$ & Comment & Citation \\
\hline U12e Main 29+36 & $\begin{array}{l}\text { Tunnel DRIP - Drip IS } \\
\text { FROM LAGGING AND } \\
\text { AIR PIPE, FROM TUNNEL } \\
\text { ROOF }\end{array}$ & $1 / 22 / 1959$ & 10 & Back; from Lagging & $\begin{array}{l}\text { Perfect, D.L., C.C. Faunt, W.C. Steinkampf, and A. K. Turner. } \\
\text { 1994. Hydrochemical Data Base for the Death Valley Region, } \\
\text { California and Nevada. USGS Open-'File Report 94-305. }\end{array}$ \\
\hline U12e Main 35+75 & $\begin{array}{l}\text { fracture - TURBID; FROM } \\
\text { FRACTURE IN TUNNEL } \\
\text { ROOF }\end{array}$ & $1 / 29 / 1959$ & 8 & seep & $\begin{array}{l}\text { Perfect, D.L., C.C. Faunt, W.C. Steinkampf, and A. K. Turner. } \\
\text { 1994. Hydrochemical Data Base for the Death Valley Region, } \\
\text { California and Nevada. USGS Open-'File Report 94-305. }\end{array}$ \\
\hline U12e Main 40+75 & Seep, face, Fault zone & 6/1/1959 & 8 & $\begin{array}{l}\text { Seep, face, Fault } \\
\text { zone }\end{array}$ & $\begin{array}{l}\text { Clebsch, A. 1960. Analyses of Groundwater From Rainier Mesa, } \\
\text { Nevada Test Site, Nye County, Nevada. Trace Elements } \\
\text { Investigations Report 763. } 1960 .\end{array}$ \\
\hline U12e 40+82 & $\begin{array}{l}\text { seep, cloudy, vertical fracture } \\
\text { in right wall, } 4 \mathrm{ft} \text { above floor }\end{array}$ & 11/29/1959 & 4 & $\begin{array}{l}\text { seep, vertical fracture } \\
\text { in right wall, } 4 \mathrm{ft} \\
\text { above floor }\end{array}$ & $\begin{array}{l}\text { Perfect, D.L., C.C. Faunt, W.C. Steinkampf, and A. K. Turner. } \\
\text { 1994. Hydrochemical Data Base for the Death Valley Region, } \\
\text { California and Nevada. USGS Open-'File Report 94-305. }\end{array}$ \\
\hline U12e Main 48+05 & $\begin{array}{l}\text { Seep, Back, Joint - } \\
\text { COLORED WHITISH; } \\
\text { MAY BE } \\
\text { CONTAMINATED BY } \\
\text { DIESEL EXHAUST }\end{array}$ & 6/25/1959 & 12 & seep & $\begin{array}{l}\text { Perfect, D.L., C.C. Faunt, W.C. Steinkampf, and A. K. Turner. } \\
\text { 1994. Hydrochemical Data Base for the Death Valley Region, } \\
\text { California and Nevada. USGS Open-'File Report 94-305. }\end{array}$ \\
\hline U12e 54+32 & $\begin{array}{l}\text { Seep, back, } 4 \mathrm{ft} \text { left of center; } \\
\text { fracture - CLEAR; DRIPS } \\
\text { FROM TUNNEL } \\
\text { FRACTURE }\end{array}$ & 7/18/1959 & 12 & seep & $\begin{array}{l}\text { Perfect, D.L., C.C. Faunt, W.C. Steinkampf, and A. K. Turner. } \\
\text { 1994. Hydrochemical Data Base for the Death Valley Region, } \\
\text { California and Nevada. USGS Open-'File Report 94-305. }\end{array}$ \\
\hline U12e.01 4+35 & $\begin{array}{l}\text { Seep, right wall - } \\
\text { TURBIDITY COULD NOT } \\
\text { BE REMOVED }\end{array}$ & 9/30/1959 & 3 & seep & $\begin{array}{l}\text { Perfect, D.L., C.C. Faunt, W.C. Steinkampf, and A. K. Turner. } \\
\text { 1994. Hydrochemical Data Base for the Death Valley Region, } \\
\text { California and Nevada. USGS Open-'File Report 94-305. }\end{array}$ \\
\hline
\end{tabular}


APPENDIX for Report: Review and Evaluation of Rainier Mesa Chloride Data for a Chloride Mass-Balance Infiltration Model. Chloride data recommended for use in a chloride mass balance infiltration model (continued).

\begin{tabular}{|c|c|c|c|c|c|}
\hline $\begin{array}{c}\text { Sample Location } \\
\text { Name } \\
\end{array}$ & Type of Sample & $\begin{array}{c}\text { Date Sample } \\
\text { was Collected }\end{array}$ & $\begin{array}{c}\mathrm{Cl} \\
\mathrm{mg} / \mathrm{l}\end{array}$ & Comment & Citation \\
\hline U12E.02 STA $6+10$ & $\begin{array}{l}\text { Seep, Left Wall, } 5 \mathrm{ft} \text { above } \\
\text { floor; fracture - CLEAR; } \\
\text { FROM FRACTURE IN } \\
\text { TUNNEL WALL }\end{array}$ & 10/11/1958 & 9.5 & $\begin{array}{l}\text { seep - Left Wall, } 5 \mathrm{ft} \\
\text { above floor; fracture }\end{array}$ & $\begin{array}{l}\text { Perfect, D.L., C.C. Faunt, W.C. Steinkampf, and A. K. Turner. } \\
\text { 1994. Hydrochemical Data Base for the Death Valley Region, } \\
\text { California and Nevada. USGS Open-'File Report } 94-305 \text { and } \\
\text { Clebsch, A. } 1960 \text {. Analyses of Groundwater From Rainier Mesa, } \\
\text { Nevada Test Sit }\end{array}$ \\
\hline U12e.02X 1+91 & $\begin{array}{l}\text { Seep - right wall - } \\
\text { COLORED; VERY SLOW } \\
\text { TUNNEL SEEP, VERY } \\
\text { SMALL SAMPLE }\end{array}$ & 1/29/1959 & 10 & $\begin{array}{l}\text { right wall - seep - } \\
\text { Sample is } \\
\text { contaminated with } \\
\text { rad }\end{array}$ & $\begin{array}{l}\text { Perfect, D.L., C.C. Faunt, W.C. Steinkampf, and A. K. Turner. } \\
\text { 1994. Hydrochemical Data Base for the Death Valley Region, } \\
\text { California and Nevada. USGS Open-'File Report 94-305. }\end{array}$ \\
\hline U12e.03 4+15 & $\begin{array}{l}\text { Seep Back. Left side - VERY } \\
\text { TURBID, ORANGE-PINK; } \\
\text { LOC 415' FROM } \\
\text { ENTRANCE OF } \\
\text { PERSONNEL BRANCH }\end{array}$ & $5 / 20 / 1959$ & 10 & $\begin{array}{l}\text { Seep, Back, left side } \\
\text { - Filtered in field } \\
\text { through } 41-\mathrm{H} \text { ashless } \\
\text { paper }\end{array}$ & $\begin{array}{l}\text { Perfect, D.L., C.C. Faunt, W.C. Steinkampf, and A. K. Turner. } \\
\text { 1994. Hydrochemical Data Base for the Death Valley Region, } \\
\text { California and Nevada. USGS Open-'File Report 94-305. }\end{array}$ \\
\hline U12e.03 9+20, & $\begin{array}{l}\text { Tunnel - CLOUDY, ALL } \\
\text { SED NOT REMOVED BY } \\
\text { FILTERING; FROM JOINT } \\
\text { IN BACK OF TUNNEL }\end{array}$ & $12 / 14 / 1959$ & 2 & seep & $\begin{array}{l}\text { Perfect, D.L., C.C. Faunt, W.C. Steinkampf, and A. K. Turner. } \\
\text { 1994. Hydrochemical Data Base for the Death Valley Region, } \\
\text { California and Nevada. USGS Open-'File Report 94-305. }\end{array}$ \\
\hline U12e.03 10+25P & $\begin{array}{l}\text { tunnel seep - SLI BRN } \\
\text { SEDIMENT; }\end{array}$ & $12 / 3 / 1959$ & 8 & seep & $\begin{array}{l}\text { Perfect, D.L., C.C. Faunt, W.C. Steinkampf, and A. K. Turner. } \\
\text { 1994. Hydrochemical Data Base for the Death Valley Region, } \\
\text { California and Nevada. USGS Open-'File Report 94-305. }\end{array}$ \\
\hline $\begin{array}{l}\text { U12e.03 10+25.5 } \\
\text { PERSONNEL BR }\end{array}$ & $\begin{array}{l}\text { Seep, Right wall, fracture } 4 \\
\text { inches wide, breccia filled - } \\
\text { TURBID, PINK-GREY; }\end{array}$ & 5/27/1959 & 9 & seep & $\begin{array}{l}\text { Perfect, D.L., C.C. Faunt, W.C. Steinkampf, and A. K. Turner. } \\
\text { 1994. Hydrochemical Data Base for the Death Valley Region, } \\
\text { California and Nevada. USGS Open-'File Report 94-305. }\end{array}$ \\
\hline
\end{tabular}


APPENDIX for Report: Review and Evaluation of Rainier Mesa Chloride Data for a Chloride Mass-Balance Infiltration Model. Chloride data recommended for use in a chloride mass balance infiltration model (continued).

\begin{tabular}{|c|c|c|c|c|c|}
\hline $\begin{array}{l}\text { Sample Location } \\
\text { Name }\end{array}$ & Type of Sample & $\begin{array}{c}\text { Date Sample } \\
\text { was Collected }\end{array}$ & $\begin{array}{c}\mathrm{Cl} \\
\mathrm{mg} / \mathrm{l}\end{array}$ & Comment & Citation \\
\hline $\begin{array}{l}\text { U12e.03 10+25.5 } \\
\text { PERSONNEL BR }\end{array}$ & $\begin{array}{l}\text { Tunnel Frac - FROM } \\
\text { BRECCIA FILLED } \\
\text { FRACTURE IN TUNNEL; } \\
\text { TURBID PINKISH GREY } \\
\text { W SEDIMENT }\end{array}$ & 6/2/1959 & 9 & seep & $\begin{array}{l}\text { Perfect, D.L., C.C. Faunt, W.C. Steinkampf, and A. K. Turner. } \\
\text { 1994. Hydrochemical Data Base for the Death Valley Region, } \\
\text { California and Nevada. USGS Open-'File Report 94-305. }\end{array}$ \\
\hline $\begin{array}{l}\text { U12e.03 11+86 - } \\
\text { Vertical Drillhole }\end{array}$ & $\begin{array}{l}\text { Seep, vertical drillhole - DK } \\
\text { YELLOW-ORANGE; WL } \\
305 \text { ' BELOW FLOOR OF } \\
\text { TUNNEL }\end{array}$ & 7/10/1959 & 12 & well & $\begin{array}{l}\text { Perfect, D.L., C.C. Faunt, W.C. Steinkampf, and A. K. Turner. } \\
\text { 1994. Hydrochemical Data Base for the Death Valley Region, } \\
\text { California and Nevada. USGS Open-'File Report 94-305. }\end{array}$ \\
\hline U12e.04 16+68 & $\begin{array}{l}\text { Seep Back - CLEAR W RED } \\
\text { SEDIMENT }\end{array}$ & 6/2/1959 & 3.5 & seep & $\begin{array}{l}\text { Perfect, D.L., C.C. Faunt, W.C. Steinkampf, and A. K. Turner. } \\
\text { 1994. Hydrochemical Data Base for the Death Valley Region, } \\
\text { California and Nevada. USGS Open-'File Report 94-305. }\end{array}$ \\
\hline U12e.04 PERS 3+02 & Tunnel CLEAR & 1/7/1960 & 6 & seep & $\begin{array}{l}\text { Perfect, D.L., C.C. Faunt, W.C. Steinkampf, and A. K. Turner. } \\
\text { 1994. Hydrochemical Data Base for the Death Valley Region, } \\
\text { California and Nevada. USGS Open-'File Report 94-305. }\end{array}$ \\
\hline U12e.04 PERS 3+02 & Tunnel - CLEAR & $7 / 7 / 1960$ & 6 & seep & $\begin{array}{l}\text { Perfect, D.L., C.C. Faunt, W.C. Steinkampf, and A. K. Turner. } \\
\text { 1994. Hydrochemical Data Base for the Death Valley Region, } \\
\text { California and Nevada. USGS Open-'File Report 94-305. }\end{array}$ \\
\hline U12e.05 1+84 & $\begin{array}{l}\text { Seep - MILKY, FROM } \\
\text { FRACTURE SYSTEM IN } \\
\text { TUNNEL }\end{array}$ & 9/12/1958 & 10 & Fracture System & $\begin{array}{l}\text { Perfect, D.L., C.C. Faunt, W.C. Steinkampf, and A. K. Turner. } \\
\text { 1994. Hydrochemical Data Base for the Death Valley Region, } \\
\text { California and Nevada. USGS Open-'File Report 94-305. and } \\
\text { Clebsch, A. 1960. Analyses of Groundwater From Rainier Mesa, } \\
\text { Nevada Test Site }\end{array}$ \\
\hline U12e.07 4+15 & $\begin{array}{l}\text { Seep in Tunnel - SAMPLE } \\
\text { CLEAR }\end{array}$ & 3/18/1960 & 4 & seep & $\begin{array}{l}\text { Perfect, D.L., C.C. Faunt, W.C. Steinkampf, and A. K. Turner. } \\
\text { 1994. Hydrochemical Data Base for the Death Valley Region, } \\
\text { California and Nevada. USGS Open-'File Report 94-305. }\end{array}$ \\
\hline
\end{tabular}


APPENDIX for Report: Review and Evaluation of Rainier Mesa Chloride Data for a Chloride Mass-Balance Infiltration Model. Chloride data recommended for use in a chloride mass balance infiltration model (continued).

\begin{tabular}{|c|c|c|c|c|c|}
\hline $\begin{array}{c}\text { Sample Location } \\
\text { Name } \\
\end{array}$ & Type of Sample & $\begin{array}{c}\text { Date Sample } \\
\text { was Collected }\end{array}$ & $\begin{array}{c}\mathrm{Cl} \\
\mathrm{mg} / \mathrm{l}\end{array}$ & Comment & Citation \\
\hline U12e.18 work point & TUNNEL WALL & 2/10/1975 & 10.6 & seep & $\begin{array}{l}\text { Perfect, D.L., C.C. Faunt, W.C. Steinkampf, and A. K. Turner. } \\
\text { 1994. Hydrochemical Data Base for the Death Valley Region, } \\
\text { California and Nevada. USGS Open-'File Report 94-305. }\end{array}$ \\
\hline U12n.03 Drift 0+50 & seep & 4/3/1980 & 6.5 & $\begin{array}{l}\text { Seep analyses taken in } \\
\text { support of lysimeter } \\
\text { study. Not all } \\
\text { lysimeter data was used }\end{array}$ & $\begin{array}{l}\text { Jacobson, R.L., M.S. Henne, and J.W. Hess. 1986. A } \\
\text { reconnaissance investigation of hydrogeochemistry and } \\
\text { hydrology of Rainier Mesa. Desert Research Institute } \\
\text { Publication } 45046\end{array}$ \\
\hline U12n.03 Drift 0+50 & seep & 7/9/1980 & 6.4 & $\begin{array}{l}\text { Seep analyses taken in } \\
\text { support of lysimeter } \\
\text { study. Not all } \\
\text { lysimeter data was used }\end{array}$ & $\begin{array}{l}\text { Jacobson, R.L., M.S. Henne, and J.W. Hess. 1986. A } \\
\text { reconnaissance investigation of hydrogeochemistry and } \\
\text { hydrology of Rainier Mesa. Desert Research Institute } \\
\text { Publication } 45046\end{array}$ \\
\hline U12n.03 Drift 0+50 & seep & 8/6/1980 & 6.6 & $\begin{array}{l}\text { Seep analyses taken in } \\
\text { support of lysimeter } \\
\text { study. Not all } \\
\text { lysimeter data was used }\end{array}$ & $\begin{array}{l}\text { Jacobson, R.L., M.S. Henne, and J.W. Hess. 1986. A } \\
\text { reconnaissance investigation of hydrogeochemistry and } \\
\text { hydrology of Rainier Mesa. Desert Research Institute } \\
\text { Publication } 45046\end{array}$ \\
\hline U12n.03 Drift 0+50 & seep & 9/3/1980 & 6.6 & $\begin{array}{l}\text { Seep analyses taken in } \\
\text { support of lysimeter } \\
\text { study. Not all } \\
\text { lysimeter data was used }\end{array}$ & $\begin{array}{l}\text { Jacobson, R.L., M.S. Henne, and J.W. Hess. 1986. A } \\
\text { reconnaissance investigation of hydrogeochemistry and } \\
\text { hydrology of Rainier Mesa. Desert Research Institute } \\
\text { Publication } 45046\end{array}$ \\
\hline U12n.03 Drift & Free Flowing Seep & 4/5/1985 & 6.6 & & $\begin{array}{l}\text { C.E. Russell, 1987. Hydrogeologic Investigation of Flow in } \\
\text { Fractured Tuffs, Rainier Mesa, Nevada Test Site. University of } \\
\text { Nevada, Las Vegas Master Thesis, } 154 \text { p. }\end{array}$ \\
\hline U12n.03 Drift & Free Flowing Seep & 5/10/1985 & 6.7 & & $\begin{array}{l}\text { C.E. Russell, 1987. Hydrogeologic Investigation of Flow in } \\
\text { Fractured Tuffs, Rainier Mesa, Nevada Test Site. University of } \\
\text { Nevada, Las Vegas Master Thesis, } 154 \text { p. }\end{array}$ \\
\hline
\end{tabular}


APPENDIX for Report: Review and Evaluation of Rainier Mesa Chloride Data for a Chloride Mass-Balance Infiltration Model. Chloride data recommended for use in a chloride mass balance infiltration model (continued).

\begin{tabular}{|c|c|c|c|c|c|}
\hline $\begin{array}{c}\text { Sample Location } \\
\text { Name } \\
\end{array}$ & Type of Sample & $\begin{array}{c}\text { Date Sample } \\
\text { was Collected }\end{array}$ & $\begin{array}{c}\mathrm{Cl} \\
\mathrm{mg} / \mathrm{l}\end{array}$ & Comment & Citation \\
\hline U12n.03 Drift & Free Flowing Seep & 3/30/1986 & 6.7 & & $\begin{array}{l}\text { C.E. Russell, 1987. Hydrogeologic Investigation of Flow in } \\
\text { Fractured Tuffs, Rainier Mesa, Nevada Test Site. University of } \\
\text { Nevada, Las Vegas Master Thesis, } 154 \text { p. }\end{array}$ \\
\hline U12n.03 Drift & Free Flowing Seep & 5/9/1986 & 6.6 & & $\begin{array}{l}\text { C.E. Russell, 1987. Hydrogeologic Investigation of Flow in } \\
\text { Fractured Tuffs, Rainier Mesa, Nevada Test Site. University of } \\
\text { Nevada, Las Vegas Master Thesis, } 154 \text { p. }\end{array}$ \\
\hline U12n.03 Drift 20+50 & Free Flowing Seep & 4/3/1980 & 9.1 & $\begin{array}{l}\text { Seep analyses taken } \\
\text { in support of } \\
\text { lysimeter study. Not } \\
\text { all lysimeter data } \\
\text { was used }\end{array}$ & $\begin{array}{l}\text { Jacobson, R.L., M.S. Henne, and J.W. Hess. 1986. A } \\
\text { reconnaissance investigation of hydrogeochemistry and } \\
\text { hydrology of Rainier Mesa. Desert Research Institute } \\
\text { Publication } 45046\end{array}$ \\
\hline U12n.03 Drift 20+50 & Free Flowing Seep & 7/9/1980 & 8.4 & $\begin{array}{l}\text { Seep analyses taken } \\
\text { in support of } \\
\text { lysimeter study. Not } \\
\text { all lysimeter data } \\
\text { was used }\end{array}$ & $\begin{array}{l}\text { Jacobson, R.L., M.S. Henne, and J.W. Hess. 1986. A } \\
\text { reconnaissance investigation of hydrogeochemistry and } \\
\text { hydrology of Rainier Mesa. Desert Research Institute } \\
\text { Publication } 45046\end{array}$ \\
\hline U12n.03 Drift 20+50 & Free Flowing Seep & 8/6/1980 & 9.2 & $\begin{array}{l}\text { Seep analyses taken } \\
\text { in support of } \\
\text { lysimeter study. Not } \\
\text { all lysimeter data } \\
\text { was used }\end{array}$ & $\begin{array}{l}\text { Jacobson, R.L., M.S. Henne, and J.W. Hess. 1986. A } \\
\text { reconnaissance investigation of hydrogeochemistry and } \\
\text { hydrology of Rainier Mesa. Desert Research Institute } \\
\text { Publication } 45046\end{array}$ \\
\hline U12n.03 Drift 20+50 & Free Flowing Seep & 9/3/1980 & 9.6 & $\begin{array}{l}\text { Seep analyses taken } \\
\text { in support of } \\
\text { lysimeter study. Not } \\
\text { all lysimeter data } \\
\text { was used }\end{array}$ & $\begin{array}{l}\text { Jacobson, R.L., M.S. Henne, and J.W. Hess. 1986. A } \\
\text { reconnaissance investigation of hydrogeochemistry and } \\
\text { hydrology of Rainier Mesa. Desert Research Institute } \\
\text { Publication } 45046\end{array}$ \\
\hline
\end{tabular}


APPENDIX for Report: Review and Evaluation of Rainier Mesa Chloride Data for a Chloride Mass-Balance Infiltration Model. Chloride data recommended for use in a chloride mass balance infiltration model (continued).

\begin{tabular}{|c|c|c|c|c|c|}
\hline $\begin{array}{c}\text { Sample Location } \\
\text { Name }\end{array}$ & Type of Sample & $\begin{array}{c}\text { Date Sample } \\
\text { was Collected }\end{array}$ & $\begin{array}{c}\mathrm{Cl} \\
\mathrm{mg} / \mathrm{l}\end{array}$ & Comment & Citation \\
\hline U12n.03 21+62 & tunnel - CLEAR; & 9/30/1966 & 9.6 & seep & $\begin{array}{l}\text { Perfect, D.L., C.C. Faunt, W.C. Steinkampf, and A. K. Turner. } \\
\text { 1994. Hydrochemical Data Base for the Death Valley Region, } \\
\text { California and Nevada. USGS Open-'File Report 94-305. }\end{array}$ \\
\hline U12n.05 Bypass Drift & Free Flowing Seep & 7/9/1980 & 7.3 & $\begin{array}{l}\text { Seep analyses taken } \\
\text { in support of } \\
\text { lysimeter study. Not } \\
\text { all lysimeter data } \\
\text { was used }\end{array}$ & $\begin{array}{l}\text { Jacobson, R.L., M.S. Henne, and J.W. Hess. 1986. A } \\
\text { reconnaissance investigation of hydrogeochemistry and } \\
\text { hydrology of Rainier Mesa. Desert Research Institute } \\
\text { Publication } 45046\end{array}$ \\
\hline U12n.05 Bypass Drift & Free Flowing Seep & 8/6/1980 & 7.8 & $\begin{array}{l}\text { Seep analyses taken } \\
\text { in support of } \\
\text { lysimeter study. Not } \\
\text { all lysimeter data } \\
\text { was used }\end{array}$ & $\begin{array}{l}\text { Jacobson, R.L., M.S. Henne, and J.W. Hess. 1986. A } \\
\text { reconnaissance investigation of hydrogeochemistry and } \\
\text { hydrology of Rainier Mesa. Desert Research Institute } \\
\text { Publication } 45046\end{array}$ \\
\hline U12n.05 Bypass Drift & Free Flowing Seep & 9/3/1980 & 7.9 & $\begin{array}{l}\text { Seep analyses taken } \\
\text { in support of } \\
\text { lysimeter study. Not } \\
\text { all lysimeter data } \\
\text { was used }\end{array}$ & $\begin{array}{l}\text { Jacobson, R.L., M.S. Henne, and J.W. Hess. 1986. A } \\
\text { reconnaissance investigation of hydrogeochemistry and } \\
\text { hydrology of Rainier Mesa. Desert Research Institute } \\
\text { Publication } 45046\end{array}$ \\
\hline U12n.05 Bypass Drift & Free Flowing Seep & 4/7/1986 & 8.4 & $\begin{array}{l}\text { Ionic Samples appear } \\
\text { to be improperly } \\
\text { labeled as } 03 \\
\text { samples. Evidence } \\
\text { in the report } \\
\text { indicates they are } \\
\text { most probably } 05 \\
\text { drift samples }\end{array}$ & $\begin{array}{l}\text { C.E. Russell, 1987. Hydrogeologic Investigation of Flow in } \\
\text { Fractured Tuffs, Rainier Mesa, Nevada Test Site. University of } \\
\text { Nevada, Las Vegas Master Thesis, } 154 \text { p. }\end{array}$ \\
\hline
\end{tabular}




\section{APPENDIX for Report: Review and Evaluation of Rainier Mesa Chloride Data for a Chloride Mass-Balance Infiltration Model. Chloride data recommended for use in a chloride mass balance infiltration model (continued).}

\begin{tabular}{|c|c|c|c|c|c|}
\hline $\begin{array}{l}\text { Sample Location } \\
\text { Name }\end{array}$ & Type of Sample & $\begin{array}{c}\text { Date Sample } \\
\text { was } \\
\text { Collected } \\
\end{array}$ & $\begin{array}{c}\mathrm{Cl} \\
\mathrm{mg} / \mathrm{l}\end{array}$ & Comment & Citation \\
\hline U12n.05 Bypass Drift & Free Flowing Seep & $5 / 12 / 1986$ & 8.8 & $\begin{array}{l}\text { Ionic Samples appear to } \\
\text { be improperly labeled } \\
\text { as } 03 \text { samples. } \\
\text { Evidence in the report } \\
\text { indicates they are most } \\
\text { probably } 05 \text { drift } \\
\text { samples }\end{array}$ & $\begin{array}{l}\text { C.E. Russell, 1987. Hydrogeologic Investigation of Flow in } \\
\text { Fractured Tuffs, Rainier Mesa, Nevada Test Site. University of } \\
\text { Nevada, Las Vegas Master Thesis, } 154 \text { p. }\end{array}$ \\
\hline $\begin{array}{l}\text { U12n. } 05 \text { bypass } \\
16+00\end{array}$ & Fault & $6 / 2 / 1971$ & 5.5 & seep & $\begin{array}{l}\text { Perfect, D.L., C.C. Faunt, W.C. Steinkampf, and A. K. Turner. } \\
\text { 1994. Hydrochemical Data Base for the Death Valley Region, } \\
\text { California and Nevada. USGS Open-'File Report 94-305. }\end{array}$ \\
\hline $\begin{array}{l}\text { U12n.05 STATION } \\
21+39\end{array}$ & $\begin{array}{l}\text { Fracture - WATER FROM } \\
\text { DRIPS FROM FRACTURES } \\
\text { IN TUNNEL BACK }\end{array}$ & 9/21/1971 & 13 & seep & $\begin{array}{l}\text { Perfect, D.L., C.C. Faunt, W.C. Steinkampf, and A. K. Turner. } \\
\text { 1994. Hydrochemical Data Base for the Death Valley Region, } \\
\text { California and Nevada. USGS Open-'File Report 94-305. }\end{array}$ \\
\hline $\begin{array}{l}\text { U12n.05 STATION } \\
21+44\end{array}$ & $\begin{array}{l}\text { Fractures - WATER DRIPS } \\
\text { FROM FRACTURES IN } \\
\text { TUNNEL BACK BEHIND } \\
\text { LAGGING-SAMPLE } \\
\text { CLEAR }\end{array}$ & 9/21/1971 & 13 & seep & $\begin{array}{l}\text { Perfect, D.L., C.C. Faunt, W.C. Steinkampf, and A. K. Turner. } \\
\text { 1994. Hydrochemical Data Base for the Death Valley Region, } \\
\text { California and Nevada. USGS Open-'File Report 94-305. }\end{array}$ \\
\hline U12n. 07 bypass $4+94$ & $\begin{array}{l}\text { Tunnel? - TV, ZEOLITIZED } \\
\text { BEDDED TUFF }\end{array}$ & 8/3/1972 & 2 & seep & $\begin{array}{l}\text { Perfect, D.L., C.C. Faunt, W.C. Steinkampf, and A. K. Turner. } \\
\text { 1994. Hydrochemical Data Base for the Death Valley Region, } \\
\text { California and Nevada. USGS Open-'File Report 94-305. }\end{array}$ \\
\hline U12n.07 bypass $4+94$ & Tunnel Wall & $11 / 14 / 1972$ & 2.13 & seep & $\begin{array}{l}\text { Perfect, D.L., C.C. Faunt, W.C. Steinkampf, and A. K. Turner. } \\
\text { 1994. Hydrochemical Data Base for the Death Valley Region, } \\
\text { California and Nevada. USGS Open-'File Report 94-305. }\end{array}$ \\
\hline $\begin{array}{l}\text { U12t Tunnel Gas Seal } \\
\text { door }\end{array}$ & seep & 4/3/1980 & 12 & $\begin{array}{l}\text { Seep analyses taken in } \\
\text { support of lysimeter }\end{array}$ & $\begin{array}{l}\text { Jacobson, R.L., M.S. Henne, and J.W. Hess. 1986. A reconnaissance } \\
\text { investigation of hydrogeochemistry and hydrology of Rainier Mesa. }\end{array}$ \\
\hline
\end{tabular}




\section{APPENDIX for Report: Review and Evaluation of Rainier Mesa Chloride Data for a Chloride Mass-Balance Infiltration Model. Chloride data recommended for use in a chloride mass balance infiltration model (continued).}

\begin{tabular}{|c|c|c|c|c|c|}
\hline $\begin{array}{c}\text { Sample Location } \\
\text { Name } \\
\end{array}$ & Type of Sample & $\begin{array}{c}\text { Date Sample } \\
\text { was Collected }\end{array}$ & $\begin{array}{c}\mathrm{Cl} \\
\mathrm{mg} / \mathrm{l}\end{array}$ & Comment & Citation \\
\hline & & & & $\begin{array}{l}\text { study. Not all } \\
\text { lysimeter data was used }\end{array}$ & Desert Research Institute Publication 45046 \\
\hline $\begin{array}{l}\text { U12t Tunnel Gas Seal } \\
\text { door }\end{array}$ & seep & 7/9/1980 & 11 & $\begin{array}{l}\text { Seep analyses taken in } \\
\text { support of lysimeter } \\
\text { study. Not all } \\
\text { lysimeter data was used }\end{array}$ & $\begin{array}{l}\text { Jacobson, R.L., M.S. Henne, and J.W. Hess. 1986. A reconnaissance } \\
\text { investigation of hydrogeochemistry and hydrology of Rainier Mesa. } \\
\text { Desert Research Institute Publication } 45046\end{array}$ \\
\hline $\begin{array}{l}\text { U12t Tunnel Gas Seal } \\
\text { door }\end{array}$ & seep & 9/3/1980 & 11.1 & $\begin{array}{l}\text { Seep analyses taken in } \\
\text { support of lysimeter } \\
\text { study. Not all } \\
\text { lysimeter data was used }\end{array}$ & $\begin{array}{l}\text { Jacobson, R.L., M.S. Henne, and J.W. Hess. 1986. A reconnaissance } \\
\text { investigation of hydrogeochemistry and hydrology of Rainier Mesa. } \\
\text { Desert Research Institute Publication } 45046\end{array}$ \\
\hline $\begin{array}{l}\text { U12t main drift } \\
17+22\end{array}$ & Tunnel Wall & 2/10/1975 & 12.2 & seep & $\begin{array}{l}\text { Perfect, D.L., C.C. Faunt, W.C. Steinkampf, and A. K. Turner. } 1994 . \\
\text { Hydrochemical Data Base for the Death Valley Region, California } \\
\text { and Nevada. USGS Open-'File Report 94-305. }\end{array}$ \\
\hline $\begin{array}{l}\text { TUNNEL T } \\
\text { STATION 32+00 }\end{array}$ & $\begin{array}{l}\text { Tunnel - NITRATE }>100 \\
\text { MG/L, SAMPLE SLI } \\
\text { CLOUDY }\end{array}$ & $10 / 7 / 1968$ & 8.8 & seep & $\begin{array}{l}\text { Perfect, D.L., C.C. Faunt, W.C. Steinkampf, and A. K. Turner. } 1994 . \\
\text { Hydrochemical Data Base for the Death Valley Region, California } \\
\text { and Nevada. USGS Open-'File Report 94-305. }\end{array}$ \\
\hline $\begin{array}{l}\text { U12t.02 main drift } \\
18+05\end{array}$ & Tunnel Wall & $4 / 10 / 1971$ & 11 & seep & $\begin{array}{l}\text { Perfect, D.L., C.C. Faunt, W.C. Steinkampf, and A. K. Turner. } 1994 . \\
\text { Hydrochemical Data Base for the Death Valley Region, California } \\
\text { and Nevada. USGS Open-'File Report 94-305. }\end{array}$ \\
\hline $\begin{array}{l}\text { U12t.02 main drift } \\
18+05\end{array}$ & $\begin{array}{l}\text { Fractures - WTR DRIPS } \\
\text { FROM FRACTURES } \\
\text { BEHIND LAGGING- } \\
\text { CLEAR, WITH ALGAE OR } \\
\text { MOSS LICHEN }\end{array}$ & 9/22/1971 & 10 & seep & $\begin{array}{l}\text { Perfect, D.L., C.C. Faunt, W.C. Steinkampf, and A. K. Turner. } 1994 . \\
\text { Hydrochemical Data Base for the Death Valley Region, California } \\
\text { and Nevada. USGS Open-'File Report 94-305. }\end{array}$ \\
\hline $\begin{array}{l}\text { U12t.02 main drift } \\
18+05\end{array}$ & $\begin{array}{l}\text { Tunnel - TV, ZEOLITIZED } \\
\text { BEDDED TUFF IN } \\
\text { TUNNEL BED }\end{array}$ & 7/31/1972 & 11 & seep & $\begin{array}{l}\text { Perfect, D.L., C.C. Faunt, W.C. Steinkampf, and A. K. Turner. } 1994 . \\
\text { Hydrochemical Data Base for the Death Valley Region, California } \\
\text { and Nevada. USGS Open-'File Report 94-305. }\end{array}$ \\
\hline
\end{tabular}


APPENDIX for Report: Review and Evaluation of Rainier Mesa Chloride Data for a Chloride Mass-Balance Infiltration Model. Chloride data recommended for use in a chloride mass balance infiltration model (continued).

\begin{tabular}{|c|c|c|c|c|c|}
\hline $\begin{array}{c}\text { Sample Location } \\
\text { Name } \\
\end{array}$ & Type of Sample & $\begin{array}{c}\text { Date Sample } \\
\text { was Collected }\end{array}$ & $\begin{array}{c}\mathrm{Cl} \\
\mathrm{mg} / \mathrm{l}\end{array}$ & Comment & Citation \\
\hline $\begin{array}{l}\text { U12t.02 main drift } \\
18+05\end{array}$ & $\begin{array}{l}\text { Tunnel - CLEAR, } \\
\text { ZEOLITIZED BEDDED } \\
\text { TUFF IN TUNNEL BED 2B } \\
\text { IN INDIAN TRAIL FM }\end{array}$ & 11/15/1972 & 12 & seep & $\begin{array}{l}\text { Perfect, D.L., C.C. Faunt, W.C. Steinkampf, and A. K. Turner. } 1994 . \\
\text { Hydrochemical Data Base for the Death Valley Region, California } \\
\text { and Nevada. USGS Open-'File Report 94-305. }\end{array}$ \\
\hline $\begin{array}{l}\text { U12t.02 main drift } \\
18+05\end{array}$ & Tunnel - CLEAR & 11/20/1972 & 13 & seep & $\begin{array}{l}\text { Perfect, D.L., C.C. Faunt, W.C. Steinkampf, and A. K. Turner. } 1994 . \\
\text { Hydrochemical Data Base for the Death Valley Region, California } \\
\text { and Nevada. USGS Open-'File Report 94-305. }\end{array}$ \\
\hline $\begin{array}{l}\text { U12t.02 BYPASS } \\
6+50\end{array}$ & Tunnel Wall & 9/22/1971 & 1.78 & seep & $\begin{array}{l}\text { Perfect, D.L., C.C. Faunt, W.C. Steinkampf, and A. K. Turner. } 1994 . \\
\text { Hydrochemical Data Base for the Death Valley Region, California } \\
\text { and Nevada. USGS Open-'File Report 94-305. }\end{array}$ \\
\hline $\begin{array}{l}\text { U12t.02 BYPASS } \\
\text { DRIFT AT ST } 6+50\end{array}$ & $\begin{array}{l}\text { Fractures - WATER DRIPS } \\
\text { FROM FRACTURES IN } \\
\text { TUNNEL BACK BEHIND } \\
\text { LAGGING-SAMPLE } \\
\text { CLEAR }\end{array}$ & 9/22/1971 & 1.8 & seep & $\begin{array}{l}\text { Perfect, D.L., C.C. Faunt, W.C. Steinkampf, and A. K. Turner. } 1994 . \\
\text { Hydrochemical Data Base for the Death Valley Region, California } \\
\text { and Nevada. USGS Open-'File Report 94-305. }\end{array}$ \\
\hline $\begin{array}{l}\text { U12t.02 by pass } \\
19+65\end{array}$ & $\begin{array}{l}\text { Fractures - WATER DRIPS } \\
\text { FROM TUNNEL } \\
\text { FRACTURES TUNNEL } \\
\text { BACK-SLIGHT YELLOW } \\
\text { CAST }\end{array}$ & 9/22/1971 & 1.8 & seep & $\begin{array}{l}\text { Perfect, D.L., C.C. Faunt, W.C. Steinkampf, and A. K. Turner. } 1994 . \\
\text { Hydrochemical Data Base for the Death Valley Region, California } \\
\text { and Nevada. USGS Open-'File Report 94-305. }\end{array}$ \\
\hline U12t.02 x-cut\#2 & Fractures & 9/22/1971 & 1.6 & seep & $\begin{array}{l}\text { Perfect, D.L., C.C. Faunt, W.C. Steinkampf, and A. K. Turner. } 1994 . \\
\text { Hydrochemical Data Base for the Death Valley Region, California } \\
\text { and Nevada. USGS Open-'File Report 94-305. }\end{array}$ \\
\hline U12t.03 1+37 & TUNNEL WALL & 2/4/1975 & 11 & seep & $\begin{array}{l}\text { Perfect, D.L., C.C. Faunt, W.C. Steinkampf, and A. K. Turner. } 1994 . \\
\text { Hydrochemical Data Base for the Death Valley Region, California } \\
\text { and Nevada. USGS Open-'File Report 94-305. }\end{array}$ \\
\hline
\end{tabular}


APPENDIX for Report: Review and Evaluation of Rainier Mesa Chloride Data for a Chloride Mass-Balance Infiltration Model. Chloride data recommended for use in a chloride mass balance infiltration model (continued).

\begin{tabular}{|c|c|c|c|c|c|}
\hline $\begin{array}{c}\text { Sample Location } \\
\text { Name } \\
\end{array}$ & Type of Sample & $\begin{array}{c}\text { Date Sample } \\
\text { was Collected } \\
\end{array}$ & $\begin{array}{c}\mathrm{Cl} \\
\mathrm{mg} / \mathrm{l}\end{array}$ & Comment & Citation \\
\hline U12t.03 1+37 & TUNNEL WALL & $2 / 10 / 1975$ & 10.8 & seep & $\begin{array}{l}\text { Perfect, D.L., C.C. Faunt, W.C. Steinkampf, and A. K. Turner. } 1994 . \\
\text { Hydrochemical Data Base for the Death Valley Region, California } \\
\text { and Nevada. USGS Open-'File Report 94-305. }\end{array}$ \\
\hline U12t.03 work point & TUNNEL WALL & & 10 & seep & $\begin{array}{l}\text { Perfect, D.L., C.C. Faunt, W.C. Steinkampf, and A. K. Turner. } 1994 . \\
\text { Hydrochemical Data Base for the Death Valley Region, California } \\
\text { and Nevada. USGS Open-'File Report 94-305. }\end{array}$ \\
\hline \multicolumn{6}{|l|}{ SPRINGS } \\
\hline $\begin{array}{l}\text { CAPTAIN JACK } \\
\text { SPRINGS }\end{array}$ & $\begin{array}{l}\text { Spring - SLIGHTLY } \\
\text { MILKY; }\end{array}$ & $5 / 1 / 1959$ & 4 & spring & $\begin{array}{l}\text { Perfect, D.L., C.C. Faunt, W.C. Steinkampf, and A. K. Turner. } 1994 . \\
\text { Hydrochemical Data Base for the Death Valley Region, California } \\
\text { and Nevada. USGS Open-'File Report 94-305. }\end{array}$ \\
\hline $\begin{array}{l}\text { CAPTAIN JACK } \\
\text { SPRINGS }\end{array}$ & & 8/2/1991 & 4.8 & spring & $\begin{array}{l}\text { Perfect, D.L., C.C. Faunt, W.C. Steinkampf, and A. K. Turner. } 1994 . \\
\text { Hydrochemical Data Base for the Death Valley Region, California } \\
\text { and Nevada. USGS Open-'File Report 94-305. }\end{array}$ \\
\hline $\begin{array}{l}\text { WHITEROCK } \\
\text { SPRING }\end{array}$ & Spring - CLEAR & 4/5/1957 & 11 & spring & $\begin{array}{l}\text { Perfect, D.L., C.C. Faunt, W.C. Steinkampf, and A. K. Turner. } 1994 . \\
\text { Hydrochemical Data Base for the Death Valley Region, California } \\
\text { and Nevada. USGS Open-'File Report 94-305. }\end{array}$ \\
\hline $\begin{array}{l}\text { WHITEROCK } \\
\text { SPRING }\end{array}$ & Spring - MILKY & 9/18/1957 & 8 & spring & $\begin{array}{l}\text { Perfect, D.L., C.C. Faunt, W.C. Steinkampf, and A. K. Turner. } 1994 . \\
\text { Hydrochemical Data Base for the Death Valley Region, California } \\
\text { and Nevada. USGS Open-'File Report 94-305. }\end{array}$ \\
\hline $\begin{array}{l}\text { WHITEROCK } \\
\text { SPRING }\end{array}$ & Spring - MILKY & 3/21/1958 & 6 & spring & $\begin{array}{l}\text { Perfect, D.L., C.C. Faunt, W.C. Steinkampf, and A. K. Turner. } 1994 . \\
\text { Hydrochemical Data Base for the Death Valley Region, California } \\
\text { and Nevada. USGS Open-'File Report 94-305. }\end{array}$ \\
\hline $\begin{array}{l}\text { WHITEROCK } \\
\text { SPRING }\end{array}$ & $\begin{array}{l}\text { Spring - CLEAR; WATER IS } \\
\text { A MIXTURE OF EASTERN } \\
\text { \& SOUTHERN SEEPS }\end{array}$ & 5/19/1959 & 9 & spring & $\begin{array}{l}\text { Perfect, D.L., C.C. Faunt, W.C. Steinkampf, and A. K. Turner. } 1994 . \\
\text { Hydrochemical Data Base for the Death Valley Region, California } \\
\text { and Nevada. USGS Open-'File Report 94-305. }\end{array}$ \\
\hline
\end{tabular}




\section{APPENDIX for Report: Review and Evaluation of Rainier Mesa Chloride Data for a Chloride Mass-Balance Infiltration Model. Chloride data recommended for use in a chloride mass balance infiltration model (continued).}

\begin{tabular}{|c|c|c|c|c|c|}
\hline $\begin{array}{c}\text { Sample Location } \\
\text { Name } \\
\end{array}$ & Type of Sample & $\begin{array}{c}\text { Date Sample } \\
\text { was Collected }\end{array}$ & $\begin{array}{c}\mathrm{Cl} \\
\mathrm{mg} / \mathrm{l}\end{array}$ & Comment & Citation \\
\hline $\begin{array}{l}\text { WHITEROCK } \\
\text { SPRING }\end{array}$ & $\begin{array}{l}\text { Spring - CONTAINS } \\
\text { SEDIMENT, CLOUDY }\end{array}$ & $1 / 29 / 1960$ & 6 & spring & $\begin{array}{l}\text { Perfect, D.L., C.C. Faunt, W.C. Steinkampf, and A. K. Turner. } 1994 . \\
\text { Hydrochemical Data Base for the Death Valley Region, California } \\
\text { and Nevada. USGS Open-'File Report 94-305. }\end{array}$ \\
\hline $\begin{array}{l}\text { WHITEROCK } \\
\text { SPRING }\end{array}$ & $\begin{array}{l}\text { Spring - SLIGHTLY } \\
\text { TURBID; PO4 TOO HIGH }\end{array}$ & $11 / 10 / 1960$ & 6.5 & spring & $\begin{array}{l}\text { Perfect, D.L., C.C. Faunt, W.C. Steinkampf, and A. K. Turner. } 1994 . \\
\text { Hydrochemical Data Base for the Death Valley Region, California } \\
\text { and Nevada. USGS Open-'File Report 94-305. }\end{array}$ \\
\hline $\begin{array}{l}\text { WHITEROCK } \\
\text { SPRING }\end{array}$ & Spring - SAMPLE MILKY & $11 / 15 / 1971$ & 10 & spring & $\begin{array}{l}\text { Perfect, D.L., C.C. Faunt, W.C. Steinkampf, and A. K. Turner. } 1994 . \\
\text { Hydrochemical Data Base for the Death Valley Region, California } \\
\text { and Nevada. USGS Open-'File Report 94-305. }\end{array}$ \\
\hline $\begin{array}{l}\text { WHITEROCK } \\
\text { SPRING }\end{array}$ & Spring - SAMPLE MILKY & $4 / 10 / 1972$ & 11 & spring & $\begin{array}{l}\text { Perfect, D.L., C.C. Faunt, W.C. Steinkampf, and A. K. Turner. } 1994 . \\
\text { Hydrochemical Data Base for the Death Valley Region, California } \\
\text { and Nevada. USGS Open-'File Report 94-305. }\end{array}$ \\
\hline $\begin{array}{l}\text { WHITEROCK } \\
\text { SPRING }\end{array}$ & $\begin{array}{l}\text { Creek - FROM RUNOFF 50' } \\
\text { NE OF (ABOVE) WHITE } \\
\text { ROCK SPRING }\end{array}$ & 3/14/1973 & 3.7 & creek & $\begin{array}{l}\text { Perfect, D.L., C.C. Faunt, W.C. Steinkampf, and A. K. Turner. } 1994 . \\
\text { Hydrochemical Data Base for the Death Valley Region, California } \\
\text { and Nevada. USGS Open-'File Report 94-305. }\end{array}$ \\
\hline $\begin{array}{l}\text { WHITEROCK } \\
\text { SPRING }\end{array}$ & Creek & 3/14/1973 & 3.5 & creek & $\begin{array}{l}\text { Perfect, D.L., C.C. Faunt, W.C. Steinkampf, and A. K. Turner. } 1994 . \\
\text { Hydrochemical Data Base for the Death Valley Region, California } \\
\text { and Nevada. USGS Open-'File Report 94-305. }\end{array}$ \\
\hline $\begin{array}{l}\text { WHITEROCK } \\
\text { SPRING }\end{array}$ & & 3/14/1973 & 8.5 & spring & $\begin{array}{l}\text { Perfect, D.L., C.C. Faunt, W.C. Steinkampf, and A. K. Turner. } 1994 . \\
\text { Hydrochemical Data Base for the Death Valley Region, California } \\
\text { and Nevada. USGS Open-'File Report 94-305. }\end{array}$ \\
\hline $\begin{array}{l}\text { WHITEROCK } \\
\text { SPRING }\end{array}$ & spring - MILKY & 11/15/1972 & 9.2 & spring & $\begin{array}{l}\text { Perfect, D.L., C.C. Faunt, W.C. Steinkampf, and A. K. Turner. } 1994 . \\
\text { Hydrochemical Data Base for the Death Valley Region, California } \\
\text { and Nevada. USGS Open-'File Report 94-305. }\end{array}$ \\
\hline
\end{tabular}


APPENDIX for Report: Review and Evaluation of Rainier Mesa Chloride Data for a Chloride Mass-Balance Infiltration Model. Chloride data recommended for use in a chloride mass balance infiltration model (continued).

\begin{tabular}{|c|c|c|c|c|c|}
\hline $\begin{array}{c}\text { Sample Location } \\
\text { Name } \\
\end{array}$ & Type of Sample & $\begin{array}{c}\text { Date Sample } \\
\text { was Collected }\end{array}$ & $\begin{array}{c}\mathrm{Cl} \\
\mathrm{mg} / \mathrm{l}\end{array}$ & Comment & Citation \\
\hline $\begin{array}{l}\text { WHITEROCK } \\
\text { SPRING }\end{array}$ & & $11 / 15 / 1972$ & 3.5 & spring & $\begin{array}{l}\text { Perfect, D.L., C.C. Faunt, W.C. Steinkampf, and A. K. Turner. } 1994 . \\
\text { Hydrochemical Data Base for the Death Valley Region, California } \\
\text { and Nevada. USGS Open-'File Report 94-305. }\end{array}$ \\
\hline $\begin{array}{l}\text { WHITEROCK } \\
\text { SPRING }\end{array}$ & & 8/2/1991 & 13 & creek & $\begin{array}{l}\text { Perfect, D.L., C.C. Faunt, W.C. Steinkampf, and A. K. Turner. } 1994 . \\
\text { Hydrochemical Data Base for the Death Valley Region, California } \\
\text { and Nevada. USGS Open-'File Report 94-305. }\end{array}$ \\
\hline $\begin{array}{l}\text { WHITEROCK } \\
\text { SPRING }\end{array}$ & spring - MILKY & 7/31/1972 & 10 & spring & $\begin{array}{l}\text { Perfect, D.L., C.C. Faunt, W.C. Steinkampf, and A. K. Turner. } 1994 . \\
\text { Hydrochemical Data Base for the Death Valley Region, California } \\
\text { and Nevada. USGS Open-'File Report 94-305. }\end{array}$ \\
\hline RAINIER SPRING & Spring MUDDY; & 9/18/1957 & 14 & spring & $\begin{array}{l}\text { Perfect, D.L., C.C. Faunt, W.C. Steinkampf, and A. K. Turner. } 1994 . \\
\text { Hydrochemical Data Base for the Death Valley Region, California } \\
\text { and Nevada. USGS Open-'File Report 94-305. }\end{array}$ \\
\hline \multicolumn{6}{|l|}{ WELLS } \\
\hline HAGESTAD & well & 9/17/1957 & 8 & Well & $\begin{array}{l}\text { Perfect, D.L., C.C. Faunt, W.C. Steinkampf, and A. K. Turner. } 1994 . \\
\text { Hydrochemical Data Base for the Death Valley Region, California } \\
\text { and Nevada. USGS Open-'File Report 94-305 and Clebsch, A. } 1960 . \\
\text { Analyses of Groundwater From Rainier Mesa, Nevada Test Sit }\end{array}$ \\
\hline HAGESTAD & well - CLOUDY; CSE TD & $4 / 23 / 1958$ & 5 & Well & $\begin{array}{l}\text { Perfect, D.L., C.C. Faunt, W.C. Steinkampf, and A. K. Turner. } 1994 . \\
\text { Hydrochemical Data Base for the Death Valley Region, California } \\
\text { and Nevada. USGS Open-'File Report 94-305. and Ege, J.R., R.D. } \\
\text { Carroll, J.E. Magner, and D.R. Cunningham. 1980. U.S. Geologic } \\
\text { Survey }\end{array}$ \\
\hline HAGESTAD & $\begin{array}{l}\text { well - SAMPLE IS SOAPY; } \\
\text { CSE TD }\end{array}$ & $12 / 10 / 1958$ & 9 & Well & $\begin{array}{l}\text { Perfect, D.L., C.C. Faunt, W.C. Steinkampf, and A. K. Turner. } 1994 . \\
\text { Hydrochemical Data Base for the Death Valley Region, California } \\
\text { and Nevada. USGS Open-'File Report 94-305. }\end{array}$ \\
\hline
\end{tabular}

